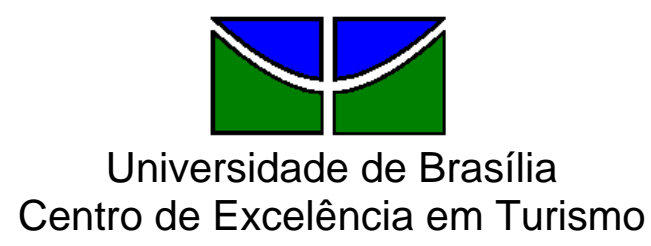

Pós-graduação Lato Sensu

Curso de Especialização em Gestão de Negócios em Turismo

\title{
PRÁTICAS DE GESTÃO DE PESSOAS NO SETOR HOTELEIRO DE JUIZ DE FORA-MG
}

Frederico Azevedo Alvim Assis

Brasília - 2009 


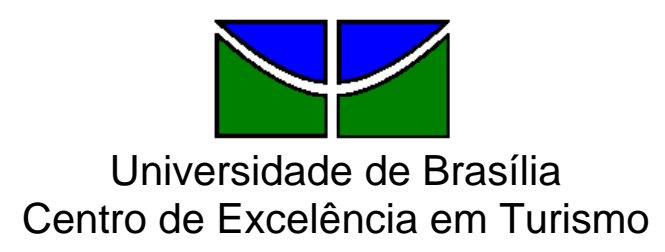

Pós-graduação Lato Sensu

Curso de Especialização em Gestão de Negócios em Turismo

\section{PRÁTICAS DE GESTÃO DE PESSOAS NO SETOR HOTELEIRO DE JUIZ DE FORA-MG}

Frederico Azevedo Alvim Assis

Professor Orientador: Mac Amaral Cartaxo (Msc.)

Monografia apresentada ao Centro de Excelência em Turismo da Universidade de Brasília - CET/UnB, como requisito parcial à obtenção do grau de Especialista em Gestão de Negócios em Turismo. 


\title{
PRÁTICAS DE GESTÃO DE PESSOAS NO SETOR HOTELEIRO DE JUIZ DE FORA-MG
}

\author{
Frederico Azevedo Alvim Assis
}

Aprovado por:

Professor orientador: Mac Amaral Cartaxo, Msc.

Professor Avaliador: Domingos Spezia, Msc.

Professor Avaliador: Walter Ribeiro, Msc. 
À minha mãe, que sempre me permitiu confiar nos meus próprios objetivos - até mesmo aqueles que não evidenciavam lógicas aparentes. 
Agradeço aos meus tios Maria de Jesus Coelho Alvim Bilemjian e Reinaldo Brazil Bilemjian, por abrirem as portas de sua residência, me hospedando, com especial carinho, durante todo o período das aulas do curso de pós-graduação lato sensu em Gestão de Negócios em Turismo na Universidade de Brasília; certamente a experiência de viver na capital federal não teria sido tão segura sem a presença deles. Agradeço à minha prima Mariane Alvim Bilemjian, pela amizade e companheirismo que sempre me conduziram às mais instigantes reflexões; ao Daniel Alvim Bilemjian, Raissa de Sá e Benevides N. Costa, e Letícia de Sá e Benevides Bilemjian, pelo protagonismo que desempenham na alegria da minha família. E, por fim, agradeço a Deus por ter me inserido neste contexto familiar, composto por personalidades tão fascinantes, cuja admiração haverá de sempre me orientar para gratificantes realizações. 


\section{RESUMO}

A presente pesquisa teve objetivo identificar quais são as atividades de Gestão de Pessoas realizadas para promoverem o diferencial estratégico das organizações que integram o setor hoteleiro da cidade de Juiz de Fora - MG. Este estudo se baseou em levantamentos bibliográficos e revisão de publicações acerca de teorias e conhecimentos próprios das áreas de Gestão de Pessoas e Hotelaria, de modo a enfatizar como essas duas áreas se correlacionam, ressaltando as possíveis contribuições da primeira à segunda. Além da revisão de literatura, foi realizada pesquisa de campo que consistiu em coleta de dados primários, ocorrida no período de 18 de abril de 2009 a 11 de junho de 2009, através de questionário estruturado aplicado à amostra de onze gerentes gerais de hotéis juizforanos. Os dados obtidos foram tabulados em planilhas, através do software Microsoft Excel, e convertidos em Tabelas e Gráficos que possibilitaram suas respectivas projeções e análises. Com base na determinação dos seguintes objetivos específicos: identificar as contribuições estratégicas da Gestão de Pessoas para a prestação dos serviços de hospedagem; analisar a importância do planejamento da Gestão de Pessoas; e comparar as principais práticas vigentes com as propostas e conteúdos pesquisados na literatura, foi elaborado o instrumento para coleta de dados, e definida a metodologia para orientar o desenvolvimento deste trabalho. Assim sendo, à luz das análises dos dados, correlacionadas a investigação acerca dos mencionados objetivos específicos, obteve-se as observações e argumentações que culminaram na consideração final de que os gerentes gerais dos hotéis pesquisados ainda não percebem a plenitude da Gestão de Pessoas como área organizacional determinante para a aquisição de diferenciais estratégicos e vantagens competitivas a uma organização hoteleira inserida no mercado do Turismo. 


\begin{abstract}
This research was to identify what are the activities of management of people had been taken to promote the spread of strategic organizations that form the hospitality of the city of Juiz de Fora - MG. This study was based on literature review and review of publications about the theories and knowledge of the areas of People Management and Hospitality, to emphasize how these two areas correlate, highlighting the possible contributions of the first to the second. Besides the literature review, field research was conducted which consisted of primary data collection, occurred in the period from 18 April 2009 to 11 June 2009, through a structured questionnaire applied to the sample of eleven general managers of hotels from Juiz de Fora. Data were tabulated on spreadsheets through Microsoft Excel software, and converted into tables and graphs that allowed their projections and analysis. Based on the determination of the following specific objectives: to identify the contributions of the strategic management of people to provide the hosting services, analyze the importance of planning the management of people and compare the practice with the main proposals in the literature search and content, the instrument was developed for data collection, and defined the methodology to guide the development of this work. Thus, in order of the data's analysis, related to research on the specific objectives mentioned, were obtained by the observations and arguments that culminated in the final consideration of the general managers of hotels surveyed still do not understand the fullness of the Management of People like an organizational area able to determined the differential acquisition of strategic and competitive advantages to an organization incorporated in the hotel market in tourism.
\end{abstract}

Keywords:
1. Management people
2 Hospitality
3. Hotel's manager 


\section{SUMÁRIO}

I - PERSPECTIVAS SOBRE A GESTÃO HOTELEIRA .04

1.1 Contextualização e elementos envolvidos nas práticas de gestão em hotelaria .04

1.2 Planejamento estratégico em Gestão Hoteleira .08

1.3 Classificações dos serviços e organizações hoteleiras .09

II - O CARGO DE GERENTE GERAL EM HOTELEIRA 12

2.1 Principais responsabilidades do cargo 15

2.2 Atribuições de liderança ao Gerente Geral de um hotel .16

2.3 Sobre a qualidade dos serviços de hospedagem .16

2.4 A motivação das equipes de trabalho como diferencial estratégico aos serviços de hospedagem 19

2.5 A Gerência Geral em Hotelaria como mediadora à promoção de inovações e de manifestações do potencial criativo de hoteliers.

III - PRÁTICAS DE GESTÃO DE PESSOAS EM HOTELARIA ..............24

3.1 Associações entre Gestão de Pessoas e Hotelaria 24

3.2 Práticas de gestão de pessoas em hotéis .28

3.2.1 Processos de comunicação interna num contexto organizacionalhoteleiro.

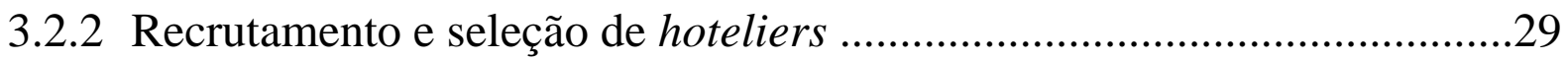

3.2.3 Descrição e Análise de Cargos nos hotéis .................................................33

3.2.4 O desenvolvimento de Carreiras para hoteliers .........................................35

3.2.5 Treinamento e Desenvolvimento em hotelaria ........................................36

3.2.6 Avaliações de Desempenho de hoteliers ..................................................39

3.2.7 Programas de Qualidade de Vida em organizações hoteleiras ..................41

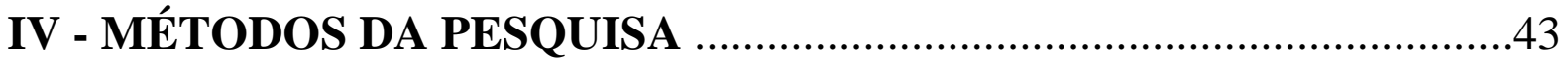

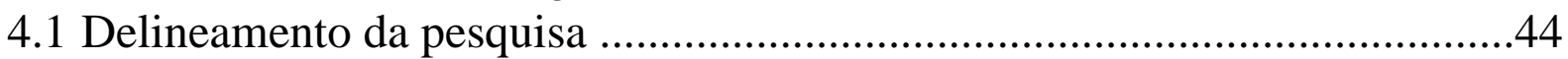

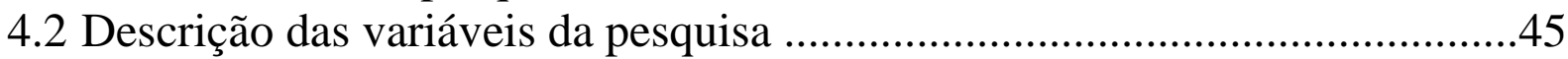

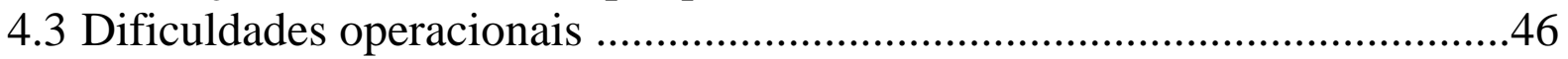

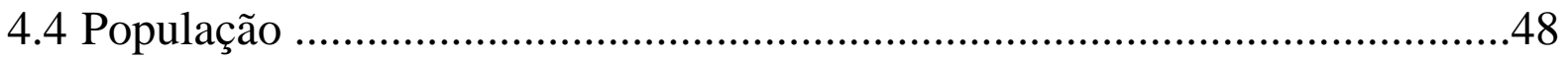

4.5 Procedimentos e instrumento utilizados na coleta e análise de

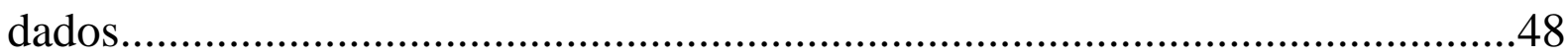

4.6 Período de realização da pesquisa ......................................................50

V - APRESENTAÇÃO E ANÁLISE DOS DADOS ......................................51 
5.1 Análise descritiva dos dados

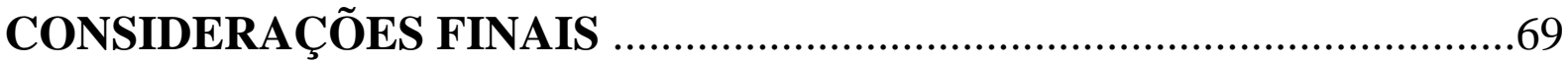

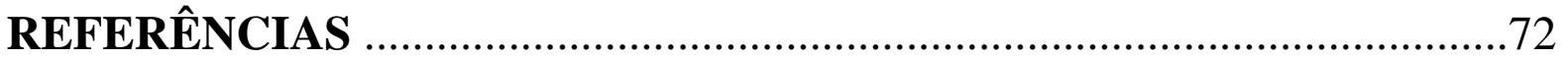

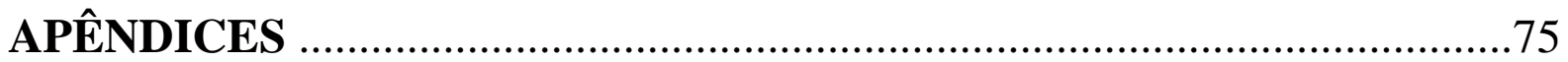

APÊNDICE A: Questionário utilizado para coleta de dados .......................75

APÊNDICE B: Modelo de e-mail enviado aos hotéis ..................................78

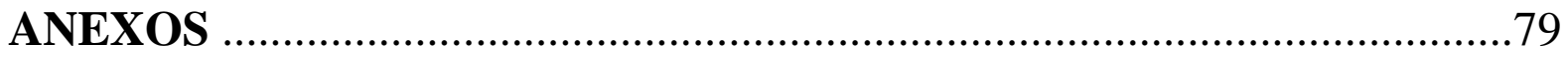

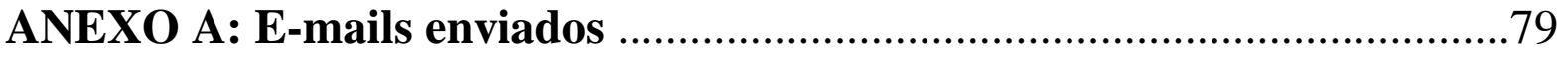




\section{LISTA DE ILUSTRAÇÕES}

Quadro 01: Elementos envolvidos em Gestão Hoteleira .07

Quadro 02: Classificação dos serviços de hospedagem, de acordo com autores pesquisados.

Quadro 03: Teorias sobre a motivação humana para o trabalho 20

Gráfico 01: Classificações dos serviços de hospedagem dos hotéis pesquisados .53

Gráfico 02: Existe setor/departamento de RH no hotel? .54

Gráfico 2.1: As atividades de RH no hotel se concentram em: 56

Gráfico 03: Como ocorrem processos de recrutamento e seleção nos hotéis pesquisados. 58

Gráfico 04: Há oportunidades de planos de carreiras nos hotéis pesquisados? .59

Gráfico 05: Os hoteliers recebem treinamentos?

Gráfico 06: Nos hotéis pesquisados, os programas de T\&D são: 63

Gráfico 07: São aplicadas avaliações de desempenho nos hotéis pesquisados? .64

Gráfico 08: Há descrição de cargos nos hotéis pesquisados? .65

Gráfico 09: A qualidade dos serviços de hospedagem é mensurada? .67

Gráfico 10: Nas perspectivas dos gerentes de hotéis: .68 


\section{LISTA DE TABELAS}

Tabela 01 - Qual é a classificação do hotel pesquisado, na perspectiva dos serviços de hospedagem que oferece?

Tabela 02 - Existe, no hotel gerenciado pelo(a) senhor(a), um departamento - ou setor próprio para práticas da área de Administração de Recursos Humanos, ou Gestão de Pessoas?

Tabela 2.1 - Se “sim”, as atividades desse departamento - ou setor - se concentram em:.

Tabela 03 - Geralmente, os processos de recrutamento e seleção no hotel, são:

Tabela 04 - Existem oportunidades para os hoteliers da organização desenvolverem plano de carreira?

Tabela 05 - Os hoteliers dessa organização recebem treinamentos .60

Tabela 06 - Os programas de T\&D, direcionados aos profissionais desse hotel, geralmente são:

Tabela 07 - São aplicadas avaliações de desempenho nesse hotel?

Tabela 08 - As práticas de Gestão de Pessoas, no hotel pesquisado, são orientadas de acordo com uma descrição de cargos, já desenvolvida? ..65

Tabela 09 - Existem ferramentas para a mensuração da qualidade na prestação de serviços oferecidos nesse hotel?

Tabela 10 - Na perspectiva dos gerentes gerais dos hotéis: 


\section{INTRODUÇÃO}

No cenário organizacional contemporâneo, a constante busca por diferenciais capazes de promover vantagens competitivas para uma empresa, frente à sua crescente concorrência, leva cada vez mais à preocupação sobre as variáveis humanas envolvidas nos processos organizacionais. É possível apontar que esse ideal também se aplica ao setor hoteleiro. E como não é possível estabelecer generalizações, o campo de investigação, abordada e desenvolvida nessa pesquisa, se limitou aos hotéis de Juiz de Fora, local identificado como atrativo turístico para fins de negócios (devido ao seu considerável número de indústrias, novas instituições de ensino superior, bem como aos recentes processos de expansão comercial vividos, nos últimos quatro anos, nessa cidade mineira), e de lazer (como resultado de eventos culturais e sociais que ocorrem nesse município).

Hoje, a cidade "Manchester Mineira” se caracteriza, regionalmente, pela expansão da prestação de serviços, tanto na área comercial quanto educacional, enquanto resultado do crescimento do número de instituições de ensino superior. Enfatiza-se que essa realidade implica na necessidade de utilização dos serviços oferecidos pelo setor hoteleiro, daí a relevância em investigar tal setor, especialmente no que tange às colaborações da gestão de pessoas.

A partir da premissa de que as pessoas no contexto de trabalho constituem elementos da promoção de crescimento organizacional, pressupõe-se que formar e desenvolver conhecimentos, habilidades e atitudes (variáveis comportamentais) dos funcionários de organizações hoteleiras representa os principais fatores capazes de tornar um hotel mais competitivo no cenário do Turismo.

Nessa perspectiva, a presente pesquisa teve por foco descrever como as práticas na área de Gestão de Pessoas - em hotéis sediados na cidade de Juiz de Fora, Minas Gerais podem contribuir para a gestão estratégica nessas organizações. Para tanto, definiu-se por objetivo desse estudo identificar quais são as atividades de Gestão de Pessoas realizadas para promoverem o diferencial estratégico da organização hoteleira.

Frente a esse desafio, partiu-se do interesse em se conhecer, descrever e refletir acerca de quais atividades de Gestão de Pessoas, no cotidiano dos hotéis de Juiz de Fora, capazes de promover diferenciais estratégicos, conduzindo à possibilidade de se analisar a importância do 
planejamento daquela área de conhecimento e prática organizacional ao sucesso de um empreendimento hoteleiro.

Por se tratar de um trabalho científico, outro foco de interesse, que se concentrou na determinação de objetivos específicos, consistiu na intenção de se comparar as principais práticas vigentes nos hotéis investigados com as propostas e conteúdos pesquisados na literatura. Para tanto, esse estudo se baseou em levantamentos bibliográficos e revisão de publicações acerca de teorias e conhecimentos próprios das áreas de Gestão de Pessoas e Hotelaria, de modo a não somente apresentar o que vem sendo produzido e publicado nos últimos anos, mas também enfatizar como aquelas duas áreas se correlacionam, ressaltando as possíveis contribuições da primeira à segunda.

A revisão de literatura, que constitui o "referencial teórico" desse trabalho, se estruturou na apresentação de abordagens sobre a gestão hoteleira (capítulo 1); o papel funcional dos gerentes gerais de hotéis e suas determinantes contribuições à delegação de tarefas para as equipes de profissionais que integram os quadros de funcionários efetivos de um hotel (capítulo 2); e nas associações entre o que é publicado na área de Gestão de Pessoas com os conhecimentos em Hotelaria (capítulo 3). Em seguida, são apresentados os métodos, instrumento, dados obtidos e analisados para fins de descrição de práticas cotidianas pertinentes ao contexto hoteleiro da cidade de Juiz de Fora e suas considerações à capacitação, valorização e emprego do capital humano nas organizações hoteleiras investigadas.

Com a finalidade de se comparar a realidade estudada com as propostas teóricas, bem como fomentar o conhecimento sobre o que é, de fato, praticado nos hotéis, o método para coleta de dados dessa pesquisa se concentrou na aplicação de um questionário estruturado, constituído por questões focadas às percepções sobre as práticas de gestão de pessoas. Esse instrumento foi aplicado aos gerentes gerais dos principais hotéis juizforanos. A opção por esse público se justifica pela premissa de que são os responsáveis pela administração geral de um empreendimento hoteleiro, assumindo a tarefa de comunicar, sob forma de estratégias e planos de ação a serem aplicados pelos funcionários, as expectativas dos proprietários e investidores de tal tipo de empreendimento.

Embora se tenha identificado o universo de vinte e quatro hotéis em Juiz de Fora, não foi possível obter a devida colaboração de todos, ainda que se tenha apresentado o 
questionário em todas aquelas organizações. Apenas onze gerentes se disponibilizaram à efetiva aplicação daquele instrumento.

A realização da pesquisa de campo (compreendida pela etapa de “coleta de dados”) ocorreu no período de 18 de abril de 2009 a 11 de junho de 2009, através de contatos diretamente estabelecidos com os gerentes de hotéis juizforanos. Esses contatos, entretanto, foram conseqüentes de agendamentos coerentes à disponibilidade daqueles profissionais, determinando a realização de visitas e retornos aos hotéis, cujos gerentes se dispuseram a colaborar para o desenvolvimento desse estudo - com apenas duas exceções, cujos gerentes responderam o questionário (instrumento dessa pesquisa, para coleta de dados) por e-mail.

Em decorrência da aplicação de questionários, obteve-se dados correspondentes à realização das práticas de gestão de pessoas no cotidiano daqueles hotéis. Conciliando as respostas com os objetivos de cada uma das questões que foram formuladas, os dados foram tabulados, de modo a gerar gráficos e tabelas que orientaram a análise e discussão comparativa ao conteúdo levantado pela bibliografia consultada no desenvolvimento da breve revisão de literatura sobre gestão de pessoas em organizações hoteleiras.

Como justificativa para a realização dessa pesquisa, partiu-se do princípio de que o bom desempenho organizacional, enquanto resultado do trabalho efetivo dos empregados, é identificado como critério essencial à garantia de se ter o devido retorno financeiro dos altos investimentos destinados à criação e construção de um empreendimento hoteleiro. As organizações hoteleiras são exclusivamente caracterizadas por se consolidarem como iniciativas privadas, comumente financiadas com capital próprio de somente um proprietário, ou de um pequeno grupo de investidores. Com isso, enfatizou-se a importância em se investigar as práticas de Gestão de Pessoas, uma vez que tal área fornece orientações e diretrizes ao trabalho humano. Um hotel só existirá a partir da realização de serviços que, por sua vez, se consolidarão como resultados de desempenhos de seus funcionários - capital humano de todo e qualquer tipo de organização.

A necessidade de se integrar as equipes de trabalho ao comprometimento com os objetivos e metas de uma organização reflete-se como um tema capaz de instigar o desenvolvimento de pesquisas que, por mais numerosas sejam, dificilmente completarão as lacunas dos conhecimentos organizacionais. Pretendeu-se, com essa pesquisa, promover novas perspectivas ao panorama organizacional-hoteleiro que norteiem, a partir do capital humano, a consolidação de diretrizes e estratégias para o mercado do turismo. 


\section{I - PERSPECTIVAS SOBRE A GESTÃO HOTELEIRA}

Diante do objetivo de se conhecer as práticas de Gestão de Pessoas em hotéis, é válido apresentar uma breve perspectiva sobre o cenário hoteleiro, através de levantamentos de pesquisas e bibliografias, com a intenção de se desenvolver uma breve revisão de literatura acerca das operações estratégicas e operacionais que, além de abordarem princípios e propostas à gestão hoteleira, representam o cotidiano das organizações que prestam serviços de hospedagem.

Assim sendo, o presente capítulo busca resgatar os principais aspectos acerca das perspectivas de gestão hoteleira, notadamente, no que tange às elucidações das potenciais contribuições da gestão de pessoas enquanto área de conhecimento e prática organizacional.

\section{1 - Contextualização e elementos envolvidos nas práticas de gestão em hotelaria}

No campo das atividades que integram o sistema do Turismo, os serviços de hospedagem representam não somente uma condição que possibilite ao turista adquirir conforto e instalação física para a sua manutenção durante sua experiência de viagem e contato com outras culturas, mas também um dos principais pilares de todo aquele sistema, enquanto importante colaborador para o desenvolvimento econômico de uma região. Embora existam inúmeras identidades organizacionais - enquanto representantes de distintos empreendimentos hoteleiros - as práticas de gestão hoteleira apresentam características comuns em diversas localidades, distribuídas por diferentes países em todo o mundo.

Como definição para essa atividade mundial, Hayes e Ninemeier (2005) compreendem que o setor hoteleiro integra a "indústria do turismo", termo esse que diversos outros autores (CASTELLI, 2001; ACERENZA, 2002; PETROCCHI, 2002; RUTHERFORD, 2004) definem como o conjunto de práticas sociais e econômicas que, ao se basear no suporte oferecido a turistas, promovem a geração de lucros e movimento de riquezas, representando, hoje, uma das maiores - e mais rentáveis - práticas em todo o mundo. Neste enfoque, Acerenza (2002) compreende por “indústria turística” o instrumento cujas operações visam atender às necessidades e demandas do turista, garantindo seu deslocamento (fator associado à variável “transporte”), sua permanência no lugar (atividade fim de uma organização hoteleira) 
a exploração e a valorização dos atrativos locais (com ênfases em perspectivas culturais e antropológicas). Conjugada a essa abordagem, Petrocchi (2002) define que três serviços básicos - transporte, hospedagem e atrativos - constituem o produto turístico. Portanto, a hotelaria representa uma das principais bases do Turismo.

Acerca do fator desenvolvimento econômico, as autoras Lobianco e Ramos (2004) salientam que as indústrias petrolífera, bélica, e de turismo são as que mais movimentam recursos no mundo. Enquanto importante atividade econômica no plano internacional, o Turismo apresenta a área de hotelaria como um de seus principais segmentos, destacando-se pela significativa geração de empregos. Assim, pode-se afirmar que a hotelaria representa não somente uma das bases do sistema de Turismo, como, também, um setor importante para a economia mundial.

Com ênfase nas delimitações territoriais para o desenvolvimento econômico de determinadas sociedades, Cruz Júnior e Carvalho (2003) apontam que a área de hotelaria também é reconhecida como importante atividade econômica no Brasil. Frente a essa constatação, observam que para o desenvolvimento desse setor, os modelos de gestão adotados abordam a profissionalização dos administradores de hotéis, bem como a capacitação e treinamento de funcionários. Tais medidas têm por foco a atração de clientes (potenciais hóspedes) e a preocupação com a satisfação desses em coerência à qualidade percebida na prestação dos serviços de hospedagem, oferecidos pelas equipes que atuam nos hotéis.

Tanto Acerenza (2002), como Petrocchi (2002), compreendem a hotelaria como um dos subsistemas do sistema Turismo. Essa visão sistêmica se deve ao fato de que os elementos de um todo (no caso, o sistema turístico) interagem e exercem influências entre si.

Adotando a perspectiva sistêmica, e compreendendo o setor de hotelaria como um subsistema inserido no complexo do Turismo, podem ser identificados vários elementos que compõem esse subsistema. Dentre tais elementos identifica-se o fator da concorrência entre diferentes organizações hoteleiras. Lobianco e Ramos (2004) argumentam que a competitividade entre os hotéis se projeta em todo o mercado mundial, de modo que são fundamentais a criação e implantação de medidas e estratégias para se enfrentar tal concorrência (a exemplo do emprego de ferramentas, de tecnologias da informação e da Internet por parte de alguns hotéis), acompanhando as tendências e novas demandas do mercado consumidor; isto é, dos potenciais hóspedes. 
No campo de pesquisas em Turismo e Hotelaria, podem ser identificadas diversas propostas teóricas para a gestão de um hotel se orientar em relação à concorrência no mercado de prestadoras dos serviços de hospedagem. Uma dessas propostas é levantada pelos pesquisadores Cruz Júnior e Carvalho (2003), ao argumentarem que compreender e monitorar a satisfação do cliente (no caso dos hotéis, os hóspedes) corresponde a uma das principais diretrizes para as empresas - inclusive as de hotelaria - quanto às ações e decisões a serem implementadas em relação à melhoria no atendimento (e prestação de serviços) ao cliente, enquanto fonte de vantagem competitiva.

Nesse enfoque, para se melhor compreender as partes envolvidas na prestação e aquisição dos serviços de hospedagem, os clientes - ou turistas - são classificados como “hóspedes”, uma vez que adquirem serviços de hospedagem. Os autores Hayes e Ninemeier (2005) enfatizam essa classificação específica visto que o atendimento prestado aos hóspedes é diferente do comumente destinado às pessoas que, em um empreendimento qualquer, objetivam apenas adquirir um bem ou serviço. Nessa perspectiva, afirmam que os profissionais que trabalham nos hotéis - classificados como hoteliers - devem ser capacitados a recepcionarem os hóspedes como quem recebe uma visita em sua casa. A maneira como os hóspedes serão tratados corresponderá, portanto, a uma das principais variáveis capaz de promover a identidade de um hotel para o seu mercado consumidor.

De semelhante modo como são apresentadas as vertentes de gestão estratégica em diversos tipos de negócios, Petrocchi (2002) também acredita que fatores do ambiente externo - incluindo o mercado consumidor - podem influenciar e provocar mudanças organizacionais nos hotéis. "Analisar continuamente o meio, perceber ameaças, detectar oportunidades e adotar alternativas de sobrevivência são os desafios da gestão hoteleira estratégica” (p.20), ou seja, para a eficácia da gestão de um hotel, a melhor maneira de se conhecer as possíveis influências macroambientais pode ser identificada ao se investigar a satisfação - e percepção de qualidade - por parte dos hóspedes atendidos, e isso pode ser decisivo para a sobrevivência do hotel frente às suas concorrências mercadológicas no cenário global.

Além do tratamento diferenciado oferecido aos hóspedes, Hayes e Ninemeier (2005) argumentam que os hoteliers devem ser capazes de identificar diferentes tipos de hóspedes atendidos: há quem usufrua os serviços de um hotel apenas para fins de negócios, e há aqueles que se hospedam com fins de lazer. Para cada tipo de hóspede existem demandas específicas (como acesso à Internet de banda larga para hóspedes com fins de negócio, por exemplo; e a busca por saunas e piscinas por parte dos hóspedes com fins de lazer). 
Faz-se necessário destacar que, assim como o cenário do Turismo - enquanto atividade econômica capaz de gerar movimento de recursos (financeiros e humanos) - sofreu significativas mudanças nas últimas décadas, o mesmo ocorreu com práticas hoteleiras. Essa realidade foi observada por Andrade e Brito (2000), ao afirmarem que, para se ajustar ao mercado globalizado e atender às novas e diversificadas demandas do consumidor, a administração hoteleira também criou novos métodos e concebeu novos enfoques ao ampliar a oferta de seus serviços, bem como passou a identificar perfis específicos dos potenciais clientes de hotéis - a exemplo da resultante distinção entre hóspedes de negócio, e hóspedes de lazer.

Entretanto, outros fatores podem ser determinantes sobre o tipo de hóspede de um hotel - além dos estímulos de lazer, ou negócios. Petrocchi (2002) afirma que a renda salarial, a faixa etária e o local de origem são variáveis que também identificam e caracterizam o público atendido numa organização hoteleira. A determinação desses aspectos pode ser condição básica para se definir o que um planejamento estratégico em hotelaria deve contemplar para garantir a eficácia do empreendimento no mercado turístico.

Com base nas referências supracitadas, é possível destacar “elementos” envolvidos nas práticas da gestão hoteleira.

QUADRO 01: Elementos envolvidos em Gestão Hoteleira

\begin{tabular}{|c|c|c|}
\hline ELEMENTO: & $\begin{array}{l}\text { REFERÊNCIA } \\
\text { TEÓRICA: }\end{array}$ & PRÁTICA/ABORDAGEM: \\
\hline Concorrência & \multirow[b]{2}{*}{$\begin{array}{l}\text { Lobianco e Ramos } \\
\qquad(2004)\end{array}$} & $\begin{array}{l}\text { Os hotéis competem, entre si, pela } \\
\text { atração de clientes no mercado } \\
\text { mundial. }\end{array}$ \\
\hline Estratégias em hotelaria & & $\begin{array}{l}\text { Adoção de ferramentas e } \\
\text { tecnologias de informação } \\
\text { (incluindo recursos da Internet) para } \\
\text { atração de clientes e conhecimento } \\
\text { do mercado consumidor. }\end{array}$ \\
\hline $\begin{array}{l}\text { Monitoramento da satisfação } \\
\text { dos hóspedes }\end{array}$ & $\begin{array}{l}\text { Cruz Jr e Carvalho } \\
\text { (2003) }\end{array}$ & $\begin{array}{l}\text { Diretrizes para a tomada de decisões } \\
\text { e implantação de melhorias no } \\
\text { atendimento a clientes. }\end{array}$ \\
\hline Hóspedes & \multirow{2}{*}{$\begin{array}{l}\text { Hayes e Ninemeier } \\
\text { (2005) }\end{array}$} & $\begin{array}{l}\text { Público específico que objetiva } \\
\text { adquirir serviços de hospedagem, } \\
\text { seja para fins de negócio, ou prazer. }\end{array}$ \\
\hline Hoteliers & & $\begin{array}{l}\text { Profissionais que trabalham nos } \\
\text { hotéis, atendendo às demandas dos } \\
\text { hóspedes. }\end{array}$ \\
\hline $\begin{array}{l}\text { Renda salarial, faixa etária e } \\
\text { local de origem dos hóspedes }\end{array}$ & Petrocchi (2002) & $\begin{array}{l}\text { Variáveis que caracterizam os } \\
\text { hóspedes atendidos. }\end{array}$ \\
\hline
\end{tabular}

FONTE: Dados da pesquisa 


\section{2 - Planejamento estratégico em Gestão Hoteleira}

Não serão somente as relações internas, entre as partes que constituem a prestação e aquisição dos serviços de hospedagem, que irão caracterizar as dimensões e focos da administração de um hotel. A gestão hoteleira está diretamente relacionada com a observação e consideração aos fatores externos aos hotéis, a exemplo de questões referentes ao desenvolvimento e sustentabilidade das regiões onde são sediados.

Com isso, dentre as funções administrativas na gestão de um hotel, destaca-se o planejamento estratégico, visto que sua abrangência em fornecer propostas de ações futuras ao seu devido funcionamento organizacional, e a análise das relações estabelecidas com a comunidade que ocupa, segundo Petrocchi (2002), conduzem à concepção da organização hoteleira como um sistema aberto, capaz de influenciar - e ser influenciado por - variáveis de seu ambiente externo (macroambiente). Como elementos desse ambiente, o autor identifica questões relativas ao mercado, os atrativos turísticos, e as atividades mais comuns da região.

O processo de planejamento estratégico é composto pela interação da análise do meio externo com os estudos internos do empreendimento. A visão interna, microeconômica, conjugada com a análise macroambiental são o suporte da concepção e do planejamento de um hotel (PETROCCHI, 2002, p.33).

Considerando os aspectos pertinentes ao planejamento estratégico, é possível afirmar que o sucesso da organização hoteleira se revela como ideal a ser alcançado no futuro através de mudanças quanto às condições que o hotel apresente no momento presente. Para tanto, a implementação de mudanças organizacionais (e, principalmente, a adaptação às mesmas), conforme argumentam Kaplan e Norton (2000) e Lobato et al (2008) só pode ser efetivamente processada por meio de sinergias e comprometimento de uma visão adotada em comum entre os funcionários; isto é, precisa haver compatibilidade entre as ações e intenções dos diferentes setores que integram a estrutura da organização (a exemplo de um hotel). Essa idéia enfatiza a necessidade de um planejamento claro e conciso, ainda sob enfoques prescritivos e, portanto, em fases anteriores ao processo de mudanças organizacionais e às melhorias operacionais e administrativas - de acordo com as proposições de Mintzberg, Ahlstrand e Lampel (2000), e Certo e Peter (2005). 
Vale ressaltar que a efetiva aplicação dos princípios de um planejamento estratégico em um hotel só será possível se houver a compreensão e a determinação de atitudes positivas por parte dos hoteliers. Portanto, a função administrativa de planejar estará diretamente envolvida com as variáveis referentes a comportamentos organizacionais. Tal associação pode representar uma das principais atribuições à gestão de pessoas em um hotel.

\section{3 - Classificações dos serviços e organizações hoteleiras}

De acordo com os estudos de Hayes e Ninemeier (2005) os serviços de hospedagem surgiram em períodos ainda anteriores ao início do século $\mathrm{XX}$, quando famílias de latifundiários recebiam hóspedes em suas casas, sendo que estas, em sua maioria, sempre possuíam diversos quartos - os quais eram oferecidos àqueles hóspedes.

No panorama da prestação de serviços de hospedagem na sociedade contemporânea, os pesquisadores Gava e Silveira (2007) apontam que tais serviços são formadores do produto turístico - enfatizando a concepção da hotelaria como uma das principais bases do sistema Turismo. Esses pesquisadores argumentam que a satisfação dos hóspedes pode ter impacto não somente sobre os serviços adquiridos - considerando apenas a qualidade percebida na prestação desses - mas, também, sobre todo o produto turístico, envolvendo a percepção geral do local visitado.

Assim, é possível correlacionar a gestão hoteleira como fator colaborador ao prazer ou frustração - experimentado por um turista e, conseqüentemente, sobre todo o marketing do turismo de um determinado local.

Uma vez concebida como uma prática comum a qualquer parte do planeta, hoje as classificações dos serviços de hospedagem são padronizadas para diferentes localidades. Frente a essas padronizações, os autores Acerenza (2002), Hayes e Ninemeier (2005) apontam que os estabelecimentos e serviços de hotelaria são classificados de acordo com o nível de qualidade identificado, principalmente, sobre as seguintes variáveis: atendimento aos hóspedes, localização do hotel, valor das diárias, número de apartamentos oferecidos, tipo de público atendido e tipo de profissional responsável pela administração da organização hoteleira (empresas familiares - até mesmo a exemplo de hotéis - tradicionalmente são 
gerenciadas pelos proprietários; mas também há aquelas cujas equipes administrativas são compostas por especialistas, e até mesmo por equipes multidisciplinares).

Em consideração aos indicadores inseridos em pesquisas e práticas de gestão hoteleira, Gava e Silveira (2007) apontam que os índices de "taxa de ocupação” e “tarifa média das diárias” correspondem a referenciais para se medir desempenhos organizacionais dos hotéis, fornecendo subsídios à classificação dos serviços de hospedagem em um hotel.

Acerca dessas classificações, Castelli (2001), por sua vez, enfatiza que essas se estabelecem tendo por referência: o tamanho do hotel (de pequeno, médio, ou grande porte em relação às suas dimensões físicas), o número de leitos e/ou a receita anual da organização hoteleira.

Além dos princípios de classificação, Hayes e Ninemeier (2005) delimitam os segmentos de hotelaria em duas principais grandes áreas: operações hoteleiras (que abordam os serviços para alojamento dos turistas e a administração de centros de convenções, onde se realizam eventos e reuniões de negócios), e operações de alimentos e bebidas (incluindo serviços de restaurante, café da manhã, bares e coffe-breaks). Segundo Petrocchi (2002), as empresas de hotelaria não oferecem apenas serviços de hospedagem. Dependendo do porte da organização (pequeno, médio, ou grande), e do tipo de hóspede atendido, o hotel também pode oferecer espaços destinados a sediar eventos empresariais e cerimônias sociais. Para esses tipos de serviço, o ideal da qualidade no atendimento e foco na satisfação do hóspede se mantém (ou deve se manter) como "filosofia de trabalho" dos hoteliers.

Também é possível observar que as ofertas dos serviços de hospedagem se expandem pelos diferentes tipos de hotéis, conforme Castelli (2001) delimita: desde resorts luxuosos, compostos por redes de diversas organizações distintas, a hotéis com pensão completa (que incluem outros serviços oferecidos, além da simples hospedagem), hotéis com serviços econômicos (quando oferecem, apenas, hospedagem e café da manhã, podendo esse último ser opcional) a pousadas.

Há, ainda, a consideração de que no setor hoteleiro é comum existirem redes de franquias. Isso pode implicar em padronizações no atendimento aos hóspedes, de modo a descaracterizar o acesso desses aos elementos da cultura local, onde o hotel é sediado. Porém, a implantação de franquias pode promover vantagens de marketing e publicidade à atração de hóspedes oriundos de diferentes localidades, já familiarizados com a marca projetada, de modo geral, no mercado. 
Em todo caso, a gestão hoteleira deve visar a atração de clientes e a retenção de hóspedes. Para tanto, Petrocchi (2002) argumenta que a arquitetura e os aspectos físicos da infra-estrutura do hotel podem ser decisivos para a atração de novos clientes. Portanto, o projeto arquitetônico de um hotel deve promover visual atraente e acolhedor, além de empregar elementos da cultura local, de modo a estabelecer sua harmonia com a região onde é sediado. Para o autor, o estilo e a projeção estrutural e física do hotel podem, também, representar vantagens competitivas no seu mercado.

Todavia, o referido autor defende que o foco do negócio hoteleiro deve se concentrar na satisfação das necessidades dos hóspedes (e não somente na oferta e venda de serviços), assim como não pode deixar de priorizar sua oferta de serviços de hospedagem ao envolver outras atividades (como restaurantes e sedes para eventos, por exemplo).

É possível, portanto, correlacionar o bom desempenho de um empreendimento hoteleiro à eficácia da área de gestão de pessoas em um hotel, visto que um dos principais fatores associados ao sucesso desse tipo de negócio concentra-se na qualidade do serviço prestado, conforme percebida pelo público atendido. Incorporar esse ideal como meta aos funcionários da organização prestadora de serviços de hospedagem, de modo a motivá-los, capacitá-los e comprometê-los para o alcance dessa meta representa um significativo desafio para a gestão de pessoas.

QUADRO 02: Classificações dos serviços de hospedagem, de acordo com autores pesquisados

\begin{tabular}{|c|l|}
\hline REFERÊNCIA: & CONCEPÇÕES: \\
\hline \multirow{2}{*}{ Castelli (2001) } & $\begin{array}{l}\text { Tamanho (pequeno, médio, grande porte), número de leitos e } \\
\text { receita anual são variáveis determinantes à classificação de um } \\
\text { hotel. }\end{array}$ \\
\hline Petrocchi (2002) & $\begin{array}{l}\text { Classificação com base no tamanho/porte da organização e dos } \\
\text { serviços que oferece. }\end{array}$ \\
\hline \multirow{2}{*}{$\begin{array}{c}\text { Acerenza(2002); hotel é classificado com base no nível de qualidade dos } \\
\text { serviços de hospedagem, de acordo com a percepção do hóspede } \\
\text { atendido. }\end{array}$} \\
\cline { 2 - 2 } $\begin{array}{c}\text { (2005) } \\
\text { Localização, valor das diárias, número de quartos e qualificação } \\
\text { profissional dos hoteliers também são considerados para a } \\
\text { classificação de um hotel. }\end{array}$ \\
\hline
\end{tabular}

FONTE: Dados da pesquisa 


\section{II - O CARGO DE GERENTE GERAL EM HOTELARIA}

O presente capítulo objetiva descrever o papel do gerente geral em hotelaria, uma vez representando o profissional cujas atribuições se concentram na adequação das expectativas dos proprietários e investidores de hotéis, sob a forma de planejamentos às atividades que deverão ser realizadas por todos os demais profissionais que integram o contexto interno de um hotel. Assim sendo, será aquele gerente que assumirá posição e função mediadora da motivação dos hoteliers, de melhorias contínuas e inovações no trabalho desenvolvido na organização hoteleira e no monitoramento da qualidade percebida pelos hóspedes atendidos. Nessa perspectiva, estima-se que tal nível de gerência exija o conhecimento sobre como se processam as práticas de todos os setores que compõem uma organização hoteleira incluindo a área de Gestão de Pessoas, foco dessa pesquisa.

Uma vez representando organizações que prestam serviços, os hotéis também devem ser analisados como um setor que compõe a diversidade organizacional no mundo. Dentre as mudanças culturais e socioeconômicas que afetam o cenário global e o mercado de trabalho, a autora Pimenta (2006) ressalta que o modelo de produção fordista - fortemente caracterizado pela produção em série, cultura e consumo de massas - determinou padrões de desenvolvimento social e econômico no período pós-Segunda Guerra Mundial. Tal modelo, observa, culminou na criação e desenvolvimento do "setor de serviços” como movimento de emprego. É nesse setor que se inserem os profissionais de turismo, incluindo os de hotelaria.

Como toda organização, um hotel também apresenta, em sua estrutura, um quadro de funcionários, responsáveis pela realização de todas as tarefas e processos que representam o funcionamento e propósitos da empresa. No contexto de um empreendimento hoteleiro, o quadro de funcionários se ilustra pelo conjunto de diversos setores e profissionais distintos que precisam trabalhar em sinergia para o movimento, funcionamento e produção de todo o complexo organizacional. Dentre aqueles funcionários, é possível destacar o papel do “gerente geral do hotel” como uma das figuras mais representativas e responsáveis pelo sucesso de toda a organização a longo prazo, visto que sua principal atribuição consiste em adequar os desempenhos de todas as equipes de trabalho às expectativas e metas dos proprietários e investidores, bem como apresentar a esses as reais condições, necessidades e realizações daquelas equipes que conduzem o desenvolvimento de seus empreendimentos. Para tanto, os gerentes gerais devem estar aptos a apresentar análises englobando fatores 
macroorganizacionais, em especial àqueles capazes de representar influências sobre o público alvo e sobre a concorrência de mercado.

Diversos pesquisadores sobre a temática “gestão hoteleira” (CASTELLI, 2001; PETROCCHI, 2002; RUTHERFORD, 2004; HAYES E NINEMEIER, 2005) enfatizam a necessidade de análises macro e microorganizacionais para a formulação e aplicação de planejamentos estratégicos ao desenvolvimento das organizações hoteleiras. Atribui-se essas realizações ao cargo do gerente geral de hotel; além disso, é possível destacar fenômenos globais naquele tipo de análise macroorganizacional.

Acerca das conseqüências da globalização, Pimenta (2006) observa que a economia da sociedade contemporânea - incluindo o foco sobre os setores de serviços, nos quais se insere a hotelaria - se caracteriza pela supremacia das grandes empresas e corporações (a exemplo das multinacionais) sobre as pequenas; pela busca do conhecimento e aprimoramento profissional; e pela necessidade de se aplicar métodos flexíveis, coerentes às avaliações e monitoramentos para se melhor atender às reais necessidades do público consumidor. Com isso, a autora destaca que a gestão da produção e prestação de serviços sofre alterações ao longo do tempo, a exemplo da adoção de inovações tecnológicas como meio de se superar a concorrência de mercado.

Segundo Hayes e Ninemeier (2005) a função “gerente geral” de um hotel é representada pelo profissional cuja responsabilidade se concentra na tomada de decisões, além de intermediar as relações entre os proprietários e as equipes internas de um hotel, bem como intermediar as relações com a franquia (quando se tratar desse tipo de empreendimento, comumente caracterizado por redes multinacionais) e, ainda, representar a organização em que atua na localidade onde a mesma é sediada. Os autores também definem que o gerente geral é encarregado pela definição de diretrizes e pela supervisão de tarefas determinadas ao devido funcionamento gerencial e operacional de todo o hotel. Assim sendo, o papel do gerente geral é bastante significativo, visto que suas ações são determinantes para o sucesso da organização.

Dentre aqueles que descrevem as características da função, Davies (2001) argumenta que a figura do gerente geral é a principal responsável pelo sucesso e bom desempenho organizacional do hotel, uma vez que assume posição centralizadora à adequação dos procedimentos administrativos e operacionais às políticas e metas empresariais. É o gerente 
geral quem estabelece comunicação direta com os investidores, proprietários, empreendedores e, em paralelo, com todos os funcionários do hotel - os hoteliers.

Uma vez atribuídas importâncias tão significativas àquele gerente de hotel, é comum associá-lo à figura de líder de toda a equipe, e da gestão da organização hoteleira.

Assim como os fatores “estrutura”, “localização”, “tipo de hotel” e "nível de qualidade no atendimento aos hóspedes” determinam a classificação de um hotel, esses mesmos fatores - segundo Hayes e Ninemeier (2005) - também revelam as responsabilidades de um gerente geral; bem como o orientam sobre quais valores deverá priorizar na execução de suas tarefas e atribuições.

Uma vez encarregado por apresentar os procedimentos cotidianos (incluindo a exposição de necessidades de novos investimentos para a continuidade do negócio) para seus investidores - ou proprietários -, o gerente geral do hotel também assume a tarefa de representar uma imagem positiva da organização para o seu mercado, com o propósito de atrair maior rentabilidade ao empreendimento. Assim:

\footnotetext{
(...) a habilidade para informar de maneira eficiente investidores e proprietários de um hotel sobre seu desempenho e possíveis necessidades é fundamental para o sucesso da organização a longo prazo (HAYES e NINEMEIER, 2005, p.30).
}

É preciso ressaltar que quando se tratar de um hotel franqueado, o gerente geral também se responsabiliza por administrar a marca dessa franquia.

Hayes e Ninemeier (2005) também acreditam que a melhor maneira de se conhecer as práticas e realidades hoteleiras é estabelecendo contatos com os gerentes gerais de hotéis. Nessa perspectiva, a presente pesquisa se baseia na aplicação de questionários, de modo a coletar opiniões e informações de gerentes gerais que atuam no setor hoteleiro de Juiz de Fora, focando, principalmente, questões relativas às práticas de gestão de pessoas em hotéis. 


\section{1 - Principais responsabilidades do cargo}

Para se definir o cargo de gerente geral de um hotel, Petrocchi (2002) argumenta que enquanto a maioria dos funcionários de uma organização hoteleira deve apresentar habilidades técnicas e humanas (relativas, respectivamente, ao conjunto de conhecimentos específicos para processos operacionais, e às ações orientadas para a eficácia da comunicação e coordenação de pessoas) o gerente geral, além desses tipos de habilidades, também deve manifestar domínios de habilidades conceituais. Essas, por sua vez, representam competências para se desenvolver diagnósticos organizacionais, bem como para se propor intervenções baseadas em informações pertinentes à gestão hoteleira, possibilitando, assim, a definição de diretrizes à administração do negócio hoteleiro. Neste enfoque, o autor afirma que "quanto mais elevados são os cargos no hotel, mais o administrador necessita das habilidades conceituais” (PETROCCHI, 2002, p.15).

As habilidades conceituais, por sua vez, revelam práticas nas ações empreendidas, principalmente, no planejamento estratégico de um hotel. Portanto, são habilidades imprescindíveis para a existência - e sobrevivência - da organização hoteleira em seu mercado, cada vez mais competitivo.

A plenitude da atribuição de planejamento estratégico ao cargo de gerente geral, num hotel, se explicita quando Gava e Silveira (2007) argumentam que as ações empreendidas no contexto de uma indústria hoteleira devem ser orientadas pelas perspectivas de seus clientes os hóspedes - e não somente pelas concepções dos proprietários e investidores do hotel. Mediar esses dois focos extremos da gestão hoteleira é uma das principais atribuições do gerente geral de um hotel.

Semelhante abordagem pode ser observada em Hayes e Ninemeier (2005), ao apontarem como responsabilidades do gerente geral as atividades de planejamento. Essas se baseiam na definição e determinação de diretrizes e ações que regerão todo o funcionamento do hotel. Para tanto, o gerente geral deve orientar os demais gerentes para definir o que será esperado como resultados das realizações de cada um dos setores (ou departamentos), além de gerir recursos que possibilitem empreender ações planejadas e alcançar as metas determinadas. 


\section{2 - Atribuições de liderança ao Gerente Geral de um hotel}

As atribuições de um gerente geral de hotel são inúmeras, variando bastante em função do foco e do tipo de hotel, todavia a literatura e pesquisas sobre o assunto sinalizam que desenvolver o consentimento de que propor serviços de hospedagem com maior percepção de qualidade por parte dos hóspedes, formar atitudes positivas à realização de tarefas cotidianas do hotel, desenvolver competências e aprimoramento profissional, além de conferir a efetividade dos treinamentos destinados às equipes de trabalho da organização e comunicar as expectativas dos proprietários de investidores - sob a forma de metas empresarias - sugerindo estratégias e planos de ação aos hoteliers, são exemplos de tarefas que caberiam ao Departamento de Recursos Humanos, conforme apontam Davies (2001) e Castelli (2001). Entretanto, tais responsabilidades são comumente atribuídas ao gerente geral de hotel, uma vez que esse profissional assume posição de líder na organização hoteleira.

O perfil de liderança necessário ao gerente geral de um hotel, segundo Hayes e Ninemeier (2005), se expressa quando esse assume a responsabilidade de orientar os demais gerentes, e seus respectivos setores que compõem a estrutura da organização onde trabalham. Independente do porte do hotel - se é grande, com um número maior de departamentos; ou se é pequeno, com um número menor de departamentos - caberá ao gerente geral orientar as práticas gerenciais. Para tanto, esse gerente deve conhecer os fundamentos profissionais de cada área envolvida na estrutura hoteleira. Com base nessas concepções, justifica-se o interesse e relevância em investigar as percepções e opiniões dos gerentes gerais de hotéis sobre as práticas de Gestão de Pessoas nas organizações onde atuam profissionalmente.

\section{3 - Sobre a qualidade dos serviços de hospedagem}

De acordo com o princípio de que uma empresa existe com o propósito de atender às demandas de um mercado, faz-se necessário considerar o público consumidor dos serviços de hospedagem oferecidos por um hotel, como uma das variáveis determinantes à efetividade nas ações do gerente geral.

Nesse enfoque, Ross (2002) argumenta que o turista se representa na imagem do ser humano desejoso de se distanciar, em determinado intervalo de tempo, de sua rotina profissional, do seu cotidiano e do contexto de seu trabalho, muitas vezes associando a 
oportunidade de viajar com sua família como uma experiência capaz de promover prazer. Diante dessa concepção, pode ser decisivo à qualidade do atendimento aos hóspedes - e na prestação dos serviços de hospedagem - conhecer o perfil do turista que venha a se hospedar em hotéis. Tal conhecimento também pode se atribuir às responsabilidades do gerente geral do hotel, visto que sua principal contribuição ao sucesso do empreendimento hoteleiro consiste em adequar os esforços das equipes de trabalho ao bom desempenho organizacional e à realização das metas empresariais do hotel.

Adotando aquelas metas à concepção de atender às expectativas dos investidores e proprietários, o gerente geral do hotel - na visão de Davies (2001) - deve orientar e definir diretrizes às equipes de trabalho, internas ao hotel, de modo a conduzir seus melhores desempenhos, resultando em lucratividade e rentabilidade da organização hoteleira - e isso só é possível com a determinação da qualidade na prestação dos serviços de hospedagem.

Compreendendo os hotéis como organizações prestadoras de serviços, essas, de maneira geral, adotam por objetivo superar suas concorrentes e garantir maior atração de clientes. Assim, Pimenta (2006) argumenta que o fator qualidade é determinante à melhoria dos processos produtivos e à prestação de serviços. No cenário hoteleiro, caberá ao gerente geral definir os indicadores de qualidade de suas equipes de trabalho, e orientar os esforços para que tal fator se materialize na prestação dos serviços de hospedagem, bem como no atendimento destinado aos hóspedes, e realizado por cada profissional que assume a "linha de frente” do hotel.

Para a efetiva gestão da qualidade nos serviços de hospedagem, Davies (2001) define que identificar, avaliar e monitorar os indicadores da percepção dos hóspedes atendidos são responsabilidades atribuídas ao gerente geral do hotel. Além disso, também afirma que cabe a esse gerente explicar aos funcionários, e às equipes de trabalho do hotel - os hoteliers - quais são os objetivos da avaliação da qualidade nos serviços prestados aos hóspedes. Para tanto, talvez o gerente geral precise conferir se os treinamentos oferecidos àqueles hoteliers fornecem e garantem competências focadas nos princípios da qualidade - em coerência às necessidades e expectativas dos potenciais hóspedes - nos serviços que prestarão.

Para a definição do termo “qualidade”, Pimenta (2006) aponta que existem diferentes propostas, mas em todas elas o elemento comum se concentra no melhor atendimento às exigências do cliente. Entretanto, alcançar a qualidade só é possível por meio da orientação às ações humanas num contexto organizacional. “A qualidade depende da integração entre as 
pessoas e para obtê-la é preciso investir na criação de um ambiente com cultura e clima organizacional favoráveis” (PIMENTA, 2006, p.106).

Em um hotel, caberá ao gerente geral orientar o desempenho das equipes ao cumprimento das metas empresariais, bem como à determinação da qualidade nos serviços ali prestados. Todavia, essa qualidade pode ser promovida através de melhorias que, por sua vez, podem resultar de críticas e opiniões advindas dos próprios funcionários que prestam os serviços.

Adotar o método de se identificar as reais necessidades dos clientes destaca-se, segundo Cruz Júnior e Carvalho (2003), como um aspecto decisivo à obtenção e determinação de vantagem competitiva sobre a concorrência, entre empresas prestadoras de serviços, incluindo a competitividade entre hotéis.

Frente a essa associação com diferenciais competitivos no mercado, Pimenta (2006) define que a qualidade na prestação de serviços se determina pela identificação dos desejos dos clientes atendidos, bem como pela padronização ao realizar atendimentos aos clientes, visto que padronizar consiste em definir a finalidade daquele serviço, seus efeitos, e como mensurá-los. Como exemplo de um possível efeito, plausível de mensuração, quanto à padronização da realização de serviços, a autora apresenta “o tempo de demora” com que um potencial hóspede espera para receber informações sobre um hotel, ao telefonar para um de seus atendentes, ainda antes de viajar; ou seja, gastando uma ligação interurbana e já podendo conhecer, mesmo previamente, a eficiência dos hoteliers daquele hotel.

Contudo, não se pode deixar de ressaltar que a qualidade, na prestação e aquisição dos serviços de hospedagem, é diretamente relacionada à percepção do hóspede sobre a maneira com que é tratado pelos hoteliers que o atendem. Somente um adequado programa de Gestão de Pessoas poderá desenvolver atitudes em funcionários de um hotel. Entretanto, é importante ao gerente geral observar, atentamente, as posturas e comportamentos dos funcionários, principalmente aqueles que assumem a "linha de frente”, isto é, que estabelecem contato direto com os hóspedes.

Vale ressaltar estudos de pesquisadores na área de comportamento organizacional e aspectos pertinentes às relações interpessoais num contexto organizacional, como os de Zanelli e Silva (2008) ao argumentarem que as organizações são construídas pelas interações entre seus respectivos funcionários. Esse pensamento também se associa aos paradigmas decisivos à implantação do foco sobre a qualidade dos produtos e serviços processados por 
uma empresa. Contudo, as interações humanas de uma organização não se restringem apenas aos funcionários, mas também se estendem aos contatos estabelecidos com o público consumidor atendido.

No contexto de um hotel, e sob a perspectiva de se identificar a qualidade na prestação dos serviços de hospedagem, Pimenta (2006) afirma que a aplicação de questionários - os quais os hóspedes possam responder voluntariamente - corresponde a uma efetiva alternativa. Além disso, é importante avaliar, de acordo com a perspectiva do hóspede, variáveis como: acolhimento, rapidez no atendimento, higiene, cortesia dos hoteliers, classificações referentes à infra-estrutura do hotel, se o recomendaria, etc. Contudo, os resultados das avaliações de atendimento devem promover melhorias, e não se basear, apenas, num procedimento documental.

\section{4 - A motivação das equipes de trabalho como diferencial estratégico aos serviços de hospedagem}

Além dos indicadores de qualidade, a eficiência das atividades de gestão, por parte do gerente geral de hotel, pode ser obtida através dos princípios de melhoria contínua à realização de tarefas cotidianas no contexto da organização hoteleira. Para tanto, Davies (2001) argumenta que pode ser necessário ajustar as estratégias de cada setor - ou equipe de trabalho - do hotel. Além disso, para garantir a promoção de melhorias nos procedimentos administrativos e operacionais, o gerente geral deve ser capaz de conquistar a confiança dos demais funcionários do hotel, possibilitando-os expressar suas críticas, sugestões e opiniões sobre as atividades que realizam.

Uma vez responsável por orientar o trabalho de todos os funcionários e demais gerentes do hotel, o gerente geral deve apresentar habilidades para ensinar e encorajar. Tais habilidades, portanto, representam requisitos para uma liderança, de modo que suas realizações possibilitem alcançar resultados positivos e atitudes de colaboração por parte dos membros das equipes de trabalho.

Além de motivar os funcionários, o gerente geral do hotel também deve ser capaz de avaliar a eficiência de todas as ações executadas - tanto por ele mesmo, como pelas equipes de modo a confirmar se as metas e objetivos organizacionais estão, de fato, sendo alcançados. Nessa concepção, Petrocchi (2002) argumenta que o gerente geral de um hotel deve 
apresentar habilidades humanas, isto é, revelar potencial para compreender as atitudes dos funcionários, motivá-los e corresponder às expectativas que esses possuam em relação ao papel de líder eficaz.

Adotando o foco sobre a motivação humana para o trabalho, Ross (2002) aponta que existem várias teorias sobre essa temática, algumas dessas são brevemente apresentadas no quadro 03. Todavia, identificar os tipos de recompensas mais impactantes ao melhor desempenho de uma equipe de trabalho, no contexto de um hotel, representa uma alternativa para se orientar planos e ações não somente do setor de RH, mas também ao gerente geral daquele hotel. Portanto, é possível afirmar que cabe àquele gerente determinar quais possam, de fato, ser as teorias e técnicas motivacionais mais ideais em relação às características e propriedades de um específico contexto hoteleiro, considerando a efetiva realização das metas e expectativas dos proprietários e investidores.

QUADRO 03: Teorias sobre a motivação humana para o trabalho

\begin{tabular}{|c|c|c|}
\hline AUTOR DA TEORIA: & TEORIA/FOCO: & ABORDAGENS DA TEORIA: \\
\hline Kurt Lewin (1930) & Interações Humanas & $\begin{array}{l}\text { Objetivos compartilhados } \\
\text { promovem o trabalho em equipe. }\end{array}$ \\
\hline Henry A. Murray (1938) & $\begin{array}{c}\text { Teoria das } \\
\text { necessidades }\end{array}$ & $\begin{array}{l}\text { As necessidades que motivam o } \\
\text { homem para o trabalho mudam, e a } \\
\text { intensidade de uma não determina a } \\
\text { outra. }\end{array}$ \\
\hline Frank Stagner (1950) & $\begin{array}{l}\text { Importância do } \\
\text { trabalho }\end{array}$ & $\begin{array}{l}\text { Estabilidade no emprego é o } \\
\text { principal determinante motivador } \\
\text { para o trabalho. }\end{array}$ \\
\hline $\begin{array}{l}\text { Morse, N.L. e Weiss R.S. } \\
\text { (1955) }\end{array}$ & $\begin{array}{l}\text { Continuidade no } \\
\text { trabalho, } \\
\text { independente de } \\
\text { riqueza acumulada }\end{array}$ & $\begin{array}{l}\text { Mesmo se herdassem uma } \\
\text { quantidade de dinheiro suficiente } \\
\text { para toda a vida, as pessoas não } \\
\text { deixariam de trabalhar. }\end{array}$ \\
\hline Victor Vroom (1964) & $\begin{array}{l}\text { Teoria da Expectância } \\
\text { (ou da Expectativa) }\end{array}$ & $\begin{array}{l}\text { O que pode se esperar como } \\
\text { resultados futuros orienta o trabalho } \\
\text { realizado no momento presente. }\end{array}$ \\
\hline Abraham Maslow (1970) & $\begin{array}{c}\text { Hierarquia das } \\
\text { necessidades humanas }\end{array}$ & $\begin{array}{l}\text { Sete níveis de necessidades } \\
\text { humanas (fisiológicas, de } \\
\text { segurança, sociais, sentimento de } \\
\text { realização, conhecimento e estética) } \\
\text { representam os elementos que } \\
\text { motivam o homem para o trabalho. }\end{array}$ \\
\hline David McClelland (1971) & $\begin{array}{l}\text { Divergências entre as } \\
\text { necessidades }\end{array}$ & $\begin{array}{l}\text { A necessidade humana somente se } \\
\text { define por interesses frente a uma } \\
\text { situação-alvo. }\end{array}$ \\
\hline
\end{tabular}

FONTE: Ross (2002) 


\section{5 - A Gerência Geral em Hotelaria como mediadora à promoção de inovações e de manifestações do potencial criativo de hoteliers}

Embora um hotel seja capaz de alcançar diferencial estratégico no seu cenário de mercado turístico, é importante que se busque inovar, como esforço de se conquistar novas vantagens competitivas, visto que, à medida em que apresenta bons resultados, seus concorrentes provavelmente tenderão a seguir seu exemplo, de modo que suas primeiras vantagens competitivas deixarão de ser “diferenciais”.

Neste enfoque, a introdução de práticas inovadoras é compreendida como exemplo de estratégias empresariais. Gondim et al (2006) delimitam que os gestores de uma empresa (a exemplo de um gerente geral de hotel) podem se deparar com - ou assumir - posições de planejar e orientar ações, especialmente quando é possível controlar as variáveis do ambiente. Assim, concentram esforços para a definição da posição assumida - e o reposicionamento de sua respectiva organização em seu mercado.

Com base nessas concepções, os referidos autores definem que toda inovação é composta por: criação (individual, grupal, ou resultante do contato com outros modelos, passíveis de imitação), operacionalização (apresentar viabilidade prática) e difusão (tornar possível a propagação e disseminação das novas idéias).

Além deste conceito, os autores também argumentam que a inovação pode ser promovida por condições de um bom clima organizacional, caracterizado por ser um ambiente aberto a novas idéias, que estimule a criatividade de seus membros, e voltado à aprendizagem contínua.

Portanto, critérios do clima organizacional podem influenciar na manifestação e desenvolvimento do potencial criativo dos funcionários da organização. No caso de um hotel, o gerente geral deve ser capaz de conhecer e identificar o clima organizacional da empresa (fator esse investigado pela equipe de RH) para orientar o desempenho dos hoteliers, e valorizar seus potenciais criativos do modo mais efetivo possível.

O clima organizacional adequado pode estimular a criatividade individual e coletiva na empresa. Para se criar e manter o clima organizacional adequado, deve-se cuidar da seleção de pessoal, do treinamento do potencial criativo, da iniciativa, da autonomia e da capacidade de trabalhar em equipe. O clima criativo não necessariamente deve ser tranqüilo. A geração de crises (porém, controladas) em alguns casos, pode ser uma prática produtiva (PIMENTA, 2006, p.121) 
Com base nessa argumentação, a autora ressalta que a inovação resulta da adição do conhecimento ao produto - ou serviço. Aquele conhecimento, por sua vez, se origina no envolvimento individual do funcionário com a realização de suas respectivas tarefas (o que se define por “conhecimento tácito”), podendo se expandir para todo o processo produtivo, bem como para toda a organização, ao ser divulgado aos demais colegas das equipes de trabalho (tornando-se “conhecimento explícito”, uma vez podendo ser transmitido a outros).

O trabalho em equipe pode promover soluções mais rápidas e criativas por constituir a diversidade individual. Zanelli e Silva (2008) acreditam que o sucesso de uma organização é conseqüente do desenvolvimento de habilidades individuais, embora o trabalho em equipe só possa alcançar êxito se houver cooperação entre seus integrantes.

Além do ideal da inovação, Gondim et al (2006) afirmam que a qualidade total, numa empresa, é o resultado da efetiva participação e desenvolvimento das pessoas que nela atuam. O envolvimento do trabalhador, portanto, é requisito principal para a qualidade na organização, e práticas de gestão que orientem para esses princípios podem ser implementadas através da realização de treinamentos numa organização. Davies (2001) e Hayes e Ninemeier (2005) destacam que, entre as responsabilidades de um gerente geral de hotel, também se insere o monitoramente e avaliação da efetividade dos treinamentos aplicados aos hoteliers.

Pimenta (2006) acredita que buscar inovações na produção e prestação de serviços pode ser uma alternativa estratégica para empresas - incluindo hotéis - lidarem com a concorrência, e para estabelecerem seus próprios desenvolvimentos e progressos. A autora destaca que muitos administradores concebem a inovação como condição fundamental à sobrevivência de uma empresa. Contudo, o maior desafio para os gestores de negócios, a exemplo de um empreendimento hoteleiro, concentra-se no gerenciamento de equipes de trabalho, considerando o ideal de inovar processos cotidianos, principalmente para se alcançar a confiança dos demais profissionais à possível melhoria e efetividade conseqüentes de uma inovação; até porque inovar implica na adoção de novos métodos em descarte aos padrões já conhecidos.

Estima-se que, para o sucesso de um empreendimento hoteleiro, é fundamental ao gerente geral acompanhar as tendências do mercado no setor de hotéis. Para tanto, o 
desenvolvimento do conhecimento organizacional representa uma fonte significativa para vantagens competitivas sobre a concorrência de mercado. 


\section{III - PRÁTICAS DE GESTÃO DE PESSOAS EM HOTELARIA}

O desempenho do profissional de um local, especificamente num determinado lugar de atratividade turística, terá impacto direto sobre o prazer do turista, motivando o seu retorno. Esse princípio se aplica à realidade de um hotel. Com isso, é possível afirmar que a qualificação e gestão de pessoas são fundamentais para a formação profissional - e diferencial mérito - ao profissional do turismo, inclusive os hoteliers.

Conforme mencionado no capítulo anterior, o gerente geral de hotel também assume responsabilidades pertinentes à área de Gestão de Pessoas. Contudo, faz-se necessário contextualizar tais práticas das organizações hoteleiras, sob o enfoque da prestação de serviços de hospedagem. Além disso, ainda que as práticas da administração dos recursos humanos não sejam diretamente atribuídas àquele gerente geral, essa pesquisa tem por objetivo conhecer as concepções de tal gerência sobre essa área organizacional. Para tanto, o presente capítulo apresenta uma breve contextualização dos conhecimentos em gestão de pessoas associados à hotelaria, tendo, por base, o desenvolvimento de uma revisão de literatura contemplando essas duas temáticas.

\section{1 - Associações entre Gestão de Pessoas e Hotelaria}

A área de Gestão de Pessoas deve fornecer subsídios às organizações para, por meio dos recursos humanos nelas inseridos, serem capazes de se adaptar às constantes mudanças do cenário organizacional e mercadológico. A concepção de que as pessoas devem ser controladas no contexto de trabalho (a exemplo do que fazem os setores de Departamento Pessoal em algumas empresas) já é uma idéia refutada. Hoje se compreende que o desempenho - e satisfação - das pessoas é essencial para o sucesso de toda e qualquer organização. Assim, a Gestão de Pessoas assume importância estratégica ao orientar como os funcionários podem melhor contribuir e gerar valor às organizações em que se inserem (ULRICH, 1998; ZAVAGLIA, 2006; ZANELLI E SILVA, 2008).

Dentre diversos pesquisadores que investigam o panorama organizacional, Wood Jr. (1995) acredita que, para enfrentar os desafios provenientes de uma ambiente mutável e competitivo, as organizações passarão a depender muito mais do nível de motivação de sua 
força de trabalho. Essa, por sua vez, deverá ter uma especialização e um grau de comprometimento com a empresa maior que o atual. Por essa razão, a Administração de Recursos Humanos é uma das áreas que mais vem sofrendo mudanças, de modo a poder adequar-se às novas demandas por inovação, competência, capacidade competitiva e excelências colocadas pelas organizações e seu ambiente - esses mesmos princípios também se aplicam à Gestão Hoteleira, especialmente nos estudos que têm por foco considerar as perspectivas dos hóspedes, enquanto clientes das organizações de hotelaria (HAYES E NINEMEIER, 2005; PIMENTA, 2006). Transformações encontradas no macroambiente das empresas - tais como o crescente desenvolvimento tecnológico, a globalização, novas exigências dos consumidores e outros desafios -, correspondem a fatores desencadeadores de uma nova forma para se avaliar as competências da força de trabalho de uma organização, bem como necessidades de qualificação profissional de hoteliers.

Diante destas concepções, autores como Ulrich (1998), Teixeira et al (2006) e Zavaglia (2006), afirmam que os profissionais da área de RH devem avaliar se os padrões naturalmente adotados na realidade das empresas, e apresentados como "valores, regras e normas” por uma cultura organizacional - de fato representam as melhores alternativas para se alcançar os resultados mais efetivos de uma equipe de trabalho. A acomodação com aqueles padrões pode levar à imposição de moldes burocráticos, à estagnação das realizações operacionais, bem como restringir as habilidades sobre as práticas de gestão de pessoas.

Constatada esta possível influência prejudicial a uma empresa (a exemplo de um hotel), ao se mudar os padrões (e, consequentemente, toda uma cultura organizacional), Ulrich (1998) aponta que novas idéias poderão emergir, formando assim novas estratégias para as organizações e novos métodos às práticas de $\mathrm{RH}$, substituindo um "padrão burocrático" pelo trabalho criativo e voltado a concentrar esforços para se garantir o alcance do cumprimento das metas e realização dos objetivos de uma organização.

Para que os profissionais de RH dominem um novo papel, centrado em
resultados com novos padrões de comportamentos, é necessário a ocorrência
de aprendizado e ao mesmo tempo de desaprendizado. Aprender significa
considerar novas alternativas. Desaprender significa continuar no passado.
Ambos são necessários para que o futuro do setor seja beneficiado com seu
passado (ULRICH, 1998, p.10)

Como exemplo de objetivos organizacionais, e associando esse conceito ao contexto de uma organização hoteleira, têm-se o cumprimento aos ideais e expectativas de um 
proprietário que opta por investir nesse tipo de negócio. Tais expectativas somente serão capazes de serem realizadas através da excelência de serviços prestados por equipes de hoteliers que, por sua vez, deverão ser devidamente orientados por gerentes do hotel com suporte da Gestão de Pessoas, ou dos “diretores de Recursos Humanos” (RUTHERFORD, 2004; CASTELLI, 2001; DAVIES, 2001).

Compreendendo que a estrutura organizacional de um hotel é constituída por diversos departamentos e/ou setores, a área referente à Gestão de Pessoas deve existir como apoio, com a missão de fornecer informações, prover novas contratações e apoiar as tomadas de decisão gerenciais, de modo a comunicá-las às execuções dos funcionários de nível operacional. Assim sendo, Hayes e Ninemeier (2005) concebem aquela área como responsável por atender às necessidades dos funcionários do hotel, bem como à execução das tarefas devidamente planejadas pelos gerentes de hotelaria.

\footnotetext{
A equipe de recursos humanos não admite nem demite funcionários; seu papel é encontrar os profissionais necessários e fornecer aconselhamento técnico sobre leis trabalhistas, treinamentos e atividades relacionadas (HAYES e NINEMEIER, 2005, p.19)
}

Em qualquer contexto organizacional, avaliar a adequação dos esforços humanos às diretrizes definidas por metas e estratégias - especialmente no que tange às concepções de um planejamento em RH - implica em se pensar, mensurar e avaliar a "produtividade" das equipes de trabalho. Acerca do conceito de produtividade numa empresa hoteleira, Castelli (2001) o compreende como a maneira de se produzir mais, gastando a menor proporção possível de recursos. Isso pode ser entendido como a adoção de métodos administrativos mais ideais para se alocar o trabalho das equipes de hoteliers, de modo a atender a maior amplitude possível de demandas dos hóspedes (incluindo a busca por conforto, segurança e bom atendimento), satisfazendo as preferências desses.

Em todo caso, agradar os hóspedes representa uma condição comumente defendida, por diversos autores (PETROCCHI, 2002; DAVIES, 2001; PIMENTA, 2006), para se alcançar o sucesso em um empreendimento hoteleiro. Todavia, tal condição só é possível através do contato daqueles clientes com os profissionais do hotel. Com isso, enfatiza-se a relevância em estudar a gestão de pessoas direcionada aos hoteliers. 
Nesse sentido, Zavaglia (2006) argumenta que para uma organização se adaptar às mudanças impostas pelo seu ambiente externo (tendo como exemplo potenciais preferências dos clientes, do público atendido), não basta apenas estabelecer planos - é fundamental correlacionar o potencial humano à geração de valor estratégico. Para o ajuste da gestão de pessoas ao planejamento estratégico da organização, é necessário, portanto, se analisar as propostas do que é planejado de acordo com as competências humanas ali inseridas. Isso implica em conhecer o contexto interno da organização, visto que uma estratégia somente será efetivamente implantada através das funções que cada funcionário executa.

Nesse enfoque, os autores Petrocchi (2002), Hayes e Ninemeier (2005) acreditam que o sucesso da eficácia - e diferencial estratégico de um hotel, em seu mercado competitivo está concentrado na qualidade do atendimento oferecido aos hóspedes. Destaca-se, nessa concepção, a preocupação com a formação e capacitação dos hoteliers - fatores estes associados aos ideais e missões da área de Gestão de Pessoas.

Os hotéis bem-sucedidos utilizam estratégias eficazes para prestar, regularmente, serviços de boa qualidade aos hóspedes. Os avanços tecnológicos podem contribuir para esse processo (...). Além disso, o desenvolvimento dos funcionários vem se tornando um aspecto de importância cada vez maior: os gerentes gerais procuram treiná-los eficazmente para prestar serviços de boa qualidade e, com isso, levar os hotéis a alcançar alto grau de excelência (HAYES E NINEMEIER, 2005, p.20).

O autor Castelli (2001) identifica a qualidade dos serviços de hospedagem como critério de promoção de vantagens competitivas sobre a concorrência de mercado. Compreendendo tal correlação como orientação à formulação de estratégias às organizações hoteleiras, a qualidade identificada (e percebida) no atendimento aos hóspedes assume especial importância, capaz de fornecer diferenciais estratégicos para um determinado hotel no mercado turístico.

Assim sendo, Zavaglia (2006) enfatiza que cabe à gestão de pessoas orientar os processos internos, possibilitando o alcance das metas competitivas da empresa, através da adoção de uma estratégia implantada. Para tanto, é essencial que haja sinergia entre diferentes equipes de trabalho, bem como tornar os objetivos organizacionais compatíveis aos interesses dos empregados, de modo que acreditem na possibilidade de crescimento pessoal 
emparelhada ao desenvolvimento da organização, enquanto resultado do comprometimento com o trabalho.

\footnotetext{
É cada vez mais crucial que as organizações, por meio do seu planejamento de recursos humanos, seja capaz de saber antecipadamente se as pessoas que compõem o seu quadro possuem ou não competências necessárias a fim de contribuir para o alcance da vantagem competitiva que precisa ser desenvolvida (ZAVAGLIA, 2006, p.61)
}

Davies (2001) concebe como uma das principais metas à gestão de pessoas em hotelaria maximizar a produtividade dos hoteliers, de modo a atingir os objetivos dos serviços de hospedagem.

\section{2 - Práticas de gestão de pessoas em hotéis}

Nas seções seguintes são apresentadas referências teóricas sobre as áreas de Gestão de Pessoas e de Hotelaria. Diversos autores trabalham essas temáticas, principalmente definindo processos e operações específicas, uma vez que se referem a estudos e conhecimentos organizacionais. Com isso, optou-se por delimitar a revisão de literatura que aborda aquelas áreas sob as perspectivas que detalham processos específicos.

\subsection{1 - Processos de comunicação interna num contexto organizacional-hoteleiro}

Dentre as principais atribuições à gestão de pessoas em um hotel, destaca-se o exercício da comunicação eficaz, visto que tanto as expectativas dos proprietários e investidores, como as percepções dos hóspedes atendidos ilustram pontos extremos na realização das tarefas de todos os funcionários de um hotel. Essa realidade se evidencia no que propõem Hayes e Ninemeier (2005) e Davies (2001) ao elucidarem as principais responsabilidades de um gerente geral de hotel, enquanto profissional de posição estratégica para o sucesso de um negócio em hotelaria.

Assim sendo, é possível apontar que o gerente geral também deve apresentar competências pertinentes à gestão de pessoas, principalmente quando assumem o desafio de apresentar às equipes de hoteleiers as metas organizacionais do hotel, enquanto objetivos dos 
seus proprietários/investidores. Petrocchi (2002) acredita que "a qualidade da comunicação interna propiciará a conquista, a permanência e o desenvolvimento do quadro de colaboradores” de um hotel (PETROCCHI, 2002, p.51).

Todavia, para Gil (2006) uma comunicação só será eficaz quando o receptor realmente compreender o significado pretendido pelo emissor. No contexto de uma organização hoteleira, é possível identificar como “emissor” o gerente geral que deve apresentar as metas do hotel, e por “receptores” todos os funcionários que ali trabalham.

O referido autor argumenta que todos os gerentes, no contexto de uma organização, devem ser capazes de se comunicar, pois que precisam expressar suas idéias e planos às outras pessoas. Contudo, é preciso saber se comunicar. Embora essa habilidade seja inerente ao ser humano, não são todas as pessoas que dominam essa competência - é possível identificar barreiras à eficácia da comunicação. Essas são classificadas como “ruídos” que inviabilizam a compreensão do verdadeiro significado da mensagem emitida pelo comunicador, de modo a corromper a interpretação coerente aos propósitos da mensagem, por parte do receptor.

Portanto, para haver uma boa comunicação, para o mesmo autor, é fundamental saber ouvir, assimilar e interpretar o que é dito e expressado pela outra pessoa. Pode ser necessário solicitar à outra parte que se expresse, bem como oferecer condições para a realimentação desse processo de comunicar. Uma vez que variáveis como empatia, interesses e atitudes se inserem na compreensão dos processos de comunicação interna a uma organização, o referido autor defende que esses também representam focos de atuação à gestão de pessoas.

\subsection{2 - Recrutamento e seleção de hoteliers}

Tanto o recrutamento, como a seleção de pessoal, consiste na atração e identificação de candidatos cujos perfis e qualificações atendam às expectativas do bom desempenho de determinados cargos - exclusivamente aqueles que ainda precisam ser preenchidos. Nessa perspectiva, Petrocchi (2002) aponta como um dos principais requisitos para a seleção de hoteliers o perfil adequado para realizar atendimento ao público. Para tanto, Gil (2006) afirma que os critérios a serem avaliados num processo de recrutamento e seleção devem ser 
organizados e definidos quanto às suas prioridades e exigências quanto às atribuições do cargo.

Todavia, o quadro de funcionários em qualquer organização não se mantém estático. Segundo Marras (2000), o que definirá a freqüência dos serviços de recrutamento e seleção serão os índices de rotatividade, mudanças organizacionais, ou a expansão da organização. O índice de rotatividade mensura a quantidade de empregados desligados, em comparação ao quadro médio de efetivos.

A rotatividade de pessoal, conforme defende Gil (2006) é um indicador, também, da ineficiência das atividades de recrutamento e seleção, visto que é conseqüência de anteriores contratações de pessoas sem a devida qualificação.

Acerca dessa associação entre a qualidade da seleção de pessoas, e a determinação de profissionais qualificados, Petrocchi (2002) acredita que é no processo de recrutamento e seleção que se inicia, e se garante, o sucesso da organização hoteleira. Na visão do autor, as pessoas (hoteliers) contratadas devem apresentar o perfil adequado aos desafios de hospedagem.

Será com base na descrição de cargo que se poderá definir o perfil adequado do potencial - e futuro - funcionário a ser selecionado para assumi-lo. Na visão de Marras (2000) e Gil (2006), a descrição de cargos corresponde, assim, a um requisito essencial à eficiência das atividades de recrutamento e seleção, uma vez que fornece detalhamentos das tarefas envolvidas no desempenho esperado de uma determinada função, à qual um novo funcionário será recrutado e selecionado. Para o autor, a interface entre as atividades de descrição e análise de cargos com as de recrutamento e seleção deve "relacionar as atribuições e responsabilidades de cada cargo” (GIL, 2006, p.92).

Frente a essas concepções, Zavaglia (2006) define por objetivo de um processo de recrutamento e seleção a captação de pessoas para se engajarem no funcionamento da organização. Assim, a autora pontua que tal processo deve ser devidamente planejado, com base no levantamento e conhecimento exato das reais necessidades da organização, e execução com base na captação de pessoas no mercado de trabalho local. Com isso, é necessário avaliar se esse mercado oferece condições para suprir as demandas de pessoal da organização, ou se o próprio contexto interno dessa não apresenta potenciais recursos humanos, aptos a assumirem outros cargos. Esses aspectos podem orientar quanto à determinação pela realização de recrutamento interno, ou externo. 
Entende-se por recrutamento de pessoal a captação de recursos humanos no próprio ambiente interno da organização (a exemplo das possibilidades de potencial desenvolvimento de planos de carreiras) - o que se classifica como "recrutamento interno" - ou no ambiente externo àquela organização - definido por "recrutamento externo" -, gerando condições para o processo de seleção de pessoas para determinado cargo (MARRAS, 2000; FAISSAL et al, 2005; ZAVAGLIA, 2006). Será a partir da requisição de pessoal, emitida pelo coordenador/gerente de um determinado setor/departamento que precise preencher algum cargo de sua constituição, que se definirá o tipo de recrutamento a ser empreendido pelos profissionais de gestão de pessoas da organização.

Na concepção de que os departamentos/setores da organização devem ter suas respectivas constituições de equipes devidamente preenchidas, Petrocchi (2002) argumenta que o tamanho do empreendimento, isto é, a dimensão física do hotel, consiste em fator determinante para se definir a quantidade de funcionários necessários para se garantir a maior produtividade possível, entendendo que essa se representa na obtenção de receitas (índice de aquisição dos serviços oferecidos pelo hotel, por parte dos hóspedes) ideal para se cobrir os valores das entradas, da alocação de recursos (materiais e humanos), por parte da organização hoteleira para seu funcionamento. $\mathrm{O}$ autor aponta que o número de funcionários, devidamente contratados, corresponderá à constituição da estrutura organizacional do hotel. Assim, a maioria dos serviços de um hotel de pequeno porte, por exemplo, poderão ser realizados por um pequeno grupo de profissionais (podendo até incluir o proprietário nesse grupo), ao passo que grandes hotéis demandarão um número maior de funcionários que, por sua vez, devem ser distribuídos para setores específicos, garantindo o bom funcionamento - e sucesso no desempenho - organizacional.

Como foi explicitado anteriormente acerca da aplicação de um recrutamento externo, Hayes e Ninemeier (2005) afirmam que quando um grupo de investidores - ou empresários decide por construir e instalar um hotel em uma determinada localidade, é interessante para a economia daquele lugar que o empreendimento se baseie na contratação da mão de obra local, isto é, que o quadro de funcionários da organização hoteleira seja composto por habitantes da cidade (ou região) onde é sediada, cumprindo, assim, com a aplicação de um dos princípios mais importantes do desenvolvimento sustentável promovido por práticas de Turismo, conforme argumentam Ruschmann (1997), Arbache (2001), além de diretrizes do Ministério do Turismo (2005) cujos pressupostos integram a concepção da inserção social através do trabalho. Nessa perspectiva, para o desenvolvimento organizacional de um hotel, é 
interessante valorizar o saber local; isto é, os conhecimentos sobre a realidade da comunidade onde aquele hotel é construído e sediado.

O fato de se considerar o ambiente externo à organização como fonte para mão de obra para um hotel também é representada pela concepção de que este tipo de negócio é identificado como um dos elementos do sistema Turismo, conforme delimita Acerenza (2002). Além disso, Petrocchi (2002) aponta para a importância dos hoteliers terem conhecimento sobre os eventos que acontecem na sociedade onde o hotel é sediado, uma vez que os hóspedes atendidos são turistas que vieram conhecer os atrativos daquele lugar.

Conjugado aos objetivos de recrutamento, e como etapa sucessiva, Gil (2006) define por seleção de pessoal o exercício de comparações entre candidatos com perfis e qualificações adequadas à ocupação do cargo pretendido, frente às expectativas ao desempenho desse cargo, de modo a identificar qual seja o mais capacitado para alcançar a realização de tais expectativas.

Ao se obter um considerável quantitativo de candidatos à vaga (cargo) em aberto tanto por recrutamento interno, como externo - é necessário realizar uma triagem, comumente baseada na análise de currículos, ou inventário de talentos, dos candidatos. A partir dessa triagem se orientará ao início do processo de seleção. Após os candidatos serem recrutados, Zavaglia (2006) pontua que técnicas e procedimentos devem ser realizados para a escolha do candidato com perfil mais ideal à ocupação do cargo que tenha despertado para a solicitação de novas contratações de funcionário. O processo de seleção tem por objetivo principal, segundo a autora, identificar o indivíduo certo para o cargo certo, prevendo quais candidatos possivelmente terão maiores chances de sucesso, caso sejam contratados. Com isso, um dos maiores desafios da seleção de pessoal consiste em adequar o futuro - e novo - empregado ao cargo que assumirá, garantindo sua satisfação no exercício da nova função.

Nesse enfoque, aplicado ao contexto de uma organização, Marras (2000) e Gil (2006) compreendem por seleção de pessoal a adoção de uma metodologia, sob a qual os profissionais do RH escolherão, dentre candidatos recrutados e triados, quem assumirá o cargo em aberto, atendendo às demandas da organização. O foco desse processo, para a sua prática, está em tal metodologia, que deve contemplar comparações entre as exigências da função pretendida (conforme critérios resultantes da análise do cargo em aberto), e as características (conhecimentos, habilidades e atitudes, principalmente) do candidato que apresente o perfil ideal ao exercício daquela função. Portanto, faz-se necessário conhecer e 
avaliar os diferentes perfis dos candidatos que competem para a referida oportunidade de trabalho.

Assim sendo, a metodologia para seleção de pessoal deve abranger procedimentos que possibilitem conhecer as características dos candidatos. Esses procedimentos, segundo Faissal et al (2005), se baseiam, principalmente, em entrevistas, testes de conhecimento e testes práticos, dinâmicas de grupo. Todos esses procedimentos, no entanto, devem ser aplicados com o objetivo principal de se analisar o comportamento dos candidatos a emprego, possibilitando estabelecer comparações entre as personalidades destes com o perfil desejado pela empresa ao exercício da função à qual se realiza o processo de recrutamento e seleção.

Para complementar a análise comportamental dos candidatos, visando melhor orientar a tomada de decisão sobre quem será o escolhido a se inserir no quadro de funcionários da organização, Marras (2000), Faissal et al (2005), Zavaglia (2006) e Gil (2006) apontam que dentre os testes que complementam um processo decisório à seleção de pessoal, existem os testes práticos (que avaliam determinados conhecimentos, técnicas ou práticas de tarefas específicas), situacionais (avaliam como os candidatos agiriam em determinadas situações, comuns ao trabalho), psicológicos (somente aplicados por psicólogos, mensuram aptidões e traços de personalidade) e grafológicos (constituídos por análise da escrita individual de cada candidato, capaz de fornecer informações sobre sua personalidade).

Gil (2006) afirma que avaliar o candidato com base em observações e registros de tudo o que tenha sido apresentado em cada procedimento da seleção de pessoal possibilita prever comportamentos do candidato selecionado no contexto de trabalho, especialmente no exercício das funções para a qual fora selecionado. Todavia, esse tipo de avaliação não garante a plena satisfação, resultante de todo o processo seletivo. Portanto, deve se basear na interpretação de todos os dados obtidos ao longo de todo o processo, de modo a fornecer a identificação do perfil mais adequado, com certa margem de segurança, para a contratação mais vantajosa à organização.

\subsection{3 - Descrição e análise de cargos nos hotéis}

Por “cargo”, Chiavenato (1999) compreende o conjunto de tarefas (ações cotidianas ao funcionamento da organização) e atribuições (atividades mais complexas, dinâmicas e de 
finalidades administrativas) delegadas para as pessoas da organização, de modo a especificar as responsabilidades e desempenhos de cada funcionário. Portanto, a análise e descrição de cargos se associam com os processos de recrutamento e seleção - ao orientar a determinação do perfil mais adequado às específicas funções envolvidas num contexto organizacional. Além disso, por possibilitar comparações entre as expectativas da organização, e as performances individuais, a avaliação de cargos orienta à identificação nas necessidades de treinamento e desenvolvimento, bem como destacar desempenhos que superam as expectativas organizacionais para pessoas que mereçam prêmios, e outros incentivos, para se manterem inseridas no quadro de funcionários efetivos.

Gil (2006) aponta que a definição de cargos não se baseia somente na descrição de tarefas, mas também nas regras e condutas - comportamentos - de quem assume o cargo. Prática já realizada desde os tempos de Taylor (de acordo com os princípios da Teoria da Administração Científica, a superespecialização das tarefas possibilitava supervisionar o trabalho, servindo como descrição do que cada funcionário deveria realizar), apresentou mudanças com o advento da Teoria das Relações Humanas (que despertou às associações entre descrição de tarefas com fatores sociais e psicológicos dos funcionários, apontando a busca pelo crescimento individual através do trabalho), e atualmente se consolida com o modelo das características do trabalho, segundo o qual a descrição de cargos não se mantém estática, devendo se adequar às mudanças impostas à organização, e às maneiras - ou possibilidades - de se aprimorar a execução de tarefas.

É possível observar que uma análise de cargos bem detalhada orienta as atividades da gestão de pessoas. Uma vez que envolve o levantamento de informações gerais das tarefas e atribuições, a descrição de cargos consiste em expor como cada funcionário realiza seu trabalho. Portanto, conforme apontam alguns autores (CHIAVENATO, 1999; MARRAS, 2000; ZAVAGLIA, 2006) especificar um cargo corresponde à identificação de conhecimentos, habilidades e atitudes (CHAs), domínios e responsabilidades requisitadas de um funcionário.

Nesse enfoque, Gil (2006) aponta que as informações necessárias para a análise e descrição de cargos podem ser obtidas através de observações diretas (o analista vê como as tarefas e atribuições do cargo são executadas no seu próprio contexto de trabalho, além de verificar quais documentos regularizam o cargo), questionários (focados às características dos cargos, e aplicados aos seus ocupantes) e entrevistas (interações diretas entre o analista e empregado para se obter dados mais apropriados, possibilitando a elucidação de dúvidas no 
contato direto). Esses métodos para análise e descrição de cargos também fornecem subsídios às operações de avaliação de desempenho, bem como identificar talentos no quadro de funcionários, possibilitando à organização oferecer o desenvolvimento de planos de carreira.

Segundo Hayes e Ninemeier (2005), o profissional que atua na indústria hoteleira pode desenvolver plano de carreira. Esses autores argumentam que os níveis gerenciais de um hotel apresentam várias posições (cargos) que um empregado capacitado pode assumir.

Por plano de carreira, a autora Zavaglia (2006) compreende o desenvolvimento de pessoal - atribuição à gestão de pessoas que consiste em promover o crescimento de um funcionário, com repercussões ao desenvolvimento da organização. Todavia, a gestão do desenvolvimento de pessoas, segundo a autora, deve se basear em ações de longo prazo, sob o objetivo de se aperfeiçoar as capacidades das pessoas, além de valorizá-las ao possibilitar a motivação para o trabalho.

\subsection{4 - O desenvolvimento de carreiras para hoteliers}

O ideal de qualquer proposta de desenvolvimento de pessoal, conforme afirma Zavaglia (2006), deve se concentrar na suposição de que a aquisição de novos conhecimentos - e suas respectivas aplicações no trabalho - culminarão no melhor desempenho profissional; isto é, promoverão significativas contribuições ao sucesso da organização, resultantes de tarefas executadas com excelência pelos seus funcionários.

Assim, a referida autora acredita que propor o desenvolvimento de planos de carreira corresponde a uma medida capaz de promover vantagens competitivas à organização, uma vez que ao despertar no quadro de funcionários efetivos a percepção de se aprimorar talentos, e se comprometerem com a realização das metas organizacionais a longo prazo, os empregados buscarão crescer junto com a empresa. Essa perspectiva sustenta a concentração de esforços com a motivação ao se promoverem ambos os crescimentos e desenvolvimentos: o individual (profissional) e o geral (da organização como um todo).

Frente à abordagem do desenvolvimento de um plano de carreira em hotéis, Davies (2001) aponta como uma das principais atribuições aos profissionais de gestão de pessoas em hotelaria selecionar os funcionários internos para ascensão de carreira, bem como controlar as transferências de cargos. 
Visando a aplicação de programas e/ou propostas para planos de carreiras, Zavaglia (2006) aponta que existem três maneiras para tal medida: estrutura em linha (definida por uma única direção, orientando a ascensão de cargos determinados por hierarquias e níveis de autonomia), estruturas em forma paralela ou Y (oferecendo maior flexibilidade ao funcionário poder definir e criar a direção de suas respectivas carreiras, uma vez que decide pela ocupação de cargos orientada pela natureza profissional, ou gerencial), e estrutura em rede (quando diferentes acessos a novas posições são oferecidos não se baseando somente em ascensões hierárquicas de autonomia).

Todavia, Gil (2006) aponta que a implantação de planos de carreiras deve ser previamente definida, especificando: características dos cargos que componham uma carreira a ser percorrida; requisitos às ascensões e níveis da carreira; e quais instrumentos de avaliação de cargos e de desempenho podem viabilizar a gestão de um plano de carreira.

\subsection{5 - Treinamento e desenvolvimento em hotelaria}

Frente ao desafio de maximizar a produtividade dos hoteliers para alcançar diferenciais estratégicos à organização hoteleira, Davies (2001) aponta que a tarefa de implementar e supervisionar programas de treinamento e desenvolvimento representam significativas contribuições da gestão de pessoas às estratégias em hotelaria.

Um programa de treinamento e desenvolvimento, para ser implantado em uma organização, deve apresentar objetivos bem determinados, conforme afirma Zavaglia (2006). Para tanto, faz-se necessário identificar o potencial de aprendizagem e a capacidade produtiva dos funcionários, de modo a se definir o que deve ser aprimorado em termos de execução das tarefas atribuídas aos diferentes cargos, bem como quais conhecimentos e habilidades precisam ser adquiridos, resultando na consolidação de novas competências. Esse princípio também se aplica aos hotéis, segundo Rutherford (2004), de modo que treinamentos oferecidos aos hoteliers devem visar o desenvolvimento de competências desses, tornando-os mais produtivos, criativos e inovadores, resultando na agregação de valores à organização hoteleira.

Milioni (2006) concebe a área de treinamento e desenvolvimento (T\&D), enquanto prática em Gestão de Pessoas, como exercício de educação empresarial que se estende desde o 
ideal de ajustar as competências humanas à realização de tarefas fiel à determinação de estratégias organizacionais, incluindo o aprimoramento e impactos percebidos em outros processos e operações empresariais. Para tanto, o autor argumenta que a execução de um programa de T\&D deve ser conseqüente da definição exata e segura dos recursos e métodos necessários, garantindo bons resultados à organização em que se aplica aquele programa. $\mathrm{Na}$ visão do referido autor, a educação empresarial deve ser concebida como um investimento capaz de gerar retornos (financeiros e de melhoria na produtividade) à organização.

Na perspectiva de se definir métodos, processos e recursos necessários à eficácia de um programa de T\&D, a autora Felippe (2004) associa a etapa de identificação das necessidades de treinamento à condição de se definir os objetivos específicos e as expectativas para tal programa, de modo a prever e determinar a qualidade para sua execução e resultados sobre o contexto em que é realizado. Para tanto, identificar as necessidades de treinamento, segundo a autora, constitui a ação de representar a situação atual da empresa (semelhante a um diagnóstico organizacional), e projetar como se deseja obter uma nova realidade à mesma, em termos de aprimoramento das competências humanas ali inseridas.

Assim como Petrocchi (2002) e Pimenta (2006) defendem que a gestão de hotéis objetiva definir diferenciais estratégicos frente à concorrência de mercado, tendo por base a determinação da qualidade percebida pelos hóspedes atendidos, enquanto clientes que adquirem serviços de hospedagem, a autora Felippe (2006) argumenta que as variáveis referentes à: percepção de valor dos produtos/serviços, por parte dos clientes atendidos, diferenciações entre empresas concorrentes e capacidades de expansão organizacional, são indicadores de competências capazes de serem identificadas como necessidades de T\&D. De modo geral, a identificação e levantamento de tais necessidades devem ser compatíveis às estratégias e metas definidas para a organização - a exemplo das expectativas dos investidores de um empreendimento hoteleiro.

Sobre o planejamento de programas de T\&D, Hayes e Ninemeier (2005) argumentam que as necessidades de treinamento e experiências requeridas de um gerente geral de hotel são diretamente relacionadas com o tamanho e estrutura da empresa hoteleira a ser administrada. Em outras palavras, embora o desafio de administrar seja o mesmo, a preparação gerencial de um resort, por exemplo, se diferencia das necessidades de gestão de um hotel de pequeno porte. A preparação, formação e aprimoramento profissional para um gerente geral de hotel podem ser desenvolvidas através de capacitações oferecidas em programas de educação formal (com fins de formar tecnólogos, bacharelados, especialistas, mestres ou doutores), de 
treinamento on the job (isto é, fornecer aos profissionais, em seu próprio local de trabalho, a aquisição de novos conhecimentos, experiências práticas e condições para implantarem melhorias nas execuções de suas tarefas), além dos programas de desenvolvimento profissional. Ou seja, quando os próprios gerentes gerais, conscientes das novidades e atualizações em hotelaria, aplicam recursos ou adotam medidas (como se filiar a sindicatos, fundações, associações, e congressos, por exemplo) para capacitar as equipes de trabalho que integram a organização onde atuam, consolida-se a oportunidade para a execução de um programa de T\&D na organização hoteleira.

Todavia, a gestão de T\&D não se restringe somente às etapas de planejamento e execução. Milioni (2004), Navarro e Pomi (2004) enfatizam que os resultados de um treinamento devem ser mensurados e representados por valores monetários e por indicadores de desempenho (comumente baseados em comparações na performance de um funcionário antes de ser treinado, e após o treinamento), de modo que a gestão desse tipo de programa exige o conhecimento sobre retornos de investimentos às organizações, uma vez que capacitar funcionários representa um investimento da empresa.

Nessa perspectiva, para se conhecer os impactos e efeitos de um programa de treinamento e desenvolvimento, compreendendo por "efeitos a longo prazo" as conseqüências da realização daquele T\&D no contexto da organização, e a comparação de tais efeitos com os propósitos apontados no levantamento das necessidades identificadas (ainda no planejamento do programa), Palmeira (2004) e Borges-Andrade (2006) apontam que existem meios de se avaliar se os treinandos realmente adquiriram novos conhecimentos e habilidades, bem como se aplicam as novas competências no contexto de trabalho após concluírem a participação em tal tipo de programa. Tais avaliações, afirmam aqueles autores, podem se basear em observações, entrevistas, ou até mesmo questionamentos apresentados aos funcionários treinados, e aos seus pares nas equipes que constituem (supervisores, colegas, ou subordinados). Essa concepção também se aplica à composição de uma equipe de hoteliers.

Diversos autores (Gil, 2006; Zavaglia, 2006; Milioni, 2004; e Palmeira, 2004) compartilham a afirmação de que caberá à Gestão de Pessoas avaliar se a execução dos programas de T\&D cumprem o objetivo de promoverem novas competências que vinculem os funcionários ao comprometimento com o trabalho e geração de novos valores à organização. 


\subsection{6 - Avaliações de desempenho de hoteliers}

Uma avaliação de desempenho, assim como qualquer prática de gestão de pessoas, deve ser planejada de modo que, anterior à sua aplicação, sejam definidas quais ações serão implementadas em decorrência de seus resultados, sejam positivos ou negativos (a exemplo de uma promoção salarial, ou de uma demissão).

Marras (2000) define por desempenho o ato de executar alguma tarefa, considerando a combinação da motivação (o “querer fazer”) com a cognição (o "saber fazer”) num processo de produção. Assim, por avaliação de desempenho, o autor entende a mensuração de todos os resultados - por meios quantitativos, ou qualitativos - de tudo o que é realizado e produzido por um empregado, avaliando o que esse promove como contribuição (ou valor) para a organização na qual se insere.

No contexto de uma organização hoteleira - e compreendendo que o desempenho da equipe de hoteliers será fator decisivo à garantia do retorno sobre o investimento dos investidores de tal tipo de empreendimento -, é significativo avaliar o desempenho daqueles funcionários. Petrocchi (2002) afirma que essa avaliação não somente possibilita mensurar e acompanhar a qualidade dos serviços de hospedagem, conforme prestados no cotidiano de um hotel, como também garantir que a produtividade da organização hoteleira, como um todo, gera lucro e retorno sobre seus investimentos. Para tanto:

\footnotetext{
O hotel precisa fazer com que seus empregados trabalhem motivados. Trabalhem com prazer. Afinal, somente dessa forma o hotel atingirá um padrão de serviços que lhe dê competitividade ou condições de sobreviver no mercado. (PETROCCHI ,2002, p.128)
}

É preciso que se aponte, conforme feito por Marras (2000), que existem “vulnerabilidades” numa avaliação de desempenho. A principal delas se concentra na subjetividade de quem julga como a outra pessoa realiza suas atividades. Todavia, tal tipo de avaliação pode ser devidamente planejada e aplicada de acordo com metodologias que, por sua vez, tenham por foco orientar a mensuração de realizações e contribuições humanas voltadas para resultados, ou na observação e identificação de conhecimentos envolvidos na execução de uma tarefa, eliminando as influências subjetivas do avaliador sobre a realização de tal tipo de processo. 
Dentre os possíveis métodos para uma avaliação de desempenho, Gil (2006) e Zavaglia (2006) destacam a adoção de instrumentos, como planilhas, gráficos e tabelas nas quais, através de pontuações, o avaliador registra as impressões que teve de um empregado ao observar como esse trabalha (dentre esses métodos, o autor identifica o método de escalas gráficas, e de incidentes críticos). Porém, também existem os métodos baseados em comparações do que é produzido por diferentes empregados, abordando e julgando como executam suas tarefas.

Como uma alternativa para se superar a possível influência da subjetividade do avaliador, Marras (2000) identifica o “método de escolha forçada” capaz de obrigar aquele avaliador a atribuir determinadas frases, previamente definidas, aos julgados, de modo que a avaliação se realiza por meio da associação do desempenho do funcionário avaliado com a frase que o caracteriza.

Embora com foco sobre os impactos de um programa de treinamento, mas também apontando como perspectiva possível de ser adotada numa avaliação de desempenho, Pilati e Borges-Andrade (2006) afirmam que o comportamento no cargo pode ser avaliado através de observações (limitadas ao que pode ser observado, durante um período, e apenas enquanto o observador está presente no contexto observado), ou perguntas - que poderão ser respondidas pelos próprios funcionários (autoavaliação), ou pelos seus subordinados e colegas (heteroavaliação). Assim sendo, a avaliação do tipo 360 graus pode ser entendida como uma "heteroavaliação".

A “avaliação 360 graus” - conforme definida por Marras (2000) - consiste no julgamento do desempenho de um determinado funcionário por parte de todas as outras pessoas (supervisores, pares, subordinados, fornecedores e clientes) com quem se relaciona ao realizar seu trabalho.

Uma vez que ao final do processo, o avaliador deve apresentar feedback dos pontos fortes e fracos de cada funcionário avaliado, fundamentando seus julgamentos e comprovando seus pontos de vista, Marras (2000) afirma que as tipologias de avaliações de desempenho (com exceção ao método de 360 graus) geralmente são criticadas devido às posturas assumidas após sua aplicação, visto que seus efeitos podem culminar num possível distanciamento entre os avaliadores, supervisores e avaliados. Quando o avaliador é o próprio supervisor direto, o funcionário avaliado dificilmente acreditará na oportunidade de 
argumentar sobre seu próprio desempenho conforme avaliado, e isso pode impactar no seu comprometimento ao trabalho.

É importante, portanto, que a avaliação de desempenho se realize através de ações conjuntas entre as partes envolvidas, com argumentos exatos e compreensíveis, e com transparências nos tratamentos aos participantes. Vale ressaltar que o ideal daquela avaliação centra-se em promover melhorias à organização, de forma a beneficiar e fortalecer as relações entre os funcionários avaliados.

\subsection{7 - Programas de qualidade de vida no trabalho em organizações hoteleiras}

A qualidade de vida no trabalho pode ser entendida como uma responsabilidade social da organização, na qual seja implantada sob a forma de programas. Zavaglia (2006) concebe que a implantação de um programa de qualidade de vida no trabalho (QVT), se justifica porque "contribui para que a organização repense antigas formas de trabalho, visando com isso o incremento do grau de satisfação das pessoas e da produtividade da organização" (p.127).

Fernandes (1996) define o termo "qualidade de vida no trabalho" como:

(...) gestão dinâmica e contigencial de fatores físicos, tecnológicos e sociopsicológicos que afetam a cultura e renovam o clima organizacional, refletindo-se no bem-estar do trabalhador e na produtividade das empresas" (FERNANDES, 1996, p.45-46).

Assim, a gestão da qualidade de vida no trabalho tem como princípio promover um ambiente de trabalho saudável, de forma a contribuir para a maior participação e colaboração das pessoas envolvidas nos processos internos das organizações.

Para Davies (2001) cabe aos profissionais da área de Gestão de Pessoas, em um hotel, assegurar que as equipes de funcionários se deparem com condições que promovam satisfação à realização do trabalho ao colaborarem para o sucesso organizacional frente ao seu objetivo de oferecer qualidade nos serviços de hospedagem. Para esse fim, pode ser extremamente válida a elaboração e implementação de programas de qualidade de vida no trabalho. 
Elucidando os conceitos de qualidade de vida no trabalho, Zavaglia (2006) aponta que é comum constatar por cobranças feitas, pelas organizações, às pessoas: obtenção de resultados de curto prazo, desenvolvimento de novas competências, capacidade de produzir mais e melhor, etc. Em contrapartida, verifica-se o agravamento de estresse e doenças ocupacionais sobre os funcionários, culminando na geração de um ambiente de trabalho desumano. Assim, os novos desafios encontrados no cenário organizacional, levam as empresas a intensificarem suas competitividades, exigências sobre os potenciais humanos, bem como o aumento dos acidentes e doenças conseqüentes do trabalho. Para a referida autora, tais condições implicam na constatação de que é necessária uma reavaliação das normas, condutas, e valores de uma empresa. Entretanto é fundamental que os benefícios de um programam de qualidade de vida no trabalho (intervenção para se promover saúde e educação como estratégias capazes de alavancar melhores índices de produtividade) sejam compreendidos de forma que atendam tanto aos funcionários como à própria organização, refletindo na mudança de valores internos.

Limongi-França e Zaima (2004) apontam que as organizações reconhecem como principal dificuldade, para a implantação de um programa de QVT, o fato de que este processo requer a participação de todas as pessoas nas tomadas de decisão sobre os processos que realizam num mesmo contexto, o que culminará, inevitavelmente, na mudança de toda a cultura organizacional, visto que isto revelaria ações voltadas às melhorias e inovações tecnológicas, gerenciais e estruturais em todo o nível microorganizacional.

Assim como a cultura é específica para cada empresa, os programas de QVT também irão variar, de acordo com as reais necessidades de cada organização, de forma que caberá aos profissionais de RH, ou Gestão de Pessoas, definirem quais sejam, de fato, as exigências para as melhorias, humanização (oferecer condições adequadas, evitando tensões, atividades de risco e perigo, e garantindo o exercício da cidadania), e promoção do bem-estar para a realização de um trabalho saudável na organização. 


\section{IV - MÉTODOS DA PESQUISA}

A partir das associações entre potenciais contribuições da Gestão de Pessoas ao comprometimento dos empregados de um hotel e à consolidação de diferenciais estratégicos e de vantagens competitivas de mercado, com a preocupação de se garantir o retorno aos investimentos dos proprietários e demais atribuições ao gerente geral de hotéis, revelou-se válido o questionamento: Como se constroem as práticas de Gestão de Pessoas nos hotéis de Juiz de Fora?

Partindo do interesse em buscar respostas àquele questionamento, e considerando-o tema para trabalho científico, foi realizada esta pesquisa. Com base em levantamentos bibliográficos que abordam conhecimentos das áreas de Gestão de Pessoas e Hotelaria, determinou-se a intenção de se verificar as potencialidades do gerenciamento do capital humano nos hotéis. Para tanto, foi realizada coleta de dados primários por meio de questionário estruturado aplicado ao grupo das organizações que compõem o setor hoteleiro de Juiz de Fora. A partir daquele instrumento, pretendeu-se conhecer como se consolidam as práticas de gestão de pessoas e como essas são percebidas pelos gerentes gerais de hotelaria em Juiz de Fora.

Nos últimos quatro anos, foram implantadas, na cidade de Juiz de Fora, novas instituições de ensino superior, bem como a construção de um novo shopping center, inaugurado no dia 22 de abril de 2008, cuja dimensão e estrutura não somente possibilitou o ingresso de multimarcas no comércio da cidade, como também estabeleceu mudanças nos hábitos e comportamentos do consumidor juizforano. Esses fatores não somente podem ser apontados como pré-estimativas - ou determinantes - à expansão comercial e de prestação de serviços (incluindo a área de Educação) na cidade, como também evidenciam o aumento de sua potencial atratividade turística, especialmente por aqueles que visitam a cidade para fins de negócios, ou que objetivam desenvolver suas respectivas formações acadêmicas.

Além disso, Juiz de Fora também apresenta potencial de atratividade turística devido a programações sociais e culturais, a exemplo do JF Folia, da Festa Country de Juiz de Fora, do Rainbown Fest e Miss Brasil Gay, da Campanha de Popularização do Teatro e do Festival Internacional de Música Barroca - eventos esses que repercutem em consideráveis índices de geração de renda às empresas de turismo vinculadas à cidade mineira, principalmente sob a forma de hospedagens nos hotéis juizforanos. 


\section{1 - Delineamento da pesquisa}

Frente à contextualização sobre como as organizações hoteleiras podem colaborar ao desenvolvimento econômico em Juiz de Fora, partiu-se ao interesse em se investigar como se consolidam as práticas de gestão de pessoas nos hotéis dessa cidade.

Além do respaldo da revisão teórica conforme já apresentada, determinou-se a realização da pesquisa de campo para o desenvolvimento desse estudo, orientado a esclarecer questionamentos formulados sobre as práticas de gestão de pessoas nos hotéis juizforanos, revelando o que ocorre na realidade cotidiana das organizações pesquisadas.

Vale ressaltar que as variáveis pertinentes ao comprometimento das pessoas especificamente dos profissionais que se inserem nas organizações hoteleiras: os hoteliers representaram os principais elementos a serem investigados. Porém, a partir da premissa de que a gestão de pessoas deve contribuir para a geração de diferenciais estratégicos a um hotel, aqueles elementos se inserem na projeção das atividades de tal área organizacional. Com isso, as questões que estruturaram o instrumento para coleta de dados se basearam no objetivo de se aferir quais são, de fato, as operações empreendidas pela área de gestão de pessoas nos hotéis, exclusivamente referentes a: programas de recrutamento e seleção, análise e descrição de cargos, treinamento e desenvolvimento, avaliações de desempenho e qualidade de vida no trabalho.

Estimou-se que a efetiva adoção e realização daqueles programas, para gestão de pessoas, pudesse ser identificada como contribuição à determinação de diferenciais estratégicos para uma organização integrante do setor hoteleiro de Juiz de Fora.

Assim sendo, a coleta de dados, para subsidiar as associações da área de gestão de pessoas à hotelaria e suas implicações à determinação de vantagens competitivas no mercado de turismo, ocorreu no período de 18 de abril de 2009 a 11 de junho de 2009, através da aplicação do instrumento da pesquisa (questionário estruturado, composto por dez perguntas) aos gerentes gerais de hotéis juizforanos.

Embora a expectativa inicial tenha se baseado no levantamento de dados advindos de todos os vinte e quatro hotéis, conforme registros da Associação para o Desenvolvimento do Turismo de Juiz de Fora e Região - a “Juiz de Fora e Região Convention \& Vistors Bureau” (Anexo A), somente onze participaram da realização da coleta de dados primários, uma vez que seus respectivos gerentes consentiram em colaborar para esse estudo. 
Conjugada a revisão de literatura - que conciliou as áreas de Gestão de Pessoas e Hotelaria - à realização da coleta de dados, define-se que esse estudo assumiu o caráter de pesquisa do tipo documental (uma vez realizado levantamento de bibliografias), transversal (aplicada em um só momento) descritiva (ao ter como base a análise de trabalhos já publicados por outros pesquisadores em consideração aos mesmos temas abordados no presente estudo: Gestão de Pessoas e Hotelaria) e exploratória (ao ter se buscado aspectos de uma realidade investigada; no caso, as práticas de gestão de pessoas nos hotéis juizforanos).

\section{2 - Descrição das variáveis da pesquisa}

A partir da aplicação de questionários aos gerentes do setor hoteleiro de Juiz de Fora, objetivou-se conhecer como aqueles concebem as práticas de gestão de pessoas nas respectivas organizações que gerenciam. Embora não se enquadrem, diretamente, nas equipes de “Administração de Recursos Humanos", ou de "Gestão de Pessoas”, acreditou-se que questionar a percepção daqueles gerentes às práticas referentes a essa área possibilitaria a identificação sobre como são promovidos diferenciais estratégicos de um hotel a partir da observação e valorização de seu capital humano.

Assim sendo, foram apresentadas questões orientadas a definir se realmente são aplicados ou oferecidos - além de conhecer, identificar e compreender como se realizam - no cotidiano dos hotéis pesquisados, programas de:

$\rightarrow$ Recrutamento e seleção;

$\rightarrow$ Análise e descrição de cargos;

$\rightarrow$ Planos de carreira;

$\rightarrow$ Treinamentos;

$\rightarrow$ Avaliações de desempenho;

$\rightarrow$ Motivação e Qualidade de vida no trabalho;

$\rightarrow$ Qualidade na prestação dos serviços de hospedagem.

Além dessas variantes, também foi objetivo da pesquisa de campo definir se as estruturas dos hotéis pesquisados apresentam um departamento, ou setor próprio, para gestão 
de pessoas, e se essa área corresponde à geração de valor e vantagem competitiva àquelas organizações frente ao mercado de Turismo.

Todas essas variáveis puderam ser conhecidas a partir da perspectiva dos gerentes gerais de hotéis, uma vez que o instrumento para coleta de dados fora aplicado a esses profissionais. Acreditou-se que se o questionário tivesse sido aplicado diretamente aos profissionais da área de gestão de pessoas, esses superestimariam suas próprias realizações.

Uma vez que os gerentes gerais assumem posição intermediária entre as expectativas dos proprietários e investidores de um empreendimento hoteleiro e a execução de tarefas dos hoteliers que operacionalizam o funcionamento do hotel, optou-se pela escolha daqueles gerentes como “fonte” para a perspectiva de que a gestão de pessoas assume caráter estratégico na administração hoteleira.

Com base nessas perspectivas, foi possível definir enquanto "variável critério”, isto é, a principal característica que se pretendeu pesquisar: como se realizam as atividades da área de gestão de pessoas nos hotéis juizforanos pesquisados.

A partir da análise daquelas atividades, se determinou por “variável dependente” a contribuição que representam para a definição de diferenciais estratégicos ao hotel em que são praticadas. Por “variável independente” se definiu a possível afirmação, por parte dos gerentes que responderam ao questionário da pesquisa, de que a área de gestão de pessoas não apresenta nenhuma contribuição, ou geração de valor ao negócio hoteleiro. Essas variáveis puderam ser devidamente trabalhadas na análise da questão dez (representada no Gráfico 10, e na Tabela 10) que integrou o instrumento da pesquisa.

\section{3 - Dificuldades operacionais}

Uma vez que foi necessário estar presente na cidade de Juiz de Fora, para fins de realização da coleta de dados (conforme planejamento do desenvolvimento dessa pesquisa), a primeira visita a um hotel juizforano ocorreu no dia 18 de abril de 2009, com o objetivo de apresentar a proposta deste estudo, bem como determinar, junto ao gerente geral que responderia ao questionário/instrumento da pesquisa, qual seria a melhor data para essa aplicação. Todavia, nas primeiras tentativas de se apresentar os propósitos desta pesquisa, não 
fora possível obter êxito, visto que não era permitido ao pesquisador ter acesso e contato direto com o público pretendido, ou seja, com os gerentes dos primeiros hotéis visitados.

No período de 18 de abril de 2009 a 13 de maio de 2009 foram realizadas, ao todo, vinte e sete visitas a treze hotéis sediados em Juiz de Fora. Porém, em todas essas tentativas de contato, nenhuma recepção (enquanto departamento operacional de um hotel) autorizou o acesso do pesquisador aos departamentos administrativos do hotel. Foi possível estimar que os recepcionistas (enquanto categoria de hoteliers) daqueles hotéis recebem ordens para não autorizar tal tipo de contato, tampouco possibilitar a aquisição de informações para fins de pesquisa.

Constatada tal impossibilidade, no dia 13 de maio de 2009 o pesquisador buscou auxílio à Secretaria de Planejamento e Desenvolvimento Econômico, Núcleo de Turismo da Prefeitura Municipal de Juiz de Fora. Ao manifestar as dificuldades para a realização desta pesquisa a uma das secretárias daquele núcleo, o pesquisador foi orientado a buscar o auxílio da Juiz de Fora e Região Convention \& Visitors Bureau, associação à qual se filiam os principais hotéis juizforanos.

Assim sendo, na mesma data o pesquisador se apresentou àquela associação, solicitando a relação de hotéis da cidade, bem como questionou se seria possível obter uma “carta de apresentação” que servisse como documento à validação dos propósitos da pesquisa. No dia seguinte àquela data (14 de maio), a gerente da associação Juiz de Fora e Região Convention \& Visitors Bureau enviou um e-mail ao pesquisador, afirmando que não poderia emitir tal tipo de documento para validação e/ou autorização à realização da pesquisa, mas informando a relação dos vinte e quatro hotéis filiados que representariam o universo para este estudo. Além dos nomes dos hotéis, o e-mail também continha a relação de endereços eletrônicos para tentativa de contato virtual com os representantes de cada uma daquelas organizações hoteleiras (o e-mail constando a relação emitida pela Juiz de Fora e Região Convention \& Visitors Bureau é apresentado no “Anexo A”).

Com posse dessas informações, o pesquisador enviou o questionário/instrumento desta pesquisa sob a forma de arquivo anexo para cada um dos e-mails daqueles hotéis, constando a apresentação de intenções e propósitos à realização deste estudo. Um modelo semelhante ao e-mail enviado aos representantes dos vinte e quatro hotéis que integraram o universo definido, pode ser visto no “Apêndice B”. Inclusive esse modelo apresenta o conteúdo 
comum às vinte e quatro mensagens enviadas, por correio eletrônico, aos vinte e quatro representantes dos hotéis de Juiz de Fora.

Todavia, até o dia 11 de junho de 2009, somente dois gerentes responderam o e-mail enviado pelo pesquisador, constando o questionário devidamente preenchido em anexo.

Em consideração a essas dificuldades operacionais ao estudo exploratório, o pesquisador adotou por estratégia buscar contatos de parentes e amigos de profissionais que atuam nos hotéis juizforanos. Através dessa medida, foi possível alcançar o contato direto, bem como aplicar o questionário/instrumento da pesquisa com nove gerentes gerais daquele grupo de hotéis, consolidando, assim, o grupo de onze participantes e colaboradores ao desenvolvimento desta pesquisa.

\section{4 - População}

A princípio, para a realização dessa pesquisa, era de grande interesse - e vontade - do pesquisador conseguir aplicar o questionário a todos os vinte e quatro gerentes, representantes do universo dos hotéis sediados em Juiz de Fora, conforme registros de filiação "Juiz de Fora e Região Convention \& Visitors Bureau”. Entretanto, a partir das dificuldades operacionais supracitadas, foi possível realizar a coleta de dados primários somente em onze hotéis que compreendem aquele universo de vinte e quatro organizações.

Assim sendo, essa pesquisa se concentrou na análise das informações fornecidas pelos onze hotéis que colaboraram ao desenvolvimento deste estudo.

\section{5 - Procedimentos e instrumento utilizados na coleta e análise de dados}

Conforme já elucidado, a coleta de dados deste estudo se baseou na aplicação de um questionário estruturado (isto é, composto apenas por questões fechadas, de resposta direta a alternativas predeterminadas) aos gerentes gerais de hotéis juizforanos.

O instrumento foi elaborado com o propósito de se conhecer as práticas de gestão de pessoas nas organizações hoteleiras de Juiz de Fora. Assim, cada uma de suas questões tinha 
por foco avaliar algum critério referente àquelas práticas de âmbito organizacional. Ao todo foram elaboradas dez perguntas, com respectivos objetivos:

Primeira questão: a partir do levantamento de referências bibliográficas sobre Gestão Hoteleira (devidamente apresentado no Capítulo 1 do Referencial Teórico desta pesquisa), buscou-se conhecer como os serviços de hospedagem são classificados nos hotéis pesquisados.

A segunda questão se subdividiu, considerando a possibilidade de não haver um departamento - ou setor - específico para Gestão de Pessoas em algum hotel pesquisado. Portanto, essa questão se centrou em conhecer, se existia, ou não, uma equipe, ou departamento específico para aquela área organizacional.

A terceira, quarta, quinta, sexta, sétima e oitava questões objetivavam conhecer como se aplicariam, nos hotéis investigados, atividades que correspondessem, respectivamente, às atribuições da gestão de pessoas: recrutamento e seleção, planos de carreiras, treinamentos e desenvolvimento, avaliações de desempenho e descrição de cargos.

A nona questão se concentrou em conhecer se os hotéis utilizam ferramentas para a mensuração da qualidade dos serviços que oferecem ou, ainda, se existe a preocupação com a motivação e qualidade de vida no trabalho dos hoteliers. Por fim, a décima e última questão buscava identificar como os gerentes gerais concebem as práticas de gestão de pessoas nos hotéis que gerenciam.

Nessa última pergunta, inserida no instrumento, objetivou-se relacionar a efetiva prática, na realidade e cotidiano das organizações hoteleiras, às premissas de que a área de gestão de pessoas assume caráter estratégico à administração de um hotel.

A constituição do instrumento para coleta de dados, elaborado para esta pesquisa, pode ser visto no "Apêndice A”, no mesmo modelo com que fora aplicado aos gerentes gerais de hotéis que participaram deste estudo.

Consolidada a coleta de dados primários, esses foram tabulados em planilhas, através do software Microsoft Excel, e convertidos em Tabelas e Gráficos que possibilitaram suas respectivas projeções e análises.

Por fim, a análise dos dados obtidos se desenvolveu a partir de correlações entre o que as referências bibliográficas levantadas na revisão de literatura apresentaram, com o que se 
obteve, enquanto informações que representam o cotidiano de gestão de pessoas nos hotéis que contribuíram à realização desta pesquisa.

\section{6 - Período de realização da pesquisa}

Para o desenvolvimento desta pesquisa, o levantamento bibliográfico para a finalidade de se realizar uma revisão de literatura focada nas associações entre Gestão de Pessoas e Hotelaria, ocorreu no período de janeiro a fevereiro de 2009. A partir da obtenção de tais referências, foi possível analisar e transcrever contribuições advindas de outros pesquisadores, e estruturar o conteúdo do "Referencial Teórico" desta pesquisa, no período de março a junho de 2009.

Quanto às investigações sobre as práticas cotidianas da administração de recursos humanos em hotéis juizforanos, essas se limitaram à realização de coleta de dados primários, com base em aplicação de questionários fechados aos gerentes gerais representantes do grupo analisado nesta pesquisa. Tal etapa se estendeu do dia 18 de abril de 2009 a 11 de junho de 2009.

Entre os dias 11 a 14 de junho de 2009, os dados foram tabulados, de modo a gerar quadros e tabelas que orientaram a análise e discussão comparativa ao conteúdo levantado pela bibliografia consultada ao desenvolvimento da breve revisão de literatura sobre gestão de pessoas em organizações hoteleiras.

A redação do elemento “considerações finais” desta pesquisa se realizou no dia 15 de junho de 2009, determinando a conclusão da elaboração deste estudo. 


\section{V - APRESENTAÇÃO E ANÁLISE DOS DADOS}

Uma vez que o objetivo principal desta pesquisa consistiu em descrever quais são as atividades de Gestão de Pessoas realizadas para promoverem o diferencial estratégico da organização hoteleira, foi realizada coleta de dados primários através da aplicação de um questionário (instrumento deste trabalho), composto por dez perguntas fechadas e aplicado ao grupo composto por onze gerentes gerais de hotéis juizforanos.

Os dados obtidos caracterizam as respostas prestadas por aqueles gerentes ao instrumento que foi aplicado. Tais dados foram agrupados em uma planilha, e processados através da ferramenta Microsoft Excel. Esse processamento consistiu na execução da tabulação daqueles dados, possibilitando a elaboração de gráficos e tabelas. Para tanto, os conjuntos de cada uma das dez perguntas, junto às suas respectivas alternativas e freqüências de respostas apontadas pelos onze gerentes gerais que atuam no setor hoteleiro de Juiz de Fora, estão devidamente representados nas referidas tabelas e gráficos.

Este capítulo tem por objetivo apresentar os dados obtidos, bem como correlacionar os propósitos de cada uma das questões direcionadas aos gerentes gerais de hotéis que concordaram com a realização deste estudo, ao responderem ao questionário - instrumento elaborado neste trabalho. Portanto, a apresentação dos dados, em tabelas e gráficos, possibilitou a descrição e análise dos mesmos.

Somente a partir da análise dos elementos observados (dados obtidos pelas respostas ao instrumento, possíveis alternativas, freqüências de respostas, tabelas e gráficos representando essas variáveis) foi possível discutir sobre como realmente se aplicam as atividades da área de Gestão de Pessoas no cotidiano dos hotéis pesquisados, segundo as perspectivas dos gerentes.

Além disso, vale ressaltar que a realização desta pesquisa se baseou na adoção dos seguintes objetivos específicos: identificar as contribuições estratégicas da Gestão de Pessoas para a prestação dos serviços de hospedagem; analisar a importância do planejamento da Gestão de Pessoas; e comparar as principais práticas vigentes com as propostas e conteúdos pesquisados na literatura.

Assim sendo, à luz das análises dos dados, correlacionadas a investigação acerca dos mencionados objetivos específicos, obteve-se as observações e argumentações que culminaram nas considerações finais deste estudo. 


\section{1 - Análise descritiva dos dados}

De acordo com a realização dos levantamentos de referências bibliográficas, e com a estrutura desenvolvida no Referencial Teórico desta pesquisa, preocupou-se em questionar aos gerentes sobre a classificação dos serviços de hospedagem na organização que gerenciam, acreditando que essa seria uma questão preparatória para a reflexão da administração hoteleira, inicialmente geral para, a partir desse “despertar”, orientar as questões seguintes para o foco da pesquisa: a área de Gestão de Pessoas nos hotéis.

As respostas em relação à classificação dos hotéis pesquisados são apresentadas na tabela abaixo.

TABELA 01: Qual é a classificação do seu hotel, na perspectiva dos serviços de hospedagem que oferece?

\begin{tabular}{l|r|r}
\hline & Frequência & \multicolumn{1}{c}{$\%$} \\
\hline 1 estrela; & 0 & 0,00 \\
\hline 2 estrelas; & 0 & 0,00 \\
\hline 3 estrelas; & 0 & 0,00 \\
\hline 4 estrelas; & 0 & 0,00 \\
\hline 5 estrelas; & 0 & 0,00 \\
\hline Não há definição quanto à classificação desse hotel; & 11 & 100,00 \\
\hline Não sei. & 0 & 0,00 \\
\hline TOTAL: & $\mathbf{1 1}$ & $\mathbf{1 0 0 \%}$ \\
\hline
\end{tabular}

FONTE: Dados da pesquisa

Observa-se, nessa questão, a unanimidade que, segundo os gerentes gerais, todos os hotéis pesquisados não recebem classificação aos serviços de hospedagem que oferecem, conforme se observou na revisão de literatura sobre Gestão Hoteleira (conteúdo abordado no Capítulo 1), especialmente no que tange às explanações dos autores Castelli (2001), Petrocchi (2002), Acerenza (2002), Hayes e Ninemeier (2005).

É válido ressaltar que, durante a realização da pesquisa de campo, todos os gerentes que colaboraram para este estudo, ao entregarem o questionário respondido, argumentavam que os hotéis de Juiz de Fora não recebem esse tipo de classificação, atualmente atribuída pela Empresa Brasileira de Turismo (EMBRATUR).

Além da Tabela 01, é válido apresentar o Gráfico 01, referente aos dados obtidos na questão sobre a classificação dos serviços de hospedagem nos hotéis investigados: 


\section{GRÁFICO 01: Classificações dos serviços de hospedagem dos hotéis pesquisados}

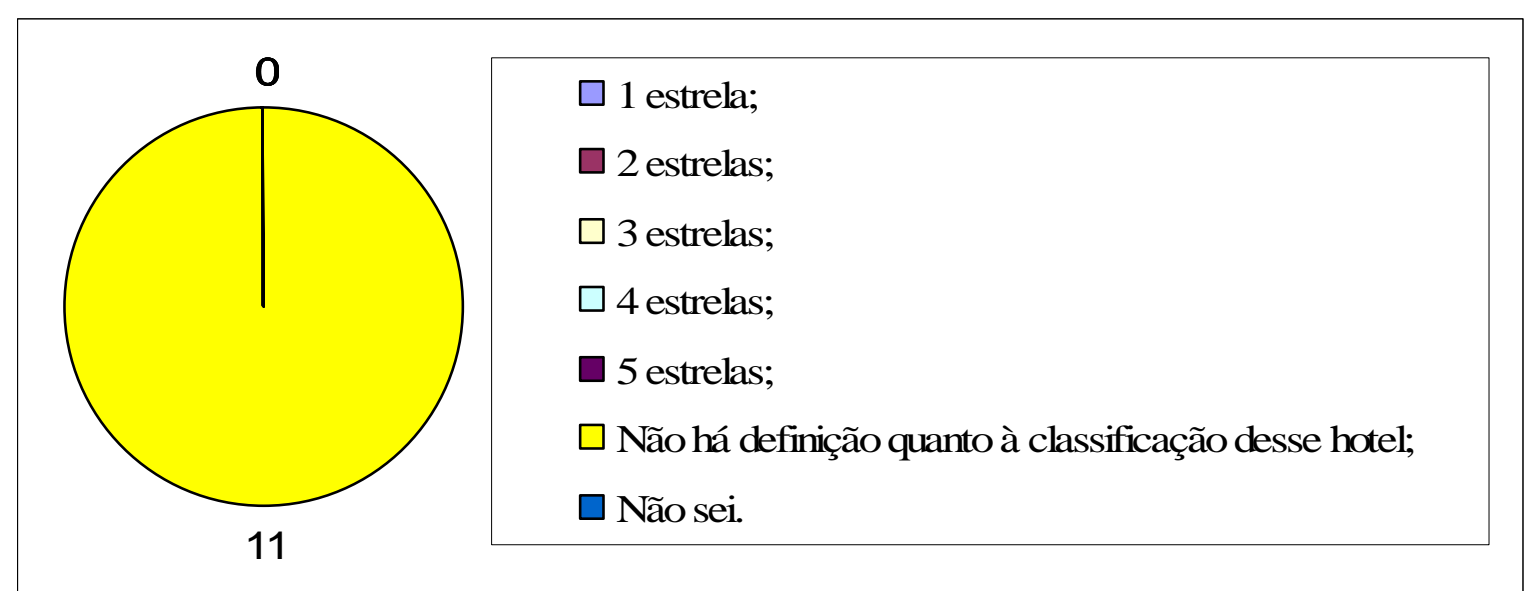

FONTE: Dados da pesquisa

O Gráfico 01 possibilita a visão mais evidente da unanimidade de respostas prestadas a essa primeira questão, conforme apresentada no instrumento aplicado para coleta de dados.

Ainda sob a intenção de introduzir ao foco da pesquisa, no momento de aplicação do questionário, e conforme se observa na Tabela 02, questionou-se aos gerentes gerais se existiam departamentos, ou setores, próprios para a área de Gestão de Pessoas no hotel onde trabalham, uma vez que, conforme observado em explanações de alguns autores (tais como CASTELLI, 2001; PETROCHI, 2002; HAYES E NINEMEIER, 2005), na etapa do desenvolvimento da revisão de literatura sobre Gestão Hoteleira, acredita-se que hotéis de pequeno porte - principalmente aqueles administrados por famílias proprietárias de tal tipo de empreendimento - geralmente possuem um número restrito de funcionários. Frente a essa possibilidade de se deparar com uma organização hoteleira que apresente um reduzido número de funcionários, é possível que neste tipo de hotel não sejam atribuídas, aos gerentes, tarefas devidamente orientadas para respectivas áreas administrativas, de modo que as práticas de gestão de pessoas podem, simplesmente, serem inseridas na aplicação de uma administração geral. Daí a relevância em se questionar se aqueles hotéis pesquisados possuíam, em suas respectivas estruturas organizacionais, departamento, ou setores, próprios para a execução exclusiva de operações pertinentes à gestão de pessoas. 
TABELA 02: Existe, no hotel gerenciado pelo(s) senhor(a), um departamento - ou setor - próprio para práticas da área de Administração de Recursos Humanos, ou Gestão de Pessoas?

\begin{tabular}{l|r|r}
\hline & Frequência & \multicolumn{1}{c}{$\%$} \\
\hline Sim; & 11 & 100,00 \\
\hline Não; & 0 & 0,00 \\
\hline Não sei. & 0 & 0,00 \\
\hline TOTAL: & $\mathbf{1 1}$ & $\mathbf{1 0 0 \%}$ \\
\hline
\end{tabular}

FONTE: Dados da pesquisa

O gráfico 02, correspondente ao questionamento quando à estruturação de um departamento/setor específico para a área de Gestão de Pessoas, é apresentado a seguir:

\section{GRÁFICO 02: Existe setor/departamento de RH no hotel?}

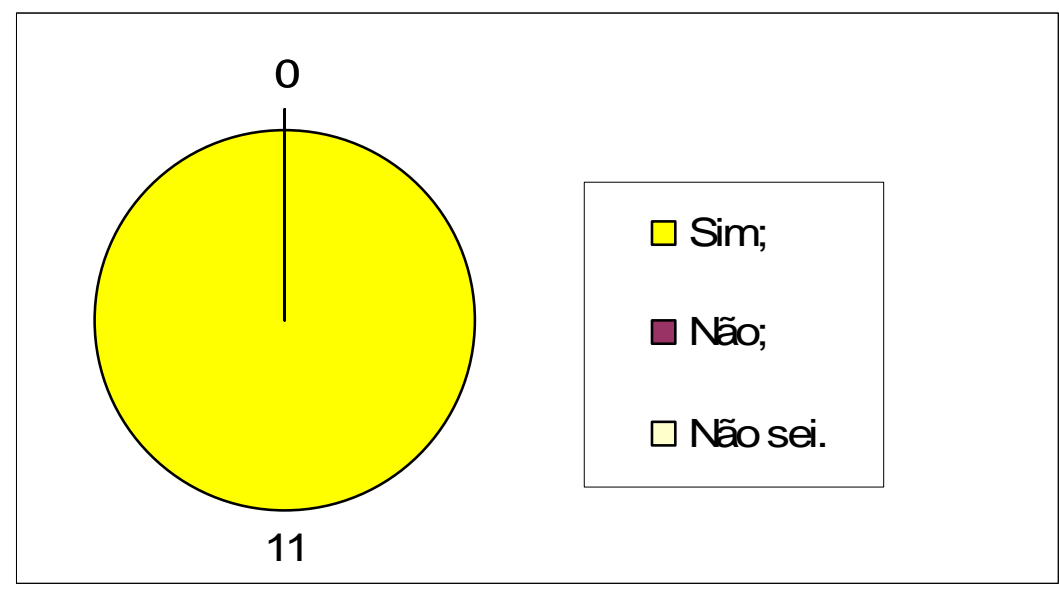

FONTE: Dados da pesquisa

Os dados obtidos nesta essa segunda questão, conforme se observa na Tabela 02, e no Gráfico 02, convergiram para mais uma “unanimidade” de respostas - desta vez, a afirmação de que os hotéis investigados possuem setor/departamento exclusivo para a área de Gestão de Pessoas. Deste modo, foi possível a conduzir para a aplicação da pergunta “2.1”, cujas freqüências de respostas são projetadas na Tabela 2.1, uma vez que todos aqueles gerentes afirmaram existir um setor/departamento próprio à área de RH nos hotéis em que atuam. 
TABELA 2.1: Se “sim", as atividades desse departamento - ou setor - se concentram em:

\begin{tabular}{l|r|r}
\hline & Frequência & \multicolumn{1}{c}{$\%$} \\
\hline $\begin{array}{l}\text { controle e fluxo documental para registros de } \\
\begin{array}{l}\text { Departamento Pessoal (folhas de pagamento, controle } \\
\text { de faltas e atestados médicos, admissão e rescisão de } \\
\text { contrato); }\end{array}\end{array}$ & 7 & 63,63 \\
\hline $\begin{array}{l}\text { procedimentos simples, com exclusividade em } \\
\text { recrutamento e seleção de pessoas; }\end{array}$ & 2 & 18,18 \\
\hline $\begin{array}{l}\text { processos elaborados, como descrição de cargos para } \\
\text { definição e ajustes salariais por categoria profissional, } \\
\text { determinação de planos de carreira e identificação de }\end{array}$ & & \\
$\begin{array}{l}\text { necessidades de treinamento e desenvolvimento } \\
\text { (T\&D); }\end{array}$ & 2 & 18,18 \\
\hline $\begin{array}{l}\text { programas estratégicos, como aplicação de pesquisas de } \\
\text { lima para diagnóstico organizacional, intervenções à } \\
\text { melhoria contínua, mapeamento e gestão de } \\
\text { competências, além de criação e implantação de }\end{array}$ & 0 & 0,00 \\
programas de qualidade de vida no trabalho. & $\mathbf{1 1}$ & $\mathbf{1 0 0 , 0 0}$ \\
\hline TOTAL: & & \\
\hline
\end{tabular}

FONTE: Dados da pesquisa

Uma vez que todos os hotéis pesquisados apresentam setor/departamento próprio para a área de Gestão de Pessoas, questionou-se qual seria o tipo de atividades concentradas naquele setor/departamento. Além das freqüências projetadas na Tabela 2.1, o Gráfico 2.1 também possibilita a visualização do índice de respostas referentes àquela concentração das atividades de Gestão de Pessoas nos hotéis pesquisados. 


\section{GRÁFICO 2.1: As atividades de RH no hotel se concentram em:}

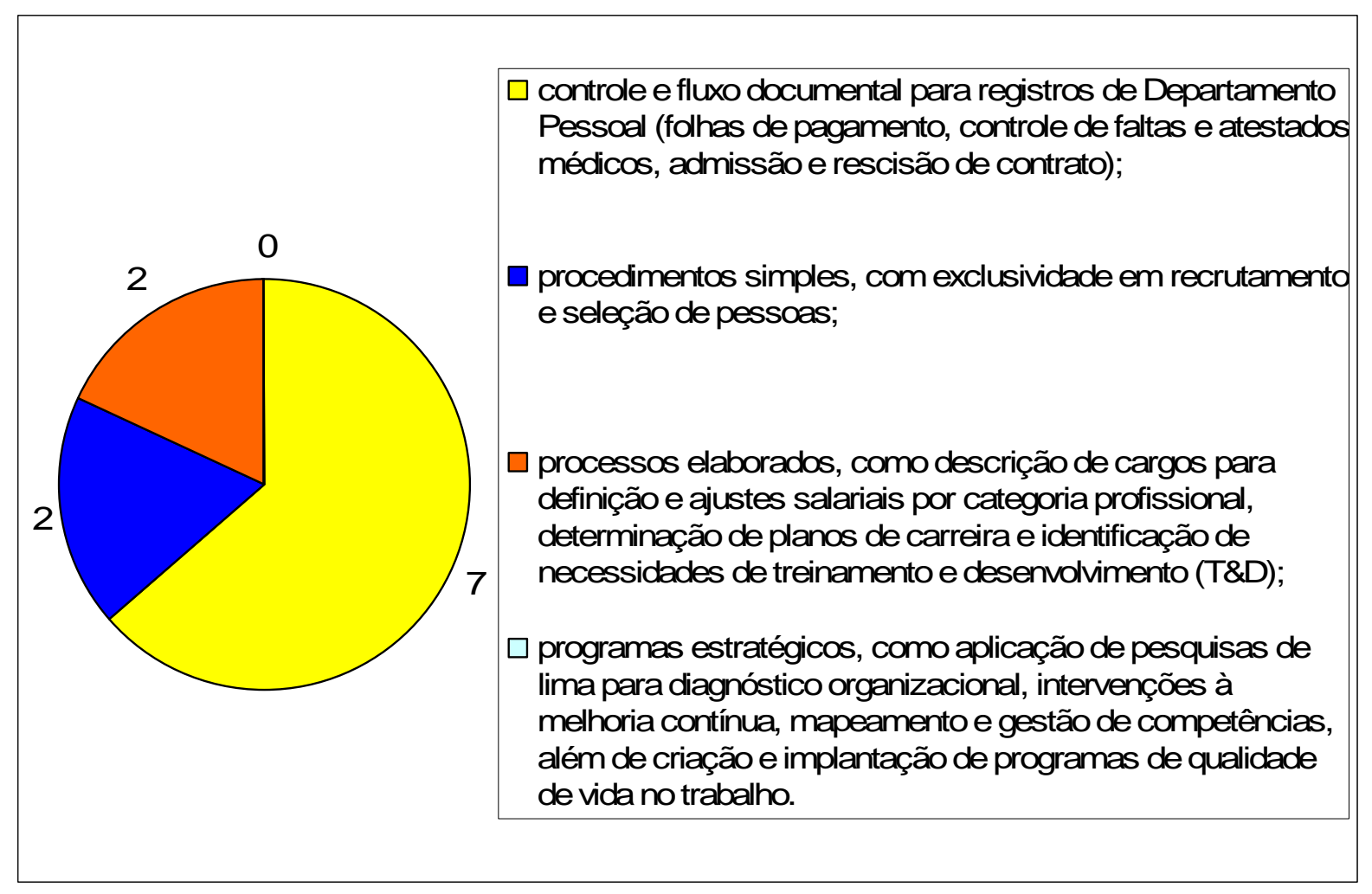

FONTE: Dados da pesquisa

Observa-se que no grupo dos onze gerentes participantes deste estudo, a maioria (sete) apontou que as atividades da Administração de Recursos Humanos, nos hotéis onde trabalham, se concentram no "controle e fluxo documental para registros de Departamento Pessoal”, enquanto dois daqueles gerentes apontaram para a assertiva de que as atividades de RH se concentram em "procedimentos simples, com exclusividade em recrutamento e seleção de pessoas", e outros dois gerentes sinalizaram para a alternativa de "processos elaborados, como a descrição de cargos para definição e ajustes salariais por categoria profissional, determinação de planos de carreira e identificação de necessidades de treinamento e desenvolvimento" de pessoal.

A Tabela 03 apresenta os dados sobre como se realizam os processos de recrutamento e seleção de pessoas para a composição do quadro de funcionários efetivos dos hotéis. 
TABELA 03: Geralmente, os processos de recrutamento e seleção no hotel onde o(a) senhor(a) trabalha, são:

\begin{tabular}{l|r|r}
\hline & Frequência & \multicolumn{1}{c}{$\%$} \\
\hline $\begin{array}{l}\text { desenvolvidos pelos próprios gerentes dos } \\
\text { departamentos - ou setores - solicitantes; }\end{array}$ & 5 & 45,45 \\
\hline $\begin{array}{l}\text { realizados pela própria equipe de RH - ou de Gestão de } \\
\text { Pessoas; }\end{array}$ & 6 & 54,55 \\
\hline $\begin{array}{l}\text { prestados por terceiros, a exemplo de consultorias, ou } \\
\text { por agências de empregos; }\end{array}$ & 0 & 0,00 \\
\hline não ocorrem processos seletivos nesse hotel. & 0 & 0,00 \\
\hline Não sei. & 0 & 0,00 \\
\hline TOTAL: & $\mathbf{1 1}$ & $\mathbf{1 0 0 , 0 0}$ \\
\hline
\end{tabular}

FONTE: Dados da pesquisa

Conforme apontado pelos autores Gil (2006) e Zavaglia (2006), os processos de recrutamento e seleção de pessoas podem ser realizados sob diferentes enfoques, através da adoção de diversos instrumentos e métodos, desde que sejam orientados à identificação de candidatos com perfis adequados ao exercício das funções, conforme objetivadas para o bom desempenho de uma organização. Ao se questionar como se aplica essa premissa no cotidiano dos hotéis pesquisados, dentre os gerentes de hotelaria que participaram desta pesquisa, $45,45 \%$ do grupo (o que corresponderia a cinco integrantes) revelou que os processos de recrutamento e seleção nos hotéis são “desenvolvidos pelos próprios gerentes - ou setores que solicitam” novas contratações de pessoas, enquanto 54,55\% (os outros seis participantes) afirmaram que aqueles tipos de processo são “realizados pela própria equipe de $\mathrm{RH}$ - ou Gestão de Pessoas” que integram a estrutura dos respectivos hotéis. 
GRÁFICO 03: Como ocorrem processos de recrutamento e seleção nos hotéis pesquisados

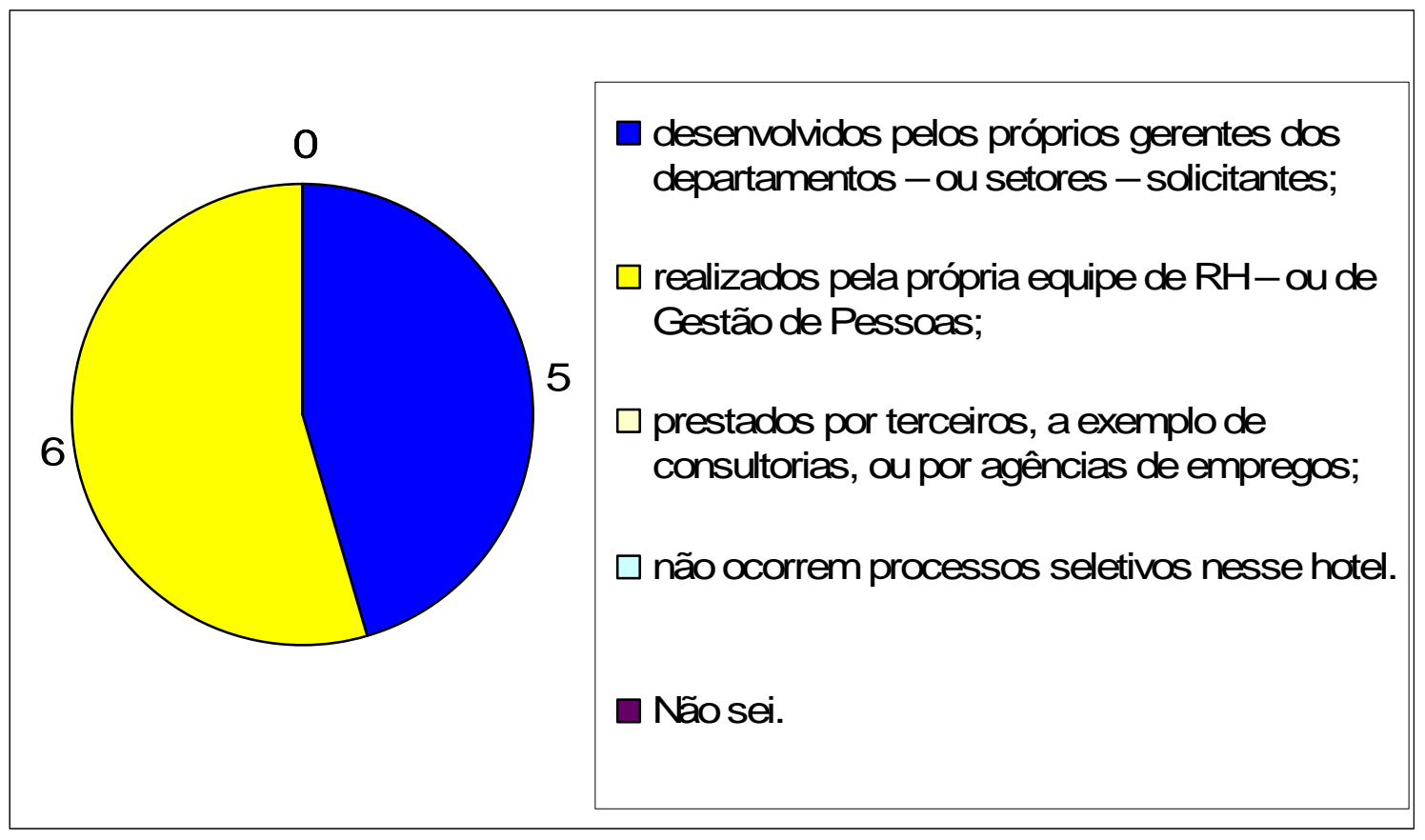

FONTE: Dados da pesquisa

É possível observar no Gráfico 03, que em nenhuma das organizações hoteleiras pesquisadas são realizados processos de recrutamento e seleção através de aquisição de serviços de consultoria ou agências de emprego - a exemplo do que Marras (2000), Gil (2006) e Zavaglia (2006) propõe, em comum, acerca dos possíveis métodos para a realização daqueles tipos de processos. Também é possível observar que em todos os onze hotéis investigados são realizados processos de recrutamento e seleção de pessoas, ou seja, é possível inferir que em tais organizações o quadro de funcionários não é considerado um elemento estático, indicando que ocorrem novas admissões e/ou contratações de funcionários.

A Tabela 04 apresenta os dados referentes à implantação de programas para o desenvolvimento de planos de carreira aos hoteliers que trabalham nos hotéis estudados.

TABELA 04: Existem oportunidades para os hoteliers de sua organização desenvolverem plano de carreira?

\begin{tabular}{l|r|c}
\hline & Frequência & \multicolumn{1}{c}{$\%$} \\
\hline Não; & 4 & 36,36 \\
\hline $\begin{array}{l}\text { Sim, periodicamente são realizados recrutamentos } \\
\text { internos; }\end{array}$ & 0 & 0,00 \\
\hline Sim, de acordo com desempenhos que se destacam; & 6 & 54,55 \\
\hline
\end{tabular}




\begin{tabular}{l|r|r}
$\begin{array}{l}\text { Sim, de acordo com planejamentos do departamento - } \\
\text { ou setor - de RH - ou Gestão de Pessoas; }\end{array}$ & 1 & 9,09 \\
\hline Não sei. & 0 & 0,00 \\
\hline TOTAL: & $\mathbf{1 1}$ & $\mathbf{1 0 0 , 0 0}$ \\
\hline
\end{tabular}

FONTE: Dados da pesquisa

Gil (2006) argumenta que a adoção de planos de carreira pode corresponder a uma significativa alternativa capaz de comprometer os funcionários para os melhores resultados de seus desempenhos, assim como a autora Ross (2002) afirma que promover a expectativa dos funcionários representa uma das possibilidades de se promover a motivação para o trabalho.

Frente à estimativa de que correlacionar a oportunidade de desenvolvimento de planos de carreiras à motivação dos funcionários, observou-se, na pesquisa de campo, que a maioria dos participantes (seis gerentes gerais; 54,55\% do grupo estudado) afirmaram que “sim”, há oportunidades para desenvolvimento de planos de carreiras nos hotéis que gerenciam, sendo que tal tipo de oportunidade é oferecida "de acordo com desempenhos que se destacam". Quatro gerentes (36,36\% do grupo) apontaram que "não” há oportunidades para desenvolvimento de planos de carreiras nas organizações hoteleiras, e somente um gerente $(9,09 \%)$ apontou que no respectivo hotel em que trabalha, são oferecidas oportunidades para plano de carreiras, coerentes aos "planejamentos do departamento - ou setor - de RH, ou Gestão de Pessoas” daquela organização.

\section{GRÁFICO 04: Há oportunidades de planos de carreias nos hotéis pesquisados?}

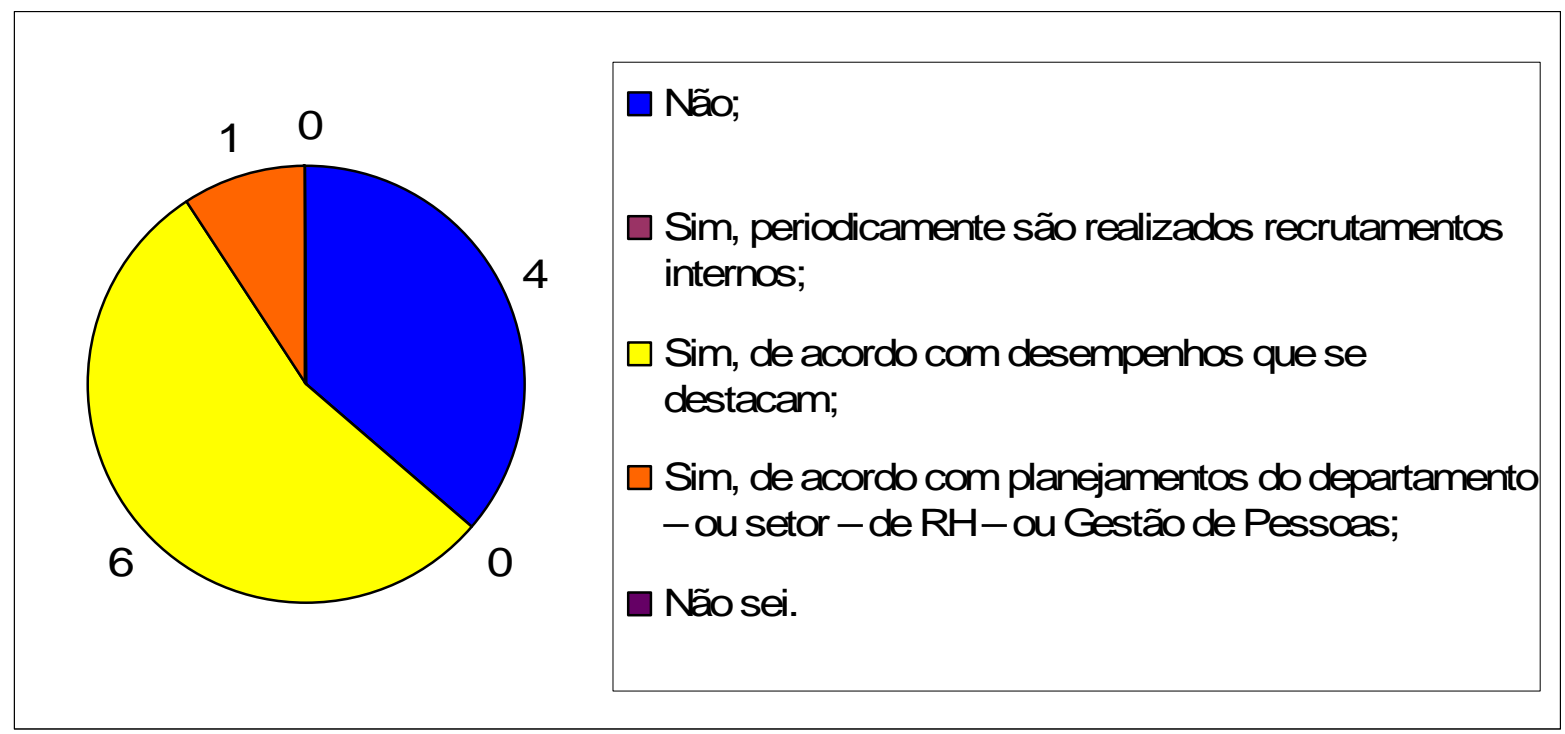

FONTE: Dados da pesquisa 
Através do Gráfico 04 observa-se que a maioria dos hotéis pesquisados oferece oportunidades para o desenvolvimento de planos de carreiras aos hoteliers que se destacam ao realizarem suas tarefas à prestação dos serviços de hospedagem.

Acerca da aplicação de programas de treinamento e desenvolvimento, questionou-se aos gerentes gerais de hotéis se são oferecidos tais tipos de programas nas respectivas organizações hoteleiras em que trabalham e, em caso afirmativo, como são realizados aqueles programas.

TABELA 05: Os hoteliers dessa organização recebem treinamentos?

\begin{tabular}{l|r|r}
\hline & Frequência & \multicolumn{1}{c}{$\%$} \\
\hline Não; & 2 & 18,18 \\
\hline Sim, somente quando são contratados; & 6 & 54,55 \\
\hline Sim, quando são contratados e a cada 6 meses; & 1 & 9,09 \\
\hline Sim, após consolidada sua admissão, e a cada 6 meses; & 0 & 0,00 \\
\hline Sim, uma vez ao ano; & 2 & 18,18 \\
\hline Não sei. & 0 & 0,00 \\
\hline TOTAL: & $\mathbf{1 1}$ & $\mathbf{1 0 0 , 0 0}$ \\
\hline
\end{tabular}

FONTE: Dados da pesquisa

É possível observar na Tabela 05 e no Gráfico 05 que a maioria dos gerentes de hotéis que participaram da pesquisa (seis integrantes, correspondendo a 54,55\% do grupo) afirmou que, nas organizações onde trabalham, os funcionários recebem treinamentos somente quando são contratados. Dois gerentes responderam que os hoteliers "não” recebem treinamentos, e outros dois apontaram que treinamentos são oferecidos, aos funcionários dos respectivos hotéis que gerenciam, somente “uma vez ao ano”. Apenas um gerente indicou que o hotel onde trabalha oferece treinamentos aos funcionários quando esses são contratados, e em intervalos de seis meses. É válido ressaltar, na análise desse item, que diversos autores (MILIONI, 2006; FELIPPE, 2006; BORGES-ANDRADE, 2006) argumentam que treinar os funcionários corresponde a um investimento da organização, uma vez que capacitá-los pode se revelar como condição determinante para a melhoria na prestação dos serviços.

No caso das organizações hoteleiras, estima-se que os treinamentos aplicados aos hoteliers possam resultar na melhoria da prestação dos serviços de hospedagem, implicando não somente no prazer do hóspede atendido, como também na geração de vantagens 
competitivas no mercado globalizado que, segundo Hayes e Ninemeier (2005), representam o macroambiente de uma organização hoteleira, no qual os hotéis buscam superar suas concorrência para a atratividade de potenciais clientes (no caso, os turistas que assumem a condição de hóspedes).

\section{GRÁFICO 05: Os hoteliers recebem treinamentos?}

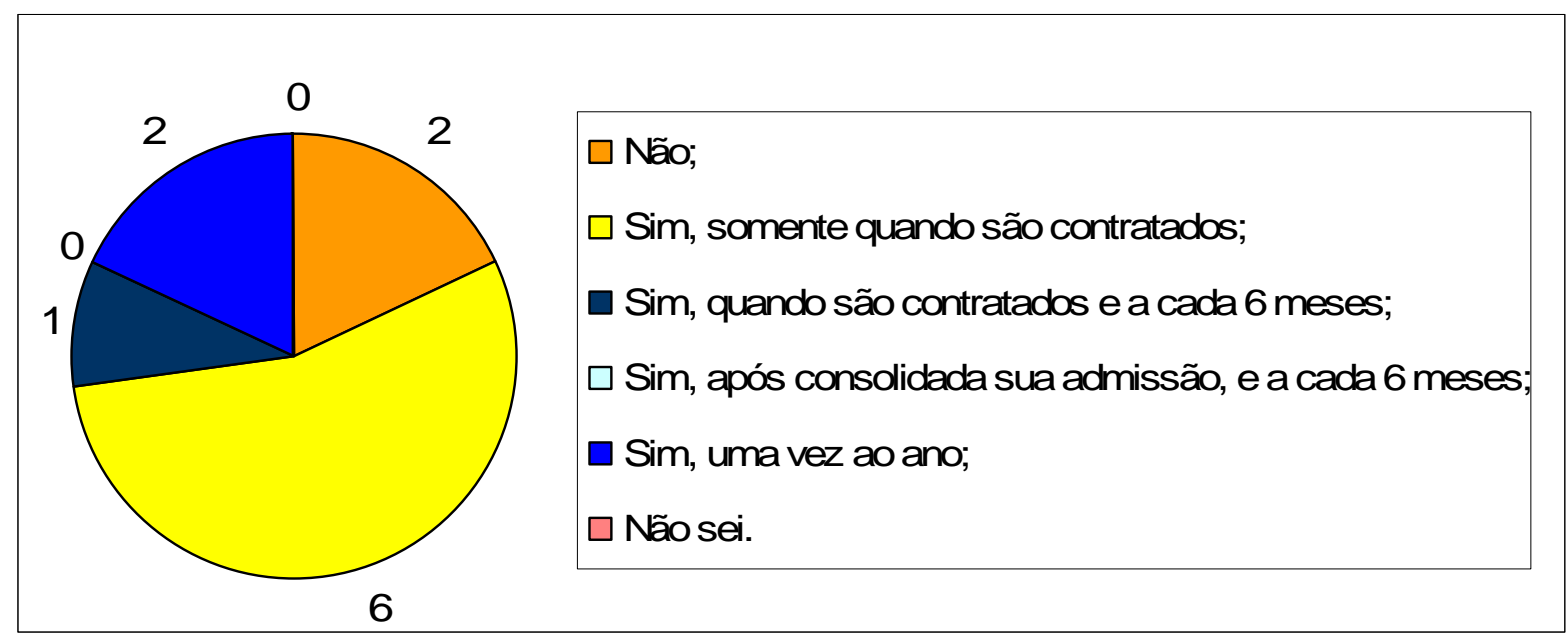

FONTE: Dados da pesquisa

Comparando os dados apresentados na Tabela 05 e no Gráfico 05, com os dados projetados na Tabela 06 e Gráfico 06, observa-se que, enquanto no item 05 do instrumento de pesquisa somente dois gerentes de hotéis responderam que as organizações que gerenciam não oferecem treinamentos aos seus funcionários, esse número parece ter aumentado no item 06, visto que a Tabela 06 e o Gráfico 06 projetam o índice de cinco gerentes $(45,45 \%$ dos investigados) terem respondido que "não há programas de T\&D” no hotel onde trabalham.

Pressupõe-se que três gerentes que integraram o grupo pesquisado tenham entendido que o treinamento oferecido aos funcionários no momento da contratação seja concebido como atividade complementar ao processo de recrutamento e seleção, uma vez que, de acordo com as respostas sinalizadas nos instrumentos, foram três gerentes que, no item 05 afirmaram que os funcionários só recebem treinamentos ao serem contratados, e no item 06 indicaram que não há programas de treinamento e desenvolvimento naquelas mesmas organizações hoteleiras.

Com base na projeção dos dados que compõem a Tabela 06, também é possível observar que outros cinco gerentes revelaram que programas de T\&D "são realizados no 
próprio espaço físico do hotel (treinamento on job), ministrados pelos próprios funcionários efetivos, cujos talentos se destacam”, e um gerente (o que corresponde a 9,09\% do grupo) indicou que os programas de T\&D são "realizados no próprio espaço físico do hotel (treinamento on job)” porém, “ministrados por especialistas contratados”. TABELA 06: Os programas de T\&D, direcionados aos profissionais desse hotel,
geralmente são:

\begin{tabular}{l|r|r}
\hline & Frequência & \multicolumn{1}{c}{$\%$} \\
\hline Não há programas de T\&D nesse hotel; & 5 & 45,45 \\
\hline $\begin{array}{l}\text { Realizados no próprio espaço físico do hotel } \\
\text { (treinamento on job), ministrados por especialistas } \\
\text { contratados; }\end{array}$ & 1 & 9,09 \\
\hline $\begin{array}{l}\text { Realizados no próprio espaço físico do hotel } \\
\text { (treinamento on job), ministrados pelos próprios } \\
\text { funcionários efetivos, cujos talentos se destacam; }\end{array}$ & 5 & 45,45 \\
\hline $\begin{array}{l}\text { Ministrados em estruturas próprias para esses } \\
\text { programas, como SENAC, conselhos de turismo e } \\
\text { hotelaria, ou sindicatos; }\end{array}$ & 0 & 0,00 \\
\hline Não sei. & $\mathbf{0}$ & 0,00 \\
\hline TOTAL: & $\mathbf{1 1}$ & $\mathbf{1 0 0 , 0 0}$ \\
\hline
\end{tabular}

FONTE: Dados da pesquisa

Acerca de como se realizam programas de T\&D nos próprios espaços físicos dos hotéis estudados (treinamento on job), e a partir do Gráfico 06, observa-se um "empate” na indicação das alternativas “ministrados pelos funcionários cujos talentos se destacam”, e “ministrados por especialistas contratados”. Essa constatação permite estimar que os gerentes de hotelaria ainda não confiam na contratação de instituições especializadas à execução de programas de treinamento e desenvolvimento. 
GRÁFICO 06: Nos hotéis pesquisados, os programas de T\&D são:

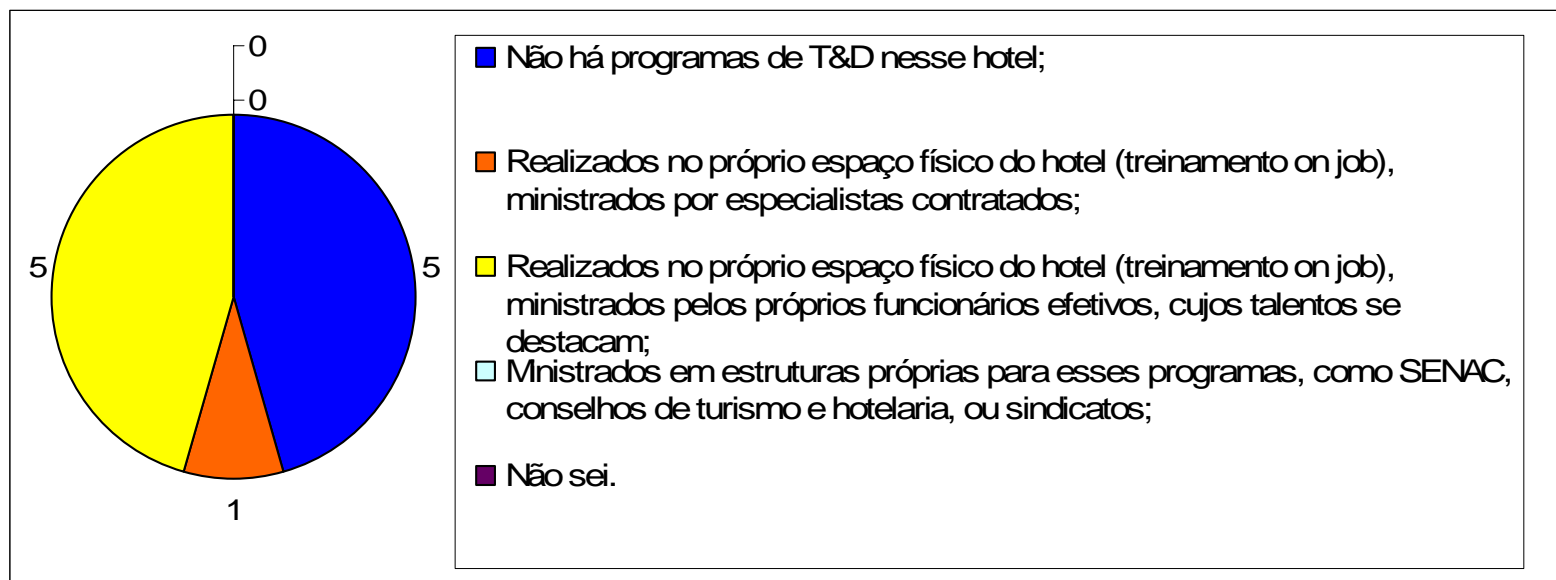

FONTE: Dados da pesquisa

O item 07, cujos dados são projetados nas Tabela 07 e no Gráfico 07, refere-se ao questionamento quanto à aplicação de avaliações de desempenho dos funcionários que compõem o quadro de efetivos nos hotéis.

TABELA 07: São aplicadas avaliações de desempenho nesse hotel?

\begin{tabular}{l|r|r}
\hline & Frequência & \multicolumn{1}{c}{$\%$} \\
\hline Não; & 7 & 63,64 \\
\hline Sim, a cada trimestre; & 1 & 9,09 \\
\hline Sim, a cada semestre; & 0 & 0,00 \\
\hline Sim, anualmente; & 3 & 27,27 \\
\hline Sim, somente quando se identifica a necessidade; & 0 & 0,00 \\
\hline Não sei. & 0 & 0,00 \\
\hline TOTAL: & $\mathbf{1 1}$ & $\mathbf{1 0 0 , 0 0}$ \\
\hline
\end{tabular}

FONTE: Dados da pesquisa

Do grupo estudado, sete gerentes (63,64\%) responderam que "não” são aplicadas avaliações de desempenho aos funcionários com quem trabalham. Três (27,27\%) apontaram que aquele tipo de avaliação é aplicada uma vez ao ano, e um (9,09\%) afirmou que são aplicadas avaliações de desempenho dos hoteliers a cada trimestre. 
Vale lembrar que Marras (2000) enfatiza que as avaliações de desempenho, ao serem aplicadas podem acarretar em mudanças internas - e, possivelmente, necessárias - num contexto organizacional. Com base na pesquisa de campo, não é possível afirmar que seja necessária, aos hotéis pesquisados, a aplicação de avaliações de desempenho com a finalidade de se aprimorar a performance dos hoteliers em Juiz de Fora, mas se mantém o questionamento acerca da concepção dos gerentes de hotéis quanto aquele tipo de avaliação. Será que acreditam na validade desse processo? Este pode ser um problema que possibilite a realização de novas pesquisas.

As projeções quanto às indicações das alternativas "Não"; “Sim, a cada trimestre”; e “Sim, anualmente” no que tange à aplicação de avaliações de desempenho dos funcionários dos onze hotéis pesquisados são apresentadas no Gráfico 07.

\section{GRÁFICO 07: São aplicadas avaliações de desempenho nos hotéis pesquisados?}

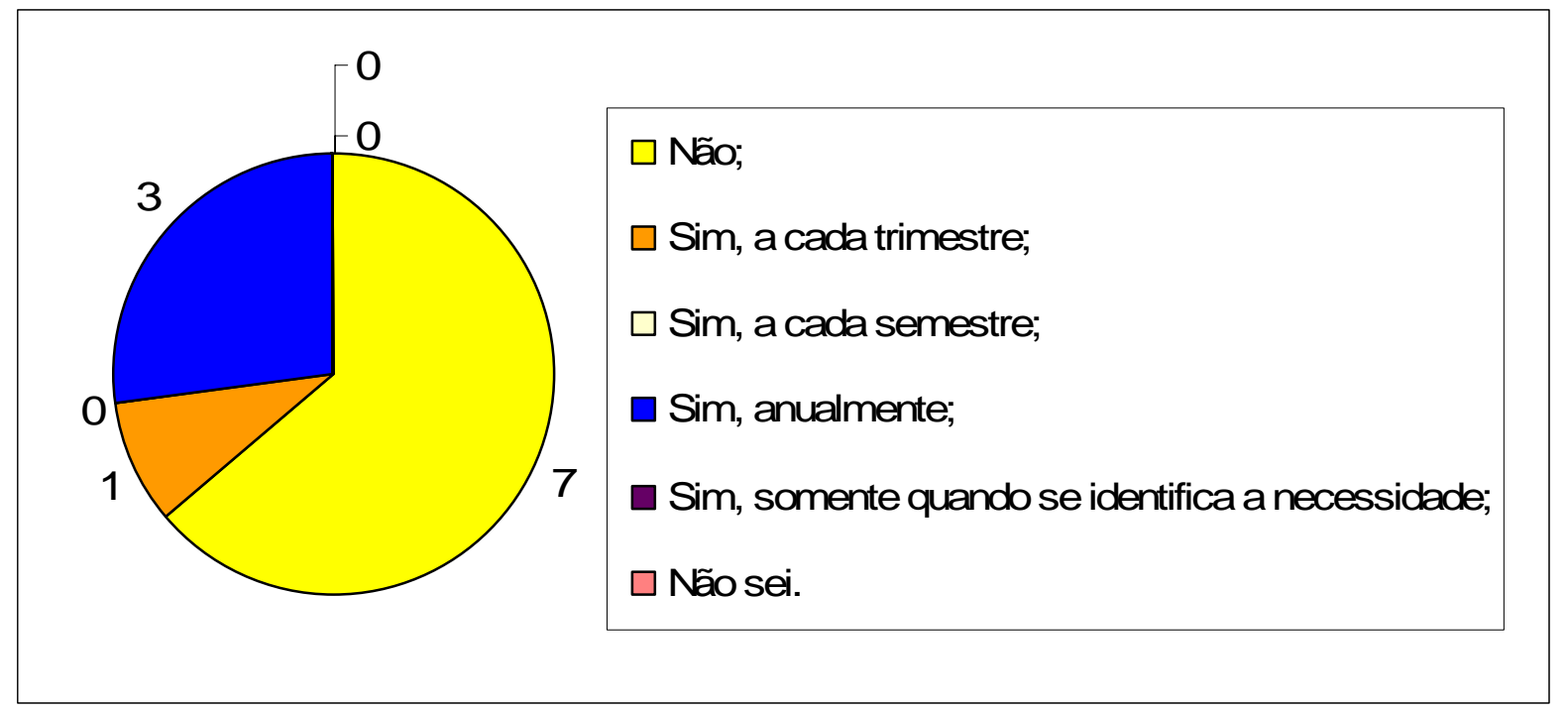

FONTE: Dados da pesquisa

Conforme abordado no Referencial Teórico, especificamente no Capítulo 3 - cujo conteúdo se concentrou na associação das operações de Gestão de Pessoas ao cotidiano operacional as organizações hoteleiras - evidenciou-se que a atividade de descrição de cargos orienta outros processos à “administração dos recursos humanos” nos hotéis. A Tabela 08 apresenta os dados obtidos frente ao questionamento sobre como aquela atividade. Cinco gerentes responderam que "não há nenhuma descrição de cargos devidamente formalizada” no hotel que gerenciam. Os outros seis componentes do grupo investigado afirmaram que 
“sim”, que as práticas de Gestão de Pessoas, nos hotéis onde trabalham, são orientadas de acordo com uma descrição de cargos já desenvolvida.

TABELA 08: As práticas de Gestão de Pessoas, no hotel pesquisado, são orientadas de acordo com uma descrição de cargos, já desenvolvida?

\begin{tabular}{l|r|r}
\hline & Frequência & \multicolumn{1}{c}{$\%$} \\
\hline $\begin{array}{l}\text { Não há nenhuma descrição de cargos devidamente } \\
\text { formalizada nesse hotel; }\end{array}$ & 5 & 45,45 \\
\hline Sim; & 6 & 54,55 \\
\hline Não sei. & 0 & 0,00 \\
\hline TOTAL: & $\mathbf{1 1}$ & $\mathbf{1 0 0 , 0 0}$ \\
\hline
\end{tabular}

FONTE: Dados da pesquisa

Observa-se no Gráfico 08 que 45,45\% do grupo estudado revelou que não há descrição de cargos devidamente formalizada nos hotéis, ao passo que 54,55\% daquele grupo revelou que os hotéis adotam, sim, a aplicação da descrição de cargos para orientar outras atividades pertinentes à Gestão de Pessoas.

GRÁFICO 08: Há descrição de cargos nos hotéis pesquisados?

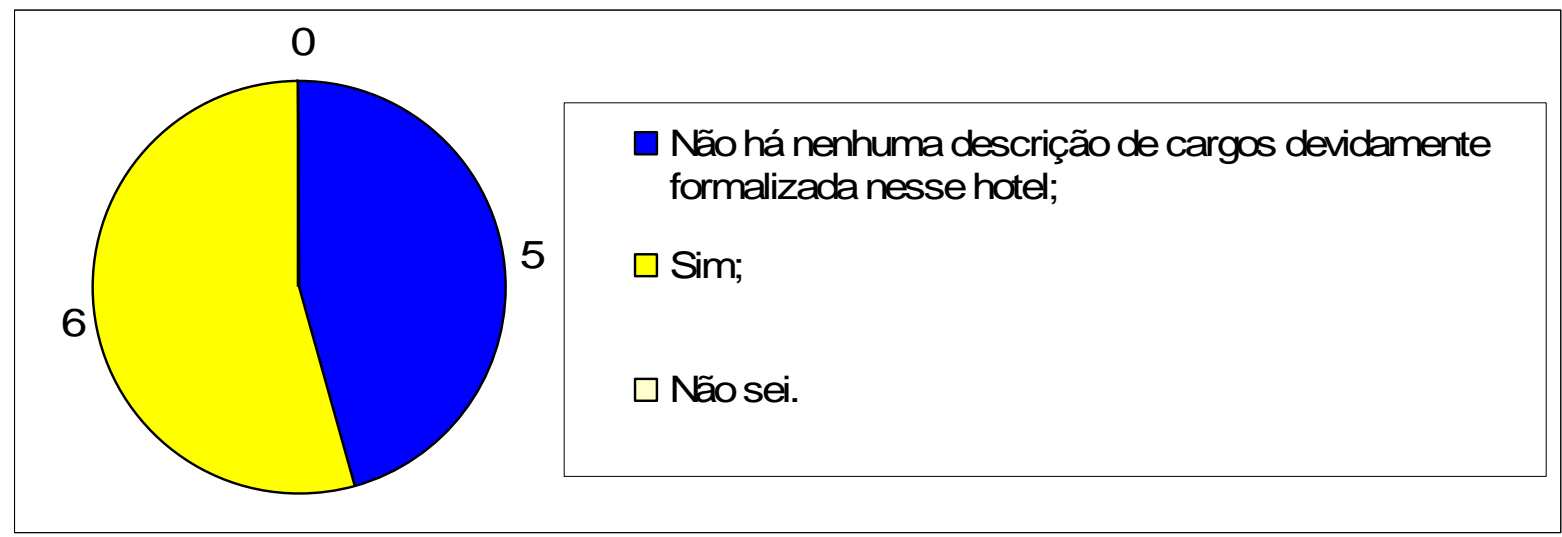

FONTE: Dados da pesquisa

Uma vez que se objetiva identificar as contribuições da Gestão de Pessoas ao bom desempenho de uma organização hoteleira, também se considerou válido questionar aos gerentes gerais de hotéis se existe a preocupação com a qualidade na prestação dos serviços de hospedagem, enquanto elemento norteador à Gestão Hoteleira. 
Nessa perspectiva, conforme os dados projetados na Tabela 09, a grande maioria dos gerentes que participaram desta pesquisa (nove, correspondendo ao percentual de 81,82\%) afirmaram que "sim, são aplicadas pesquisas de satisfação e de opinião dos hóspedes atendidos", um daqueles gerentes apontou que "são aplicadas pesquisas de motivação dos hoteliers", revelando, assim, a preocupação com o comprometimento dos funcionários e, possivelmente, considerando essa variável um fator determinante para a excelência na prestação dos serviços de hospedagem do respectivo hotel que gerencia. Entretanto, também houve um gerente que indicou a "não” adoção de ferramentas para se mensurar a qualidade dos serviços oferecidos pelo hotel onde trabalha.

TABELA 09: Existem ferramentas para a mensuração da qualidade na prestação de serviços oferecidos nesse hotel?

\begin{tabular}{l|r|r}
\hline & Frequência & \multicolumn{1}{c}{$\%$} \\
\hline $\begin{array}{l}\text { Sim, são aplicadas pesquisas de satisfação/opinião dos } \\
\text { hóspedes atendidos; }\end{array}$ & 9 & 81,82 \\
\hline $\begin{array}{l}\text { Sim, são aplicadas pesquisas de motivação dos } \\
\text { hoteliers; }\end{array}$ & 1 & 9,09 \\
\hline $\begin{array}{l}\text { Sim, através da observação direta e avaliação dos } \\
\text { serviços prestados; }\end{array}$ & 0 & 0,00 \\
\hline Sim, através de outros meios; & 0 & 0,00 \\
\hline Não; & 1 & 9,09 \\
\hline Não sei. & 0 & 0,00 \\
\hline TOTAL: & $\mathbf{1 1}$ & $\mathbf{1 0 0 , 0 0}$ \\
\hline
\end{tabular}

FONTE: Dados da pesquisa

Evidencia-se no Gráfico 09 a primazia pela aplicação de pesquisas de satisfação e de opinião dos hóspedes como elemento comumente adotado pela Gestão Hoteleira no grupo pesquisado. Esse fato pode promover a formulação de novas questões acerca da preocupação gerencial sobre a qualidade de vida no trabalho, bem como a motivação dos funcionários dos hotéis, uma vez que, priorizando o foco apenas sobre a satisfação de hóspedes atendidos, os gerentes de hotéis não estariam abdicando esforços para mensurar e promover o maior comprometimento e motivação dos hoteliers. As questões que se concentrem nesse enfoque também podem orientar o desenvolvimento de novos estudos sobre a gestão de pessoas em hotelaria. 
GRÁFICO 09: A qualidade dos serviços de hospedagem é mensurada?

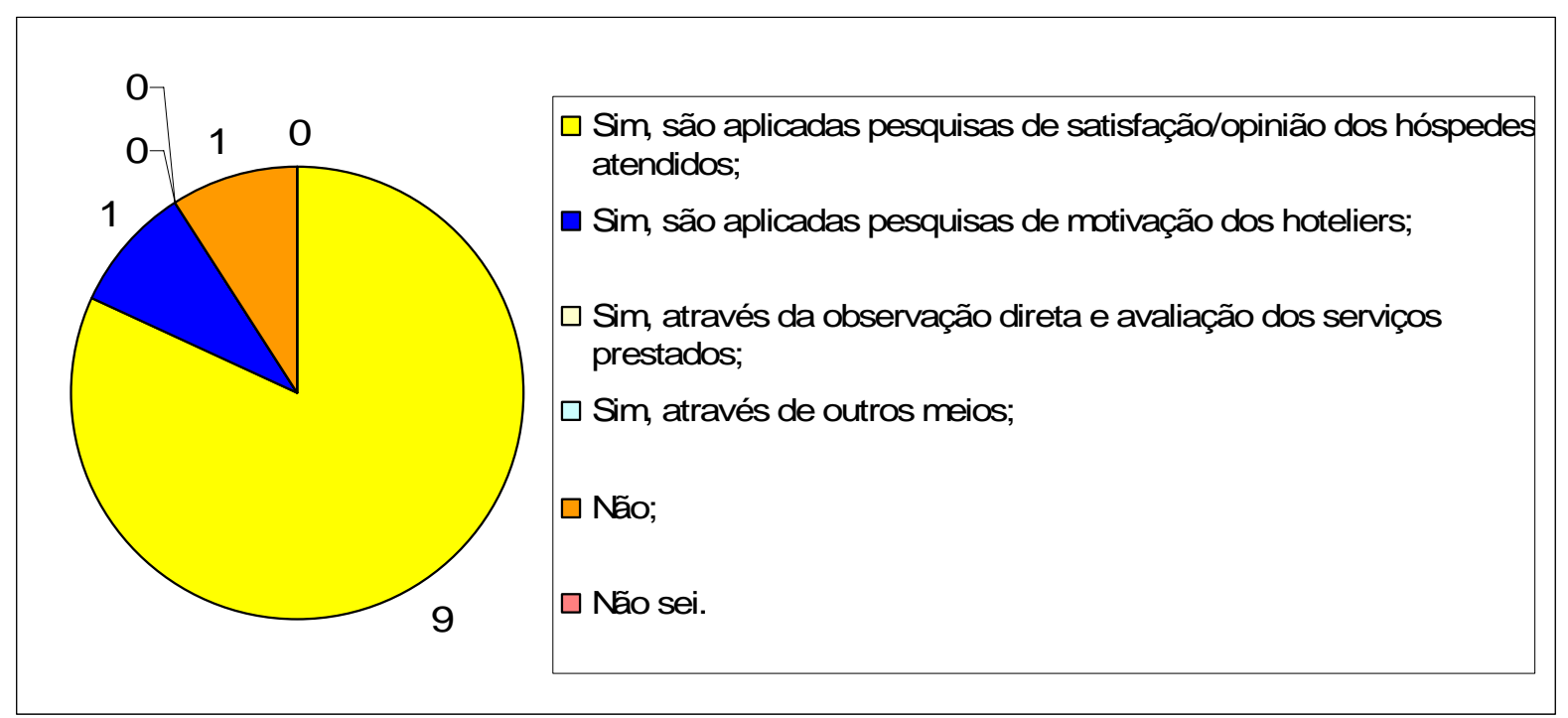

FONTE: Dados da pesquisa

Por fim, ressaltando que o instrumento deste estudo fora aplicado aos gerentes gerais de hotelaria, e não diretamente aos profissionais da área de Gestão de Pessoas, nos onze hotéis pesquisados, considerou-se extremamente importante questionar aqueles gerentes sobre como percebem a referida área organizacional para toda a estrutura de um empreendimento hoteleiro.

Assim sendo, a décima - e última - questão do instrumento de coleta de dados, teve por foco conhecer a perspectiva dos gerentes gerais dos hotéis pesquisados. Desse grupo, sete integrantes perceberam que "a área de Gestão de Pessoas, nos respectivos hotéis em que trabalham, pode colaborar mais para um melhor desempenho organizacional”; três gerentes responderam que "a gestão de pessoas assume caráter estratégico ao colaborar para o sucesso dos hotéis”; e apenas um não soube opinar acerca da contribuição da área de Gestão de Pessoas para empreendimentos de hotelaria.

TABELA 10: Na perspectiva dos gerentes gerais dos hotéis:

\begin{tabular}{l|r|r}
\hline & Frequência & \multicolumn{1}{c}{$\%$} \\
\hline $\begin{array}{l}\text { A gestão de pessoas assume caráter estratégico ao } \\
\text { colaborar para o sucesso do hotel; }\end{array}$ & 3 & 27,27 \\
\hline $\begin{array}{l}\text { A área de Gestão de Pessoas, nesse hotel, pode } \\
\text { colaborar mais para o seu bom desempenho } \\
\text { organizacional; }\end{array}$ & 7 & 63,64 \\
\hline
\end{tabular}




\begin{tabular}{l|r|r}
$\begin{array}{l}\text { Existem outras áreas administrativas mais importantes } \\
\text { do que a Gestão de Pessoas; }\end{array}$ & 0 & 0,00 \\
\hline $\begin{array}{l}\text { A Gestão de Pessoas é indiferente para a determinação } \\
\text { de diferenciais estratégicos do hotel sobre seu mercado; }\end{array}$ & 0 & 0,00 \\
\hline $\begin{array}{l}\text { Não sei opinar sobre a Gestão de Pessoas no hotel onde } \\
\text { trabalho. }\end{array}$ & 1 & 9,09 \\
\hline TOTAL: & $\mathbf{1 1}$ & $\mathbf{1 0 0 , 0 0}$ \\
\hline
\end{tabular}

FONTE: Dados da pesquisa

O Gráfico 10 apresenta a projeção quanto à maioria dos colaboradores da pesquisa terem apontado que a área de Gestão de Pessoas ainda pode contribuir mais para o melhor desempenho organizacional dos respectivos hotéis onde trabalham.

GRÁFICO 10: Nas perspectivas dos gerentes de hotéis que responderam ao questionário:

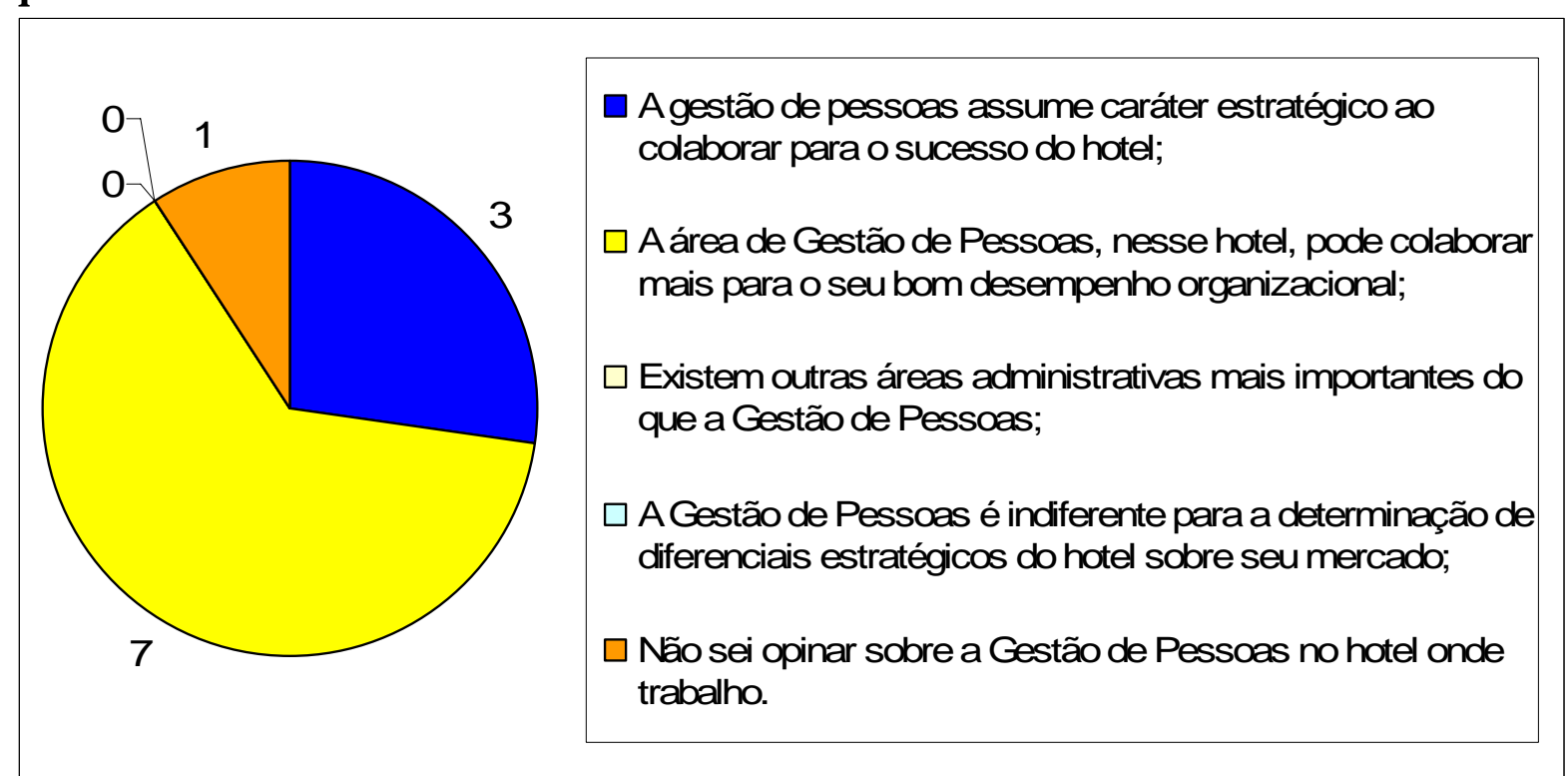

FONTE: Dados da pesquisa

Estima-se, portanto, que os profissionais de Gestão de Pessoas, ainda que inseridos nas organizações hoteleiras, podem refletir melhor sobre como essa área apresenta potenciais contribuições ao sucesso de um empreendimento hoteleiro, de modo a evidenciar mais a significância em aprimorar, valorizar e empregar o capital humano nos hotéis. 


\section{CONSIDERAÇÕES FINAIS}

A presente monografia teve como intenção descrever quais são as atividades de Gestão de Pessoas realizadas para promoverem o diferencial estratégico da organização hoteleira. Para tanto, o desenvolvimento deste trabalho se concentrou em analisar as práticas de gestão de pessoas que contribuem com o aumento de competitividade ou eficiência de uma organização hoteleira no mercado do Turismo em Juiz de Fora.

A indústria do Turismo revela diversas possibilidades para a criação e desenvolvimento de negócios. Entretanto, o setor hoteleiro representa um dos principais subsistemas do Turismo, especialmente por promover a interação entre turistas e os locais de atração turística, ao oferecer condições para aquele se manter no local visitado, independente da finalidade de sua experiência de contato com uma cultura diferente da sua original (seja para lazer, ou negócios).

Com isso, são inúmeras as publicações de trabalhos científicos sobre Gestão Hoteleira. Esta pesquisa, em especial, surgiu do interesse em se investigar as contribuições da Gestão de Pessoas àquele setor que representa um dos principais subsistemas do Turismo e, embora sua realização tenha se baseado no levantamento de referências bibliográficas, é válido apontar que foram poucas referências obtidas que se concentrassem, especialmente, na associação entre os dois temas aqui tratados (a Gestão Hoteleira e a Gestão de Pessoas), o que possibilita afirmar que esse se revela um campo próspero para a realização de novos estudos, principalmente novas publicações que forneçam condições ao desenvolvimento de novas pesquisas e aprimoramento do conhecimento sobre a valorização do capital humano nas organizações hoteleiras.

Há que se ressaltar que o hóspede, enquanto turista, experimentará contatos com a cultura que objetiva conhecer em sua experiência de Turismo. Esses tipos de contatos também são vividos pelo turista através de suas interações com os funcionários do hotel, ao adquirir serviços de hospedagem. Assim, refletir sobre a qualificação, formação pessoal e profissional, motivação para o trabalho e conhecimentos sobre a própria cultura local, por parte dos hoteliers, correspondem a significativas variáveis que devem ser trabalhadas pelos profissionais de gestão de pessoas que atuam no setor hoteleiro. Uma das principais expectativas desta pesquisa se concentra na colaboração àqueles profissionais, preocupados com o fator “capital humano” dos hotéis, quanto à aquisição de novos conhecimentos ou, simplesmente, despertar para novas reflexões, pois ainda há muito que se empreender para a 
consolidação da área de Gestão de Pessoas, enquanto fonte de significativa contribuição ao bom desempenho de uma organização hoteleira. Isso ficou evidenciado na realização da pesquisa de campo, quando os gerentes gerais de hotéis, participantes deste estudo, afirmaram que percebem aquela referida área organizacional como capaz de melhor colaborar para o bom desempenho organizacional de um hotel, enquanto resultado do comprometimento dos funcionários que atuam em tal tipo de empreendimento. Essa concepção, conforme observada na realização da breve revisão de literatura inserida neste trabalho, é fortemente difundida pelos teóricos da Gestão de Pessoas, enquanto área de conhecimento organizacional.

Foi possível identificar que os gerentes gerais de hotelaria (representantes das intenções e expectativas dos proprietários e investidores de um empreendimento hoteleiro, responsáveis por configurar tais expectativas em planos de ações realizados pelos funcionários do hotel) ainda não percebem a plenitude da Gestão de Pessoas como área organizacional determinante para a aquisição de diferenciais estratégicos e vantagens competitivas a uma organização hoteleira, conforme muitos teóricos defendem em suas argumentações. Isso ficou constatado no fato de muitos dos processos, cujos planejamentos e execuções cabem aos profissionais de gestão de pessoas, terem sido apontados como não sendo realizados em sua totalidade - principalmente no que tange à aplicação de avaliações de desempenho, conhecimento das possibilidades de contratação de instituições especializadas para a aplicação de programas de treinamento e desenvolvimento e, ainda, a efetiva adoção de critérios para descrição e análise de cargos. Com base nessas constatações, novas pesquisas podem ser realizadas sobre o tema da “Administração Estratégica de Recursos Humanos”, especialmente orientado para os profissionais de níveis operacional e administrativo no setor hoteleiro.

De acordo com referências bibliográficas que foram analisadas, a gestão de pessoas se torna, cada vez mais, compreendida como a área que deve estar diretamente relacionada à gestão estratégica de uma empresa, visto que sua sobrevivência no mercado globalizado (cujas demandas implicam em constantes transformações, e o setor hoteleiro se insere no mercado do Turismo, caracterizado por dimensões que se estendem para o cenário global), dependerá, exclusivamente, do desempenho profissional das pessoas que nelas se inserem. $\mathrm{O}$ ideal da adoção de estratégias e inovações ao trabalho baseia-se em orientar e definir diretrizes para que os esforços humanos, em uma empresa, se concentrem na realização das metas estabelecidas. Esse princípio se aplica no contexto de que proprietários e investidores, quando decidem pela criação e desenvolvimento de um negócio hoteleiro, objetivam obter 
lucros; o que só é possível de se alcançar através do bom desempenho organizacional - o sucesso - de um hotel, enquanto empresa compreendida por equipes de funcionários, cujas tarefas, contribuições e desempenhos devem ser devidamente administrados.

Deste modo concluiu-se que embora se constate a consolidação da perspectiva de que a área de Gestão de Pessoas apresenta consideráveis contribuições à obtenção dos melhores resultados no trabalho desenvolvido em uma organização, tal concepção ainda pode ser melhor adotada pelos gerentes gerais dos hotéis pesquisados, tendo em vista que atrair, capacitar e valorizar o capital humano de um hotel podem ser fatores determinantes para diferenciais estratégicos e vantagens competitivas no mercado do Turismo. 


\section{REFERÊNCIAS BIBLIOGRÁFICAS}

ACERENZA, M. A. Administração do turismo. Bauru: EDUSC, 2002

ANDRADE, N.; BRITO, P. L. Hotel: planejamento e projeto. São Paulo: SENAC, 2000

ARBACHE, J. S. O mercado de trabalho na atividade econômica do turismo no Brasil. Brasília: Editora da Universidade de Brasília, 2001

BORGES-ANDRADE, J. E. Avaliação integrada e somativa em TD\&E. In: BORGESANDRADE, J. E; ABBAD, G. S.; MOURÃO, L. (e cols.). Treinamento, Desenvolvimento e Educação em Organizações e Trabalho: fundamentos para a gestão de pessoas. Porto Alegre; Artmed, 2006

BRASIL. MINISTÉRIO DO TURISMO. Turismo sustentável e alívio da pobreza no Brasil: reflexões e perspectivas. Brasília, 2005

CASTELLI, G. Administração Hoteleira. Caxias do Sul: EDUCS, 2001

CERTO, S. C.; PETER, J. P. Administração estratégica: planejamento e implantação da estratégia. São Paulo: Pearson Prentice Hall, 2005

CERVO, A. L.; BERVIAN, P. A.; DA SILVA, R. Metodologia científica. São Paulo: Pearson Prentice Hall, 2007

CHIAVENATO, I. Gestão de pessoas: o novo papel dos recursos humanos nas organizações. Rio de Janeiro: Campus, 1999

CRUZ JÚNIOR, A. T.; CARVALHO, M. M. Obtenção da voz do consumidor: estudo de caso em um hotel ecológico. Revista Produção, v.13, n.3, p.88-101, 2003

DAVIES, C. A. Cargos em hotelaria. Caxias do Sul: EDUCS, 2001

FAISSAL, R.; PASSOS, A. E. V. M.; MENDONÇA, M. C. F.; ALMEIDA, W. M. C. Atração e seleção de pessoas. Rio de Janeiro: Editora FGV, 2005

FELIPPE, M. I. Identificação das necessidade de treinamento por competência In: BOOG, G. G.; BOOG, M. T. (coord). Manual de treinamento e desenvolvimento: processos e organizações. São Paulo: Pearson Prentice Hall, 2006

FERNANDES, E. Qualidade de vida no trabalho: como medir para melhorar. Salvador: casa da Qualidade Editora Ltda, 1996.

FREITAS, M. E. Cultura Organizacional: grandes temas em debate. Revista de Administração de Empresas, São Paulo, v.31, n.3, p.73-82, Jul/Set 1991

GAVA, R.; SILVEIRA, T. A orientação para o mercado sob a ótica da empresa e dos clientes na indústria hoteleira gaúcha. RAC, v.11, n.2, p.49-69, abr/jun 2007 
GIL, A. C. Gestão de Pessoas: enfoque nos papéis profissionais. São Paulo: Atlas, 2006

GONDIM, S. M. G.; BASTOS, A. V. B.; BORGES-ANDRADE, J. E.; MELO, L. C. T. Práticas inovadoras em gestão de produção e de pessoas e TD\&E. In: BORGESANDRADE, J. E.; ABBAD, G. S.; MOURÃO, L. (org.). Treinamento, Desenvolvimento e Educação em Organizações e Trabalho: fundamentos para a gestão de pessoas. Porto Alegre: Artmed, 2006

HAYES, D. K.; NINEMEIER, J. D. Gestão de operações hoteleiras. São Paulo: Pearson Prentice Hall, 2005

KAPLAN, R. S.; NORTON, D. P. Organização orientada para a estratégia. Rio de Janeiro: Elsevier, 2000

LIMONGI-FRANÇA, A. C.; ZAIMA, G. Gestão de Qualidade de vida no trabalho - GQVT in: Manual de Gestão de Pessoas e Equipes: Estratégias e tendências. São Paulo, 2004

LOBATO, D. M.; FILHO, J. M.; TORRES, M. C. S., RODRIGUES M. R. A. Estratégia de empresas. Rio de Janeiro: Editora FGV, 2007

LOBIANCO, M. M. L.; RAMOS, A. S. M. Gestão da Informação: uso da Internet no setor de hotelaria de Recife-PE. RAE eletrônica, v.3, n.2, Art 16. jul/dez 2004

MILIONI, B. O processo de T\&D In: BOOG, G. G.; BOOG, M. T. (coord). Manual de treinamento e desenvolvimento: processos e organizações. São Paulo: Pearson Prentice Hall, 2006

MARRA, J. P. Administração de recursos humanos: do operacional ao estratégico. São Paulo: Futura, 2000

MINTZBERG, H.; AHLSTRAND, B.; LAMPEL, J. Safári de Estratégia: um roteiro pela selva do planejamento estratégico. Porto Alegre: Bookman, 2000

MOTTA, P. R. Transformação Organizacional. A Teoria e a Prática de Inovar. Rio de Janeiro: Qualitymark, 1998.

NAVARRO, R. C.; POMI, R. M. Indicadores em educação e aprendizagem In: BOOG, G. G.; BOOG, M. T. (coord). Manual de treinamento e desenvolvimento: processos e organizações. São Paulo: Pearson Prentice Hall, 2006

PETROCCHI, M. Hotelaria: planejamento e gestão. São Paulo: Futura, 2002

PILATI, R.; BORGES-ANDRADE, J. E. Construção de medidas e delineamentos em avaliação de TD\&E. In: BORGES-ANDRADE, J.E; ABBAD, G.S.; MOURÃO, L. (e cols.). Treinamento, Desenvolvimento e Educação em Organizações e Trabalho: fundamentos para a gestão de pessoas. Porto Alegre; Artmed, 2006

PIMENTA, M. A. Gestão de pessoas em turismo: sustentabilidade, qualidade e comunicação. Campinas: Alínea, 2006 
ROBBINS, S. Administração: Mudanças e Perspectivas. São Paulo: Saraiva, 2000.

ROSS, G. F. Psicologia do turismo. São Paulo: Contexto, 2002

RUSCHMANN, D. V. M. Turismo e planejamento sustentável: a proteção do meio ambiente. Campinas: Papirus, 1997

RUTHERFORD, D. G. Hotel: gerenciamento e operações. São Paulo: Rocca, 2004

SILVA, N; ZANELLI, JC. Cultura organizacional, in: ZANELLI, J. C.; BORGESANDRADE, J. E; BASTOS, A. V. B. Psicologia, Organizações e Trabalho no Brasil. Porto Alegre: Artmed, 2004

TEIXEIRA, G. M.; SILVEIRA, A. C.; NETO, C. P. S. B.; OLIVEIRA, G. A. Gestão estratégica de pessoas. Rio de Janeiro: Editora FGV, 2006

ULRICH, D. Os campeões de recursos humanos: inovando para obter os melhores resultados. São Paulo: Futura, 1998.

WOOD JR, T. Mudança Organizacional: Introdução ao Tema. In: WOOD JR, Thomaz (org.). Mudança Organizacional. São Paulo: Atlas, 1995. p.15-31.

ZANELLI, J. C.; SILVA, N. Interação humana e gestão: a construção psicossocial das organizações de trabalho. São Paulo: Casa do Psicólogo, 2008

ZAVAGLIA, T. Gestão de Pessoas: desafios, tendências e expectativas. Campinas, SP: Editora Alínea, 2006 


\section{APÊNDICES}

APÊNDICE A - Questionário utilizado para coleta de dados

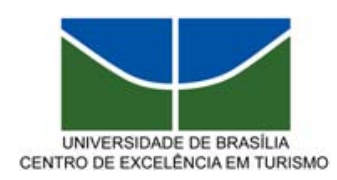

Universidade de Brasília

Centro de Excelência em Turismo

Curso de Especialização lato sensu Gestão de Negócios em Turismo III

Questionário para Pesquisa de Campo

PRÁTICAS DE GESTÃ O DE PESSOAS NO SETOR HOLETEIRO DE JUIZ DE FORA - MG

Aplicação com GERENTES GERAIS de hotéis juizforanos

Hotel:

Data: / Maio / 2009

Gerente:

Contato: (32)

e-mail:

1) Qual é a classificação do seu hotel, na perspectiva dos serviços de hospedagem que oferece?

( ) 1 estrela;

( ) 2 estrelas;

( ) 3 estrelas;

( ) 4 estrelas;

( ) 5 estrelas;

( ) Não há definição quanto à classificação desse hotel;

( ) Não sei.

2) Existe, no hotel gerenciado pelo(s) senhor(a), um departamento - ou setor próprio para práticas da área de Administração de Recursos Humanos, ou Gestão de

3) Pessoas ?

$\begin{array}{ll}\text { ( ) } & \text { Sim; } \\ \text { ( ) Não; } & \text { Não sei. }\end{array}$

2.1) Se "sim", as atividades desse departamento - ou setor - se concentram em:

( ) controle e fluxo documental para registros de Departamento Pessoal (folhas de pagamento, controle de faltas e atestados médicos, admissão e rescisão de contrato);

( ) procedimentos simples, com exclusividade em recrutamento e seleção de pessoas;

( ) processos elaborados, como descrição de cargos para definição e ajustes salariais por categoria profissional, determinação de planos de carreira e identificação de necessidades de treinamento e desenvolvimento (T\&D);

( ) Programas estratégicos, como aplicação de pesquisas de lima para diagnóstico organizacional, intervenções à melhoria contínua, mapeamento e gestão de competências, além de criação e implantação de programas de qualidade de vida no trabalho. 
4) Geralmente, os processos de recrutamento e seleção no hotel onde o(a) senhor(a) trabalha, são:

( ) desenvolvidos pelos próprios gerentes dos departamentos - ou setores solicitantes;

( ) realizados pela própria equipe de $\mathrm{RH}$ - ou de Gestão de Pessoas;

( ) prestados por terceiros, a exemplo de consultorias, ou por agências de empregos;

( ) não ocorrem processos seletivos nesse hotel.

( ) Não sei.

5) Existem oportunidades para os hoteliers de sua organização desenvolverem plano de carreira?

( ) Não;

( ) Sim, periodicamente são realizados recrutamentos internos;

( ) Sim, de acordo com desempenhos que se destacam;

( ) Sim, de acordo com planejamentos do departamento - ou setor - de RH - ou Gestão de Pessoas;

( ) Não sei.

6) Os hoteliers dessa organização recebem treinamentos?

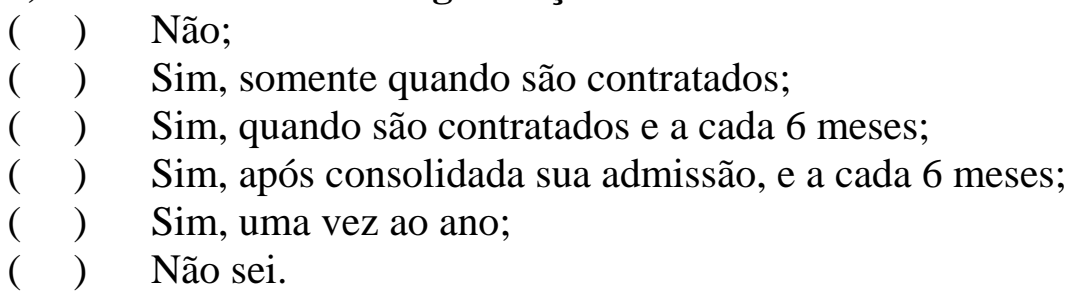

7) Os programas de T\&D, direcionados aos profissionais desse hotel, geralmente são:

( ) Não há programas de T\&D nesse hotel;

( ) Realizados no próprio espaço físico do hotel (treinamento on job), ministrados por especialistas contratados;

( ) Realizados no próprio espaço físico do hotel (treinamento on job), ministrados pelos próprios funcionários efetivos, cujos talentos se destacam;

( ) Ministrados em estruturas próprias para esses programas, como SENAC, conselhos de turismo e hotelaria, ou sindicatos;

( ) Não sei.

8) São aplicadas avaliações de desempenho nesse hotel?

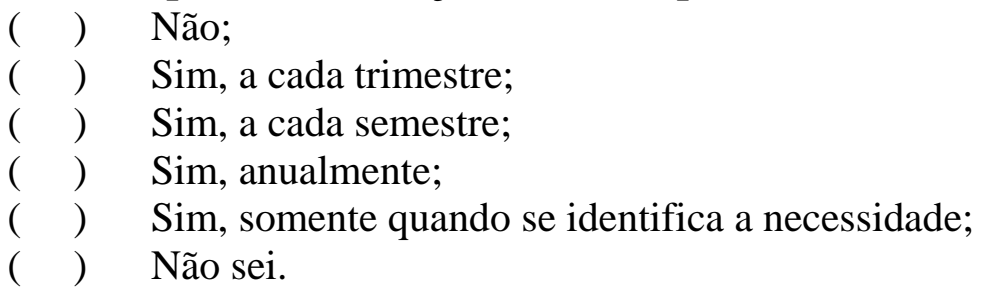

9) As práticas de Gestão de Pessoas, no hotel pesquisado, são orientadas de acordo com uma descrição de cargos, já desenvolvida?

( ) Não há nenhuma descrição de cargos devidamente formalizada nesse hotel;

( ) Sim;

( ) Não sei. 
10) Existem ferramentas para a mensuração da qualidade na prestação de serviços oferecidos nesse hotel?

( ) Sim, são aplicadas pesquisas de satisfação/opinião dos hóspedes atendidos;

( ) Sim, são aplicadas pesquisas de motivação dos hoteliers;

( ) Sim, através da observação direta e avaliação dos serviços prestados;

( ) Sim, através de outros meios;

( ) Não;

( ) Não sei.

\section{1) Na sua perspectiva:}

( ) A gestão de pessoas assume caráter estratégico ao colaborar para o sucesso do hotel;

( ) A área de Gestão de Pessoas, nesse hotel, pode colaborar mais para o seu bom desempenho organizacional;

( ) Existem outras áreas administrativas mais importantes do que a Gestão de Pessoas;

( ) A Gestão de Pessoas é indiferente para a determinação de diferenciais estratégicos do hotel sobre seu mercado;

( ) Não sei opinar sobre a Gestão de Pessoas no hotel onde trabalho. 


\section{APÊNDICE B - Modelo de e-mail enviado aos hotéis}

Apresenta-se, neste apêndice, o modelo de e-mail que o pesquisador enviou para os vinte e quatro endereços de correio eletrônico de representantes do universo que compõe o setor hoteleiro de Juiz de Fora - MG:

\section{Assunto: Realização de Pesquisa sobre Gestão de Pessoas em Hotéis Juizforanos}

Terça-feira, 16 de Maio de 2009 11:07

De: "Fred Alvim" < fredalvim@yahoo.com.br>

Exibir informações de contato

Para: reisafat@hotmail.com

A mensagem contém anexos: Questionário para Pesquisa de Campo.doc (163 KB)

Prezados(as) Gerentes,

Venho, por meio deste, solicitar a sua participação, enquanto representante do hotel em que o(a) senhor(a) trabalha, para obter informações referentes, exclusivamente, às práticas de Gestão de Pessoas na referida organização. Sua colaboração é condição essencial à realização da Pesquisa "PRÁTICAS DE GESTÃO DE PESSOAS NO SETOR HOTELEIRO DE JUIZ DE FORA - MG”, trabalho que estou realizando como atividade de conclusão do curso de pós-graduação lato sensu de Gestão de Negócios em Turismo, promovido pelo Centro de Excelência em Turismo da Universidade de Brasília.

Assim sendo, solicito ao(a) senhor(a) o preenchimento do questionário em anexo e posterior envio do mesmo, respondido, para esse e-mail. Caso prefira estabelecer contato pessoal, por favor, solicito a resposta desse e-mail informando horário e data em que possa visitar o hotel onde o(a) senhor(a) trabalha. Porém, enfatizo que é extremamente importante a sua participação nesse estudo.

Para o desenvolvimento desta pesquisa, faz-se necessária a aplicação de um breve questionário (composto por 10 perguntas) a ser aplicado com gerentes gerais dos hotéis juizforanos, de modo a possibilitar conhecer como esses gerentes concebem as práticas de Gestão de Pessoas nas organizações que gerenciam.

Vale ressaltar que as 10 questões que estruturam o questionário foram elaboradas de modo a não gerar nenhum tipo de constrangimento, tampouco qualquer necessidade de omissão. Além disso, e mais importante: as informações obtidas serão tratadas na pesquisa sob caráter de sigilo, de modo que nenhum dado será especificado por gerente/hotel que tenha fornecido tais informações. Os dados serão trabalhados sob critérios estatísticos de análise do universo investigado (24 hotéis de Juiz de Fora).

Caso seja de seu interesse, posso disponibilizar o projeto — onde são detalhados objetivos e justificativas para a realização dessa pesquisa — ou, até mesmo, apresentar os resultados finais desse estudo, quando estiver concluído, e de acordo com programação (definição de data, horário e local) determinada pelo(a) senhor(a).

Desde já, muito obrigado pela atenção e colaboração,

$\underline{\text { Frederico Azevedo Alvim Assis }}$

Pesquisador

e-mail: fredalvim@yahoo.com.br

tel.: (32) 8845-1615 


\section{ANEXOS}

\section{ANEXO A: E-mails enviados}

E-mail recebido da associação Juiz de Fora e Região Convention \& Visitors Bureau, em resposta à solicitação de auxílio para o desenvolvimento desta pesquisa:

ASSUNTO: Re: Solicitação de auxílio para desenvolvimento de pesquisa

Quinta-feira, 14 de Maio de 2009 18:10

De:

"JFRC\&VB - Juiz de Fora e Região Convention" <jfrcvb@juizdeforaconvention.com.br> Adicionar remetente à lista de contatos

Para:

"Fred Alvim" <fredalvim@yahoo.com.br>

Prezado Frederico,

Boa tarde!

Conforme conversado ontem com você, passamos para a nossa diretoria a questão sobre a carta de apresentação e a diretoria não nos autorizou fazer esta carta de apresentação. Mas de qualquer forma, repassaremos para você os contatos de quem você solicitou:

\section{CÉSAR PALACE HOTEL}

Email:reservas@cesarpalacehotel.com.br

CÉSAR PARK HOTEL

Email: reservas@cesarparkhotel.com.br

CHALÉS SAN THOMAZ ECORESORT

E-mail: recepcao.santhomaz@hotmail.com

CONSTANTINO HOTEL \& EVENTOS

Email: reservas@constantinohotel.com

GRANDE HOTEL RENASCENÇA

Email: eliseuvalle@yahoo.com.br

HOTEL DOS VIAJANTES

Email: leofbaraujo@yahoo.com.br

HOTEL FAZENDA ESTÂNCIA REAL

E-mail: reservas@hotelfazendaestanciareal.com.br

IMPERIAL HOTEL

Email:imperialhotel@uol.com.br

INTERNACIONAL HOTEL

Email: internacionalhotel@bol.com.br 
Email:joalpajf@terra.com.br

MAJESTIC COLONIAL HOTEL

Email:majestic@majesticjf.com.br

MAXIM PLAZA HOTEL

Email:max@maxplaza.com.br

ÔMEGA APART HOTEL

Email:omega@powerline.com.br

RITZ PLAZA HOTEL

Email:reservas@ritzplazahotel.com.br

ROBLEVILLE COMERCIAL HOTEL

Email:roblevillehotel@gmaol.com

SERRANO APART HOTEL

Email:apart@serranohotel.com.br

SERRANO RESIDENCIAL HOTEL

Email:serrano@serranohotel.com.br

SOLAR FLAT HOTEL

Email:falecom@solarflathotel.com.br

VICTORY BUSINESS HOTEL

E-mail:reservas@victoryhoteis.com.br/vendas@victoryhoteis.com.br

\section{VICTORY SUÍTES}

Email:vendas@victoryhoteis.com/reservas@victoryhoteis.com.br/

branco@victoryhoteis.com.br

SESC Pousada de Juiz de Fora - Centro de Turismo, Convenções e Lazer

Email: sescmgpj@uai.com.br

Pousada Aconchego de Minas

Email: aconchegodeminas@aconchegodeminas.com.br

Pousada Cidade Alta

Email: pousadacidadealta@orolix.com.br

Pousada e Restaurante Pepasi

Email: reisafat@hotmail.com

Atenciosamente,

Ana Laura Marendino 
J uiz de Fora e Região Convention \& Visitors Bureau

Em Juiz de Fora grandes atrações esperam por você!

www.juizdeforaconvention.com.br

NOVO ENDEREÇO: Av. Barão do Rio Branco, 2370 - Sala 1119 - Centro

(32) 3217-8766

Original Message -----

From: Fred Alvim

To: ifrcvb@juizdeforaconvention.com.br

Sent: Thursday, May 14, 2009 10:04 AM

Subject: Solicitação de auxílio para desenvolvimento de pesquisa

De: Frederico Azevedo Alvim Assis

A/C: Gerência Executiva

Convention \& Visitors Bureau

Olá Patrícia Gonçalves,

Conforme contato estabelecido ontem (13 de maio de 2009), envio esse e-mail para oficializar minha solicitação de auxílio ao desenvolvimento de minha pesquisa PRÁTICAS DE GESTÃO DE PESSOAS NO SETOR HOTELEIRO DE JUIZ DE FORA-MG, trabalho que estou realizando como atividade de conclusão do curso de pós-graduação lato sensu de Gestão de Negócios em Turismo, promovido pelo Centro de Excelência em Turismo da Universidade de Brasília.

Para o desenvolvimento desta pesquisa, foi definido como instrumento para coleta de dados um questionário fechado (composto por 10 questões) a ser aplicado com gerentes gerais dos hotéis juizforanos, de modo a possibilitar conhecer como esses gerentes concebem as práticas de Gestão de Pessoas nas organizações que gerenciam. O objetivo da referida pesquisa centra-se em descrever quais são as atividades de Gestão de Pessoas realizadas para promoverem o diferencial estratégico da organização hoteleira, de modo a identificar contribuições estratégicas da Gestão de Pessoas para a prestação dos serviços de hospedagem, analisar a importância do planejamento dessa área e comparar as principais práticas vigentes com as propostas e conteúdos pesquisados na literatura.

Todavia, me deparei com impossibilidades ao tentar estabelecer contato com os gerentes de alguns hotéis visitados. Com isso, solicito à Convention \& Visitors Bureau a elaboração e emissão de uma "Carta de Apresentação" que me possibilite estabelecer contato com aqueles gerentes para aplicação de questionário, e/ou a relação de e-mails de gerentes dos 28 hotéis juizforanos, de modo a possibilitar efetivar a referida aplicação do questionário através de correio eletrônico.

Vale ressaltar que as 10 questões que estruturam o instrumento para coleta de dados foram elaboradas de modo a não gerar nenhum tipo de constrangimento, tampouco qualquer necessidade de omissão. Além disso, e mais importante: as informações obtidas serão tratadas na pesquisa sob caráter de sigilo, de modo que nenhum dado será especificado por gerente/hotel que tenha fornecido tais informações. Os dados serão trabalhados sob critérios estatísticos de análise do universo investigado (28 hotéis de Juiz de Fora). De todo modo, envio o questionário em anexo.

Desde já, muito obrigado pela atenção e disponibilidade de auxílio ao desenvolvimento de minha pesquisa.

Att,

Frederico Azevedo Alvim Assis 